
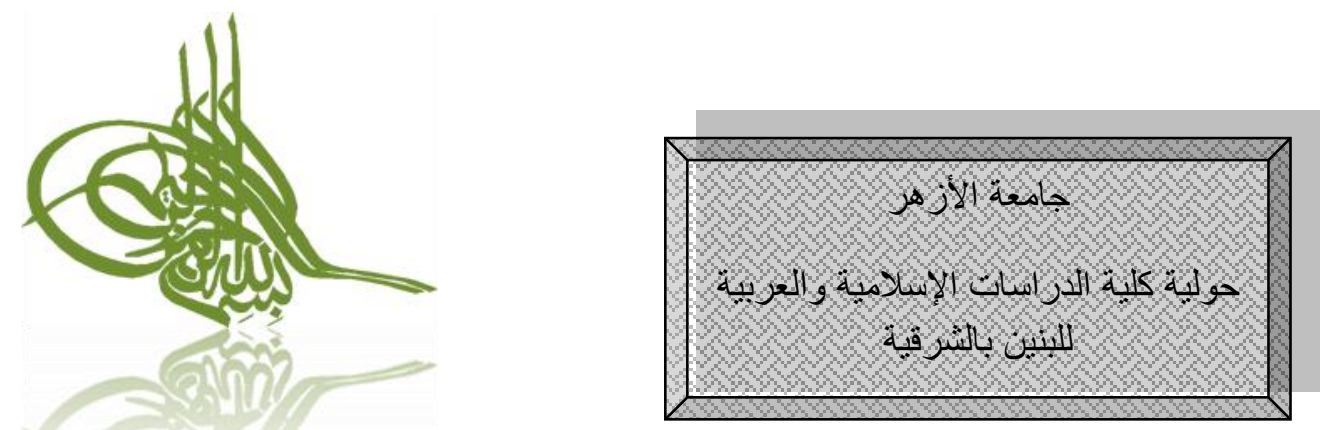

مِنْ تَِّّلِات الخِطَاب الصُوِّفي عند شعراء الأزهر النصف الثانسي من القرن العشرين

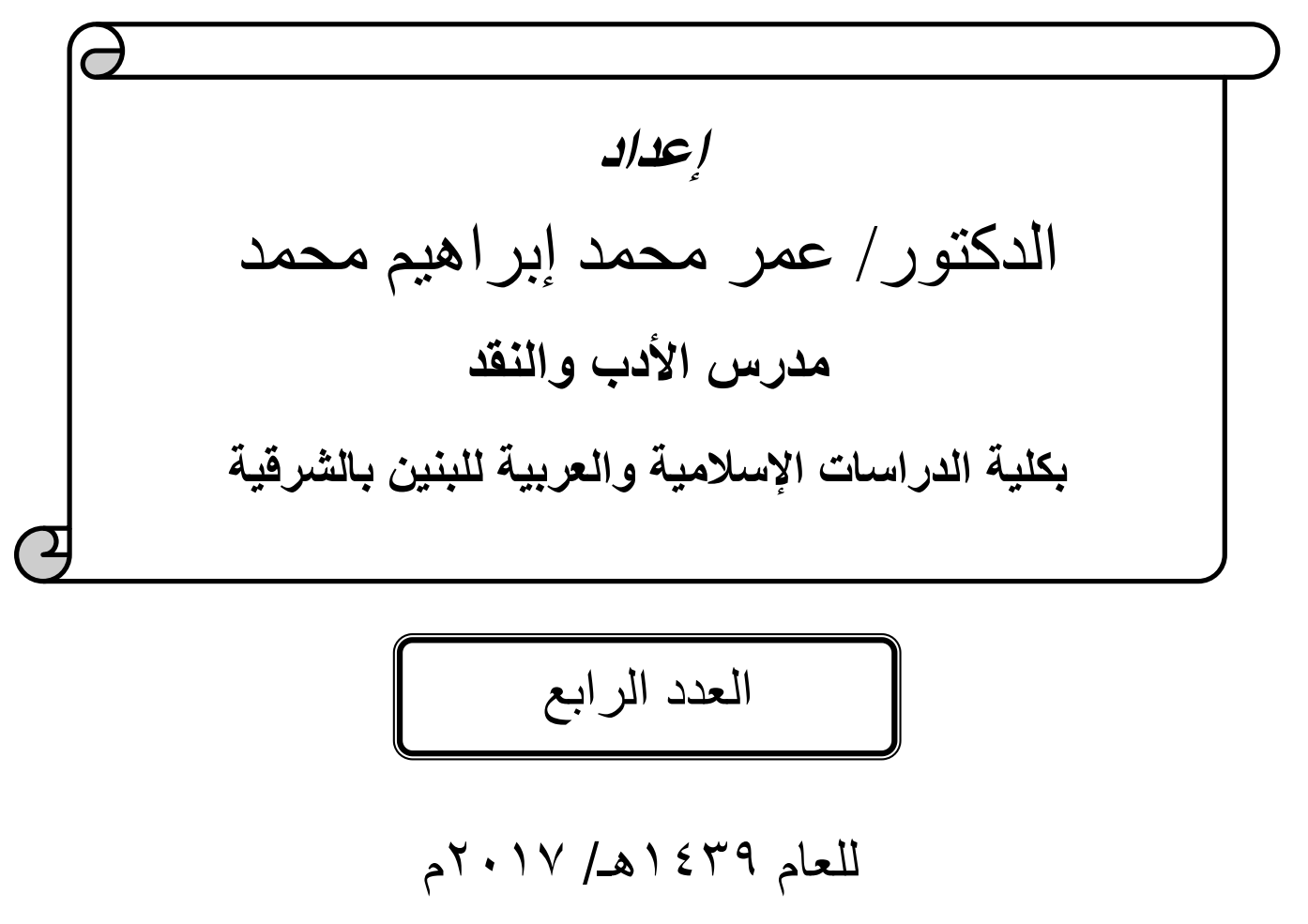





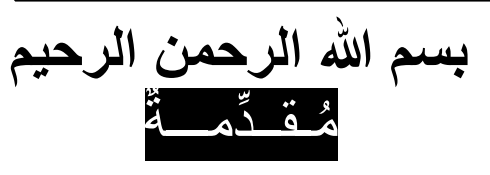

الحمد لله رب العالمين ، والصلاة والسلام على سيٍّ الأولين

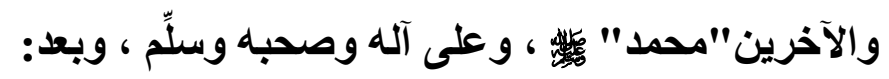

فَإنَّ مِن أبرز أسباب تسمية الشَّعر شِعْرًا هو تعبيره عن الشُّعور الصادق ، والكثف عما يَجُول في الخواطر ، وسنبَر أغوار النفوس، دون تكلُّف أو تصنُّع ـغالبًا- وهو ما يُسمى بالثعر الصادق ؛ ولذلك كاتت هنالك صِلَات قرابة وعوامل تثابه بين التصؤف والشعر، فكلاهما وثيق الصلة بالعاطفة والرُوح والوجدان، فضلَ على إيثار الرمز، والتلميح، على الوضوح والتصريح ، مع اعثمادهما على الخيال والإلهام ، والحس والتنبُؤ بالمصير؛ ولهذا كان الثعر هو الوعائُ الرئيسُ الأي استَّبّل المعاني الصوفية، وكان أمينًا على نقل وتوثيق تجاربهم ومَقامَاتهم وأحوالهم وَوَسطيَّتهم وشَطَطِهم، كما في أشعار" رابعة العدوية "، و

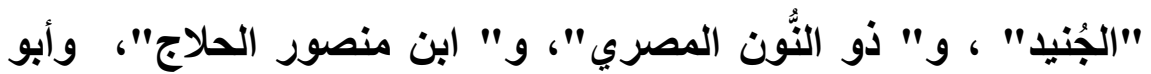
حفص بن الفارض "، و " محي الاين بن عربي" ، وغيرهم .

وقد شارك شعراءُ الأزهر أقرانَهم من الشعراء في خوض تلك

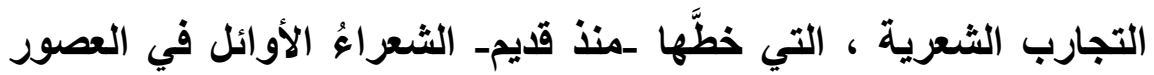
الغابرة، فالفكر الصوفي الإسلامي- بمعناه الشامل- عميقٌ مُتأصلّ في وجدان مُعظم شعراء الأزهر وفِكرهم ؛ بما لهم من مرجعيةٍ دينيةٍ متعمقةٍ

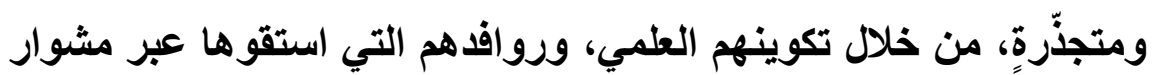
حياتهم، فلا غرو-إذن- أن نجد في منجزهم الإباعي قصائد ذات حمولاتٍ 
تأمليَّة ، ونزعاتٍ رُوحيَّة، وَوَمضاتٍ نور انيَّة؛ نتيجة ثقافةٍ إسلاميَّةٍ واسعة، وأزهريةٍ مُتشبعة، وشاعريَّة مُتدفقة .

كاتت هذه التجارب الشعرية الرائدة ـ في هذا المجال وغيره ـ لترد على كلّّ من ينكر دور الأزهر في النهضة الأدبية قديمها وحديثها، أو زَغْم عجزه عن التعبير عن روح العصر ومتطلبات الواقع ، فضلً عن قدرته على التعبير عن الذَّات وخلجات النفس ومر آة الثعور.

فللأزهر مجد راسخْ تليدٍا، وجهٍِ أكيدٍ في بناءع الحضارة وبعث التهضة الأدبية التي يتفاخر بها الثرق على الأمم الأخرى، هذا المجد وتلك المنزلة ينبغي الحفاظ عليها والاعتزاز بها في وقتٍ "تثتثُّ عليه حملةٌ ممنهجةٌ ومنظمةٌُوموجهةٌ، يريد أصحابها حِرمان الأمَّة مِن جهوده، العظيمة" (1)، التي لا يُنكر ها إلا جاحد.

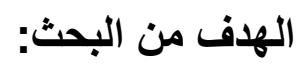

ولهذا حاولتُ الأَّود عن حِياض الأزهر وشعرائه من هذه الزاوية ؛ فكان عنوان البحث:"من تجليَّات الخطاب الصوفي عند شعراء الأزهر في النصف الثاني من القرن العشرين"؛لأستخرج-من خلال خُطته التفصيليةـ وَسَطِيَّةَة غالب شعراء الأزهر، وتلمُّس حضور نزعتهم الصوفيَّة، ومقارعتهم للماديَّة المَقِيتة، ودعوتهم إلى التأمُّل في الكون والنفس، والتحريضِ على الطُّر والعفاف، والحثٌّ على الزّهُهد الحقيقي والورع

(') الغارة المثبوهة على التعليم الأزهري، د. محمد عمارة ، صبهه، دار المقاصد، طا،

$$
\text { . }
$$


الصادق، والتَّرُّف على الخالقَ-جلَّ وعلا- ودلالة الخَلْق عليه، ودعوة الناس إليه ، وتحْبير مدائحهم النبوية، والتعبير عن أشواقهم الحجازيَّة، وغيرها من اللآلَئ المنثورة في ثنايا أشعارهم، والَّرر العالقة في مَكْنون مفرداتهم، وجماليَّات تراكيبهم وصورهم وأخيلتهم، وما أودعوه في قصائدهم من عَتَباتٍ مبثوثة، ونصوصٍِ مُوازية مقصودة، والتي تنبض

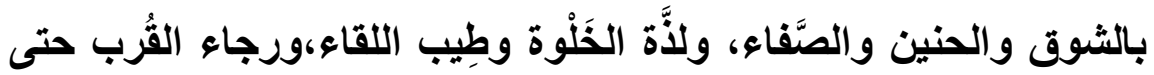
الفناء، والابتهال والمناجاة ، وإدراك سرِّ الوجود ، ومعرفة كُنْه الحقيقة، عبر الإشارة والرَّمز تارة، أو التمطيط والإطناب تارةً أخرى،وقد شهدت هذه المدة الزمنية_ مدة البحث_تجرؤ العدو على مصر-والعالم الإسلامي-في

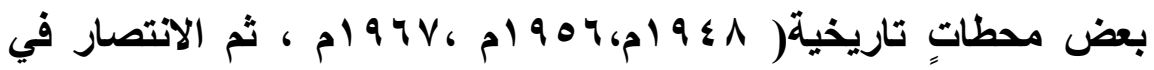
رمضان (ب q ج اه)، وما بعدهم من أحداثٍ ؛ فلجأ الشاعر الأزهري- بسببٍ من ذللك- إلى السَّماء ، مُستشفقعًا بسيِّ الخلق ، داعيًا قومَه إلى اللجوء إلى الله، والتحلي بمكارم الأخلاق ؛ علَّها ترفع عنهم ما حلَّ بهم .

ومن هؤلاء الشعراء الذين كان لهم القِّحح المُعلَّى في هذا الاتجاه('): ( الثاعر الشيخ " محمد متولي الشعراوي" ، والشاعر الاكتور"حسن جاد" والشاعر الاكتور " محمد عبد المنعم خفاجي"، الثاعر الثيخ "محمود أحمد محمود هاثم" ، الثاعر "عبد الله شمس الاين" ، والثاعر الاكتور"محمد رجب البيومي"، الثاعر الدكتور"محمد عبد المنعم العربي" ، والثاعر الدكتور "محمد أحمد العزب" الشاعر"هاشم الرفاعي" ، الثاعر الدكتور"عبد الغفار حامد هلال" ، والثاعر

(1) مرتبةً حسب تاريخ الميلاد ، وسيأتي التعريف بهم - بإذن اللهـ في ثنايا البحث .

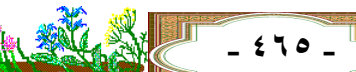


الدكتور "أحمد عمر هاشم" ، والشاعر الاكتور"صابر عبد الدايم)،

وغيرهم من الشعراء مما لا يتسع المجال لِإِكْرهم .

خطة البحث:

وقد اشتمل البحث على نبذة عن التصوف وعلاقته بالشعر، ثم مبحثين :

الأول عنوانه : تجليات الخطاب في الاتجاهات والأغراض ، وفيه

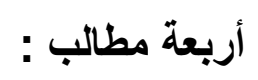

المطلب الأول: مناجاة الله والحب الإلهي .

المطلب الثاني: المدائح النبوية والأماكن المقدة .

المطلب الثالث : الدعوة إلى الفضائل ومكارم الأخلاق

المطلب الرابع: حقيقة النفس والارتقاء بها .

أما المبحث الثاني فجاء تحت عنوان : السِّمات القنيَّة في الخطاب الصُّوفي عند شعراء الأزهر، وفيه ثثلاثة مطالب:

المطلب الأول: تجليَّات الخطاب في اللغة والأسلوب.

المطلب الثاني: تجليَّات الخطاب في العَتَبَاتِ والنصِّ المُوازي.

المطلب الثالث: تجليّّات الخطاب في الموسيقى والإيقاع .

ثم أردفتُه بخاتمـة، أودعتُ فيها أهم النتائج والتوصيَّات، ثم ثَبَتُّ

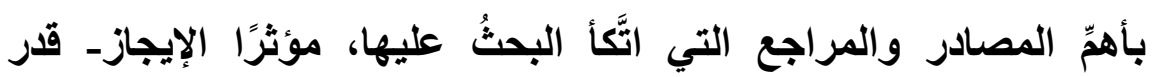


المستطاعـ ليتناسب وطبيعة البحث؛ فما هو إلا خطوة على الطريق، وقَطْرُ

$$
\text { يتبعه - بإذن الله- غيثٌ. }
$$

واللهَ أسألُ أن يَتْفع به في الدنيا والآخرة، وأن يكون محاولةً في الوقوف_من خلال الشُّعر - على التصوف الصحيح الذي يُزوِّد المؤمن بقيمٍ رُوحية عُلْويَّة تُعينه على جفاء الماديَّة ، ولأْوَاء الحياة ، وكذلك للتعريف بثعراء الأزهر ومُبدعيه ، وإلقاء الضوء عليه؛ كي يسبر الباحثّن أغورَاه من جوانبه المتعددة ؛ اعترافًا بالفضل، وردًا للجميل. والحمد لله رب

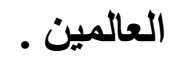

\section{الباحث :}

عمر محمد إبراهيم محمد

$$
\text { مدرس الأدب و النقد }
$$

في كلية الدر اسات الإسلامية و العربية بنين بالشرقية

تُبْذة عن التصوف وعلاقته بالثعر

أولًا": تعريفت بالتصوف: 
تعددت الأقوال في سبب التسمية، فمنهم من قال بأنه من لِبْس

الصوف، ومنهم من قال:مأخوذ من الصفاء والنقاء، ومنهم من قال: نسبة

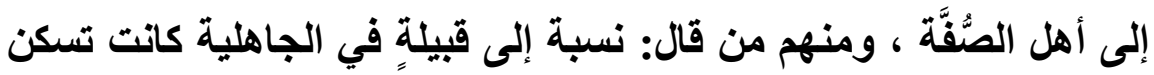

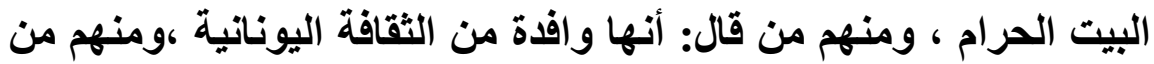
قال من الصَّف؛ لأن الصوفية في الصف الأول أمام الله جلَّ وعلا ، إلى فنى لهن غيرها من الأقوال والتأويلات (') ، وما يهمنا ـفي هذه البحث_هو أن التصوف الإسلامي بات عَلَمًا - غالبًا على حبّ الله وحُبّ نبيّه وآلِ بيته الكِرام ، والتأمل في النفس ومعرفة حقيقتها والارتقاء بها، والدعوة إلى لى

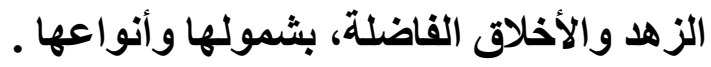

فبعد أن مضى عضُرُ الصحابة والتابعين وتابعيهم، وظهرتُ بدعُ

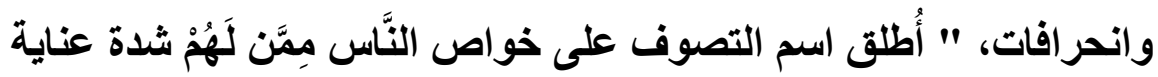

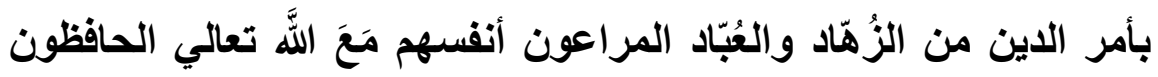
قلوبهم عَن طوارق الغقلة، واشتهر هذا الاسم لهؤلاء الأكابر قبل المائتين من الهجرة" (†)؛ ولهذا أطلق عليه الجرجاني: بأنه"صفاء المعاملة مع الله

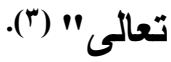

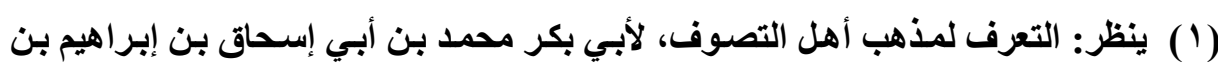

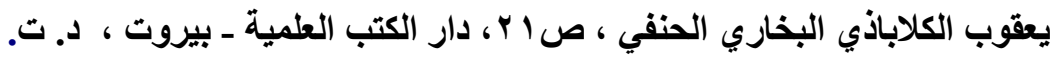

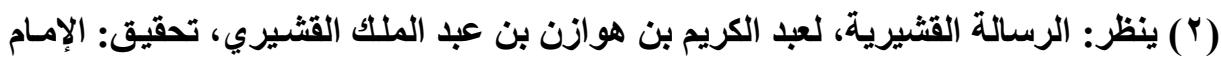

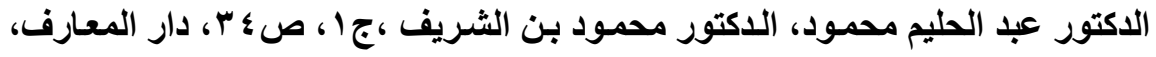

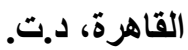

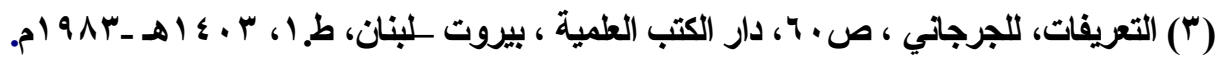

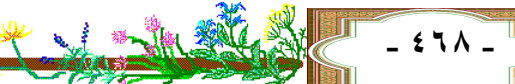


فهناك منطلق رئيسٌ للتصوف لا خلاف عليه ـغالبًا وهو ما سنسير عليه-بعون اللهـ في دراستنا، وهو حُبٌّ الله، والثوق إليه والأنس

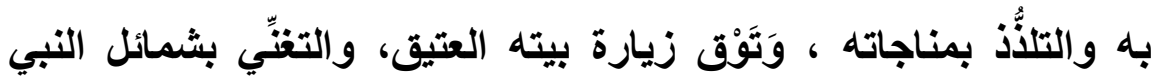
الكريم ومعجزاته الخالدة ، وَحُبِّ مدينته وقبره الشريف ، ورجاء شفاعته ، والتأمل في التفس والكون والحياة ، والتحلِّي بالفضائل، والتخلّي عن الرذائل، هذه الأخلاق التي هي الركيزة التي يُبنى عليها التصوُّف، وهو ما

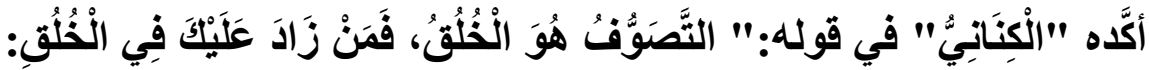

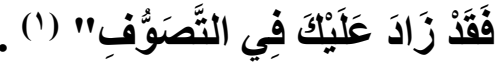
فليس التصوف الصحيح هروبًا من لأواء الحياة ومنعطفاتها، بل يعمل على التوازن والشموليةـــ وهما من خصائص التصور الإسلامي- في العلاقة بين العبد ورباه، وبين الإنسان ومجتمعه،وبذلك يسير التصوف في الاتجاه الإيجابي الصحيح،لا السلبي المُستكين ، التصوف المُقيَّبّ بالكتاب والسنة ، لا يبتداع في الدين ، ولا يُحْدث أمرًا ليس فيه ، ويوجز لنا " لئ الجنيد " ذلك بقوله :"عِلْمُنا هذا مُقِيَّة بالكتاب والسيُنة، أو بأصول الكتاب والسنة " () ، فيلتزم الصوفي ـالحق- بما جاء به الكتاب الكريم ، والسُّنة الصحيحة ، ويقتدي بالسابقين الأوَّلين ، قولَا وعملا . ثانيًا :علاقة الشَّعر بالتصوف:

( ( ) مدارج السالكين بين منازل إيلك نعبد وإيـاك نستعين، لابن القيم ، تحقيق: محمد المعتصم بالله

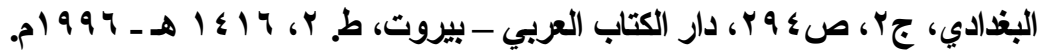

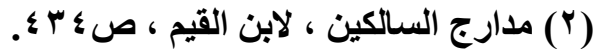


الثَِّعر منبعه الوجدان، يرتكز على الخيال والعاطقة، والصورة المُعبِّرة عن الفكرة، والرمز المُوحي؛ ولذلك اعتَّى الصوفيون- منذ قديمٍبالثعر، فهو يتلاقَى مع الستُعُو الرُوحيّ والتأمل الأي ينبثق منهما التصوف، والتي ينتج عنهما الإلهام؛ فالتفكر والتأمل بالوجدان والقلب: أبرز ما يُميِّز الشَاعر والمتصوِف على السنَّواء.

كما يتَّسمان-غالبَا- بصدق التجربة؛؛ كونهما ينبعان من معاناةٍ ومكابدة، وألٍْ وجوىً مُضْطرمِ في الوجدان، فكما قيل: "التصوف اضطراب ، فإذا وقع السكون فلا تصوُف"(') ، كما أن موضوعهما : الكثف عما وراء الواقع، والبحث عن المُطُلق، والانعتاق من الزمان والمكان إلى فضاءاتٍ أَرْحب ، وأُفُقِ أوسع ، عبر الحس والإلهام والخيال .

ويتفقان كذلك في اللغة، فلهماـفي الغالب- لغة خاصة ،" لغة الخصوص لا العموم، لغة المجاز والرمز لا لغة التصريح والوضوح ؛ فلغة العموم لا تفي-غالبًا-بالتعبير عن معانيهم، أو ضنَّا بما يقولون على من سواهم ، فالصوفي لا يُخرج مُعظم ما في داخله ؛ لأن من يريد أن يَعرف التجربة الصوفية: فعليه أن يذوقها، لا أن يعرفها "((') ، مَعرفةًَ مُجردةً غير محسوسة ، ولألك كان الرمز هو العنصر الرئيس الذي يُعتمد عليه في الغالب؛ لأنه مناسب للمعاني الروحية التي هي من أعمال القلوب، والتي لا

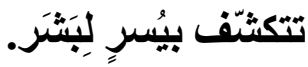

(1) طبقات الصوفية، لأبي عبد الرحمن السلمي ، تحقيق: مصطفى عبد القادر عطا،

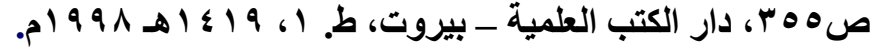

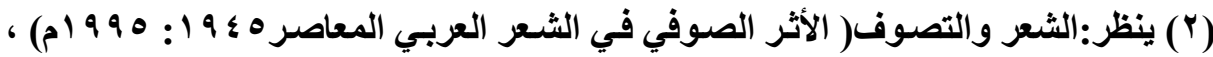

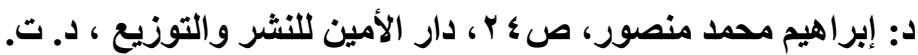


غير أن التجربة الصوفية تجربة داخلية وجدانية تحتاج لنَظٍْ

مَحفْوظٍ أو مدوَّن؛ كي يُخرج صاحبُها ما في أعماقه من معانٍ ورؤى ،

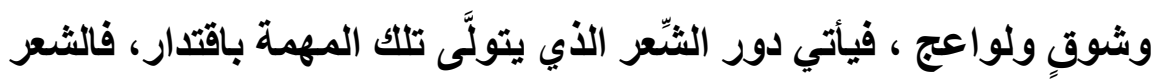
كفيلّ بالتعبير عن التجارب الإنساتية بعامة ، والتصوف بصفة خاصة ؛ " بوصفه استبطانًا مُنظًََّا لتجربةٍ روحيَّة، ومحاولة للكشف عن الحقيقة، والتجاوز عن الوجود الفعلي للأشياء" (') .

كما أن التجربة الشعرية (المادية) مرتبطة بالعنصر البشري في الغالب، أما التجربة الصوفية ، فموضوعها وجدانيٌٌ مَخض يدعو إلى الزهد والرقائق، مُتصلّ بالملأ الأعلى والذَّات الإلهية ، والثوق والثهو والحنين إلى كل

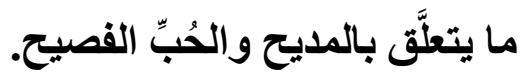

\section{المبحث الأول}

\section{تجليَّات الخطاب في الاتجاهات والأغراض}

عمد الأدب الصوفي الإسلامي- في القديم- إلى مقاومة آفاتٍ طرأت على المجتمع ؛ بسبب بُعد العُهر ، وطول الأَمَد، وقسوة القلوب، والانفتاح

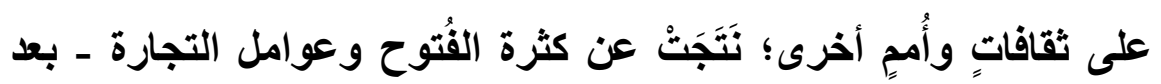

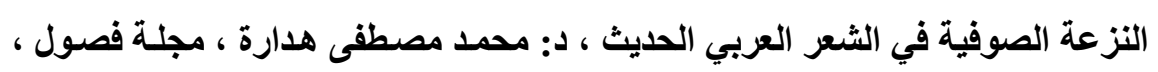

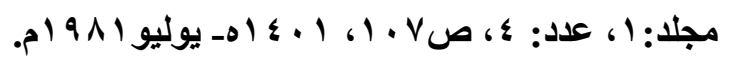


طول التزامِ وتماسلٍِ وانسجام في قَّْن الخَيْر الأوَّل- فطققوا يَقِرضون الشعر؛ ليتناسب وتللك الحالة الطارئة؛ فالأدب مرآة المجتمع، وهو ما فعله أدباء العصر الحديث عمومًا، وشعراء الأزهر على وجه الخصوص، فراحوا ينفضون عن الأمة غبار المادية، وقاوموا التغريب ، ليحافظوا على الهُويَّة ، وكانوا حائط صدٍ منيعِ ضد إزاحة الدّيّن عن الحياة ؛ لتتحقق الخيرية للأمَّة التي اصطفاها الله، كما أرادوا أن يُطبِّقوا هذه التجربة (الصوفية) تطبيقًا عمليّا؛ ليظهروا حقيقتها من غير إفراطٍ ولا تفريط ، ومن غير شططٍ ولا غلوٍ ولا انحراف، في الغالب الأعم، وقد ارتكزت دعائم الخطاب الصوفي عندهم على اتجاهات عدة، أبرزها :( مناجاة الله والحب الإلهي، الشوق إلى رسول الله والأماكن المُقدسة ، الدعوة إلى الفضائل ومكارم الأخلاق ، التعرف على حقيقة النفس الإنسانية ). المطلب الأول: مناجاة الله والحب الإلهي في البداية ينبغي القول: أن حبَّ الله-تعالى- وتعظيمه وتقليره، أمرّ محبِّ ومشروعٌ ؛ بَيْد أن الله سبحاتهـ قد أثنَى على عباده المؤمنين بأنهم " ...أَشدُّ حبّا لله... "(1)، وقد عاب على غيرهم بأنهم :".... مَا قََرُوا اللَّة حَقَّ قََْرِه..." (r)، وهو ما عبَّر عنه الشعراء في كل العصور من خلال

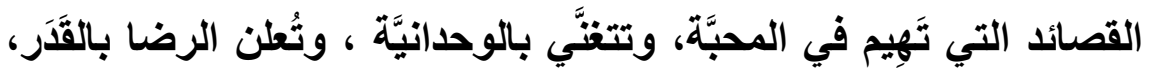

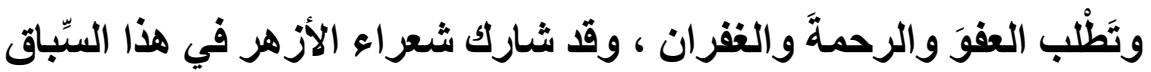
النُّوراني، عبر قصائد غُرر، وأبياتٍ يفوح منها عَبَقُ الشوق والحنين. 
وعلى سبيل المثال عند شعراء الأزهر، ما نجده عند الشاعر الدكتور" حسن جاد حسن"(') مستغرقًا في قصيدة صوفيَّة، أهداها إلى الثيخ "محمد متولي الشعراوي"(())، يقول منها: (البسيط)

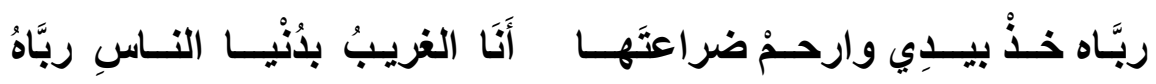

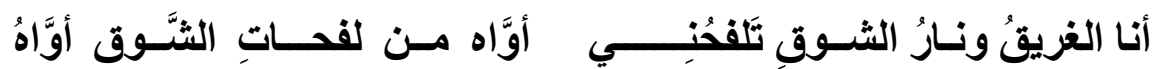

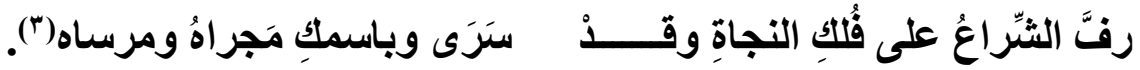
يتضرُع الثاعر إلى ربِّه، ويناديه في إلحاحِ ويقين،أن يشمله بعفوه، ويؤنسه من وحشته؛ هو غريبٌ في دنيا الناس، وعزاؤه أنه غريق في الحب الإلهي ، تلفحه أنوارُ الشوق والحنين، فيؤثر-إبَّان هذا الشعور- أن يستدعي المشهد الُكلّي لسفينة "نوح" الناجية ، وهو رمزٌ كليُ متنامٍ في نصِّ واحد، ساعده على ذلك عناصر أسلوبية لتكتمل هذه اللوحة المُفعمة بالاسترحام والتضرع كالتداء والتكرار والتناص الاقتباسي مع بعض نصوص القرآن الكريم ، فهو وإذا كان موشكًا على الغرق إلا أنه

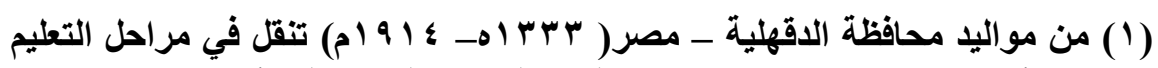

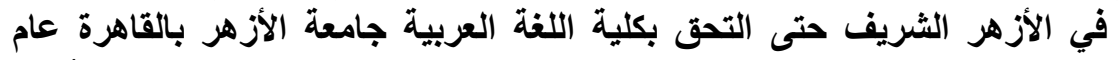

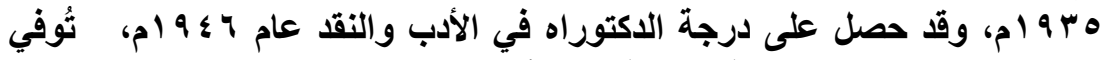

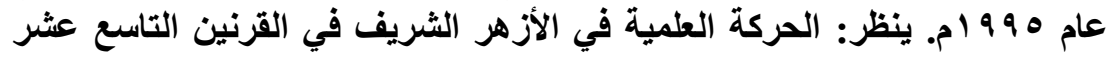

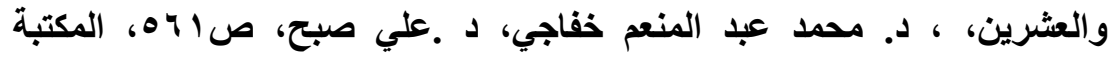

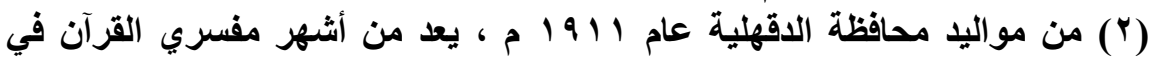

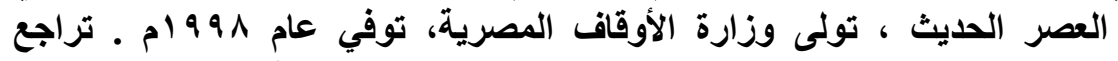

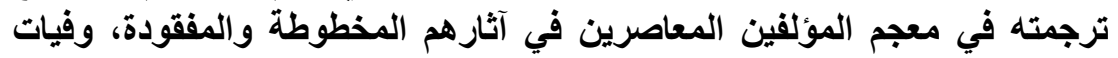

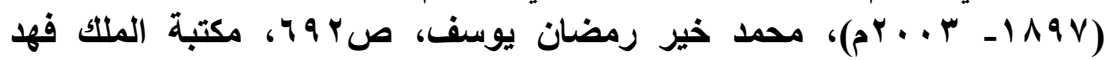

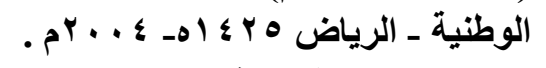

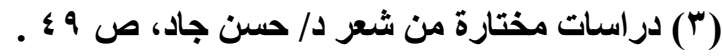


موقنٌ بعدم الهلاك ؛ لأنه يتعلق بالسفينة الناجية التي من يتعلق بها نَجَا، وهي جديرة بهذا المعنى؛ فهي رمز على ذلك، وأصبح علمًا عليها؛ كيف لا، ومَجرا ها ومُرساها باسم الله المُجيب.

هذه الضراعة وهذا الحب يُظلان العبدَ بظِلَلَ الرِّضا ، وتُُلبسه ردايَ اليقين ؛ ولألك عندما فَقَّ الثَاعر" حسن جاد" فِلْذَة كبده الوحيد : حَوْقَل واسنترجَعْ ، راضيًا بقضاء الله وقدره ، يقول في قصيدته ، مقبرة البساتين (البسيط) :

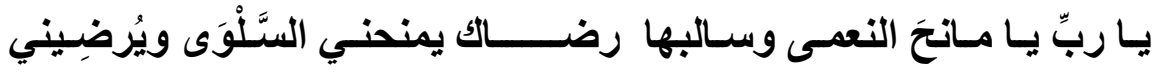

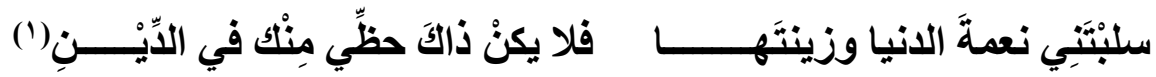
فهو يخثَى أن تفوته الحياة الأبديَّة ونعيمها ، ولا ضير عنده أن يَفْقد من مُتَعِ الانيا ما يَفْقد ؛ فهي زائلة ، لا بقاء لها ، شريطة أن يحفظ الله

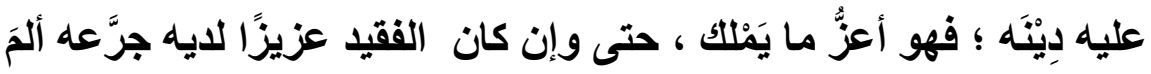

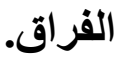

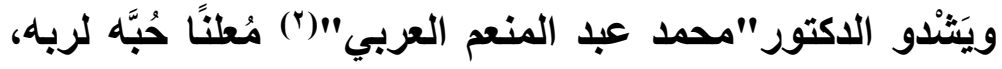
والاعتراف ببرِّه وفضْله وإحسانه ، وكيف لا وهو- سبحانهـ البرٌ الرَّحيم، يعفو ويصفح ، يعطي ويمنح، يقول في قصيدته " الله ": (الرجز)

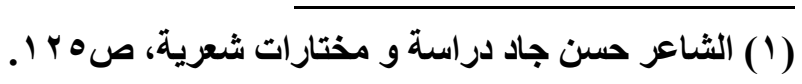

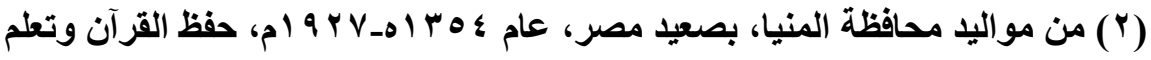
بالأزهر؛ حتى حصل على درجني الماجستير والدكتوراه، فتم قبوله في العمل

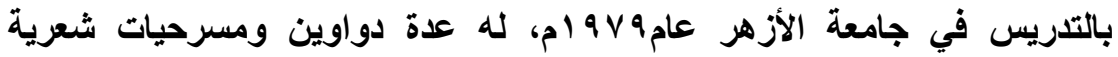

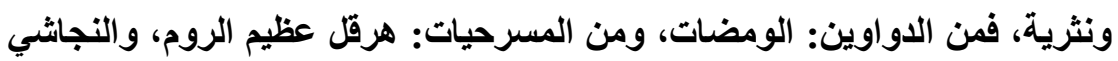




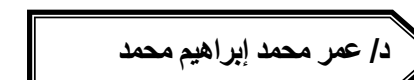

من تجليات الخطاب الصوفي عند شعراء الأزهر في النصف الثاني القرن العشرين

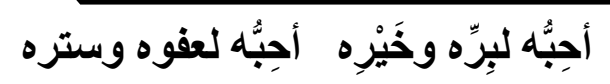

أحِبْهُه لعونه ونصره أحبِّه لخيره الوفير(')

وهذا ليس من عادة الصوفية ـ في غالب الأحيان-إذ هم يُعنون الحب دون سببٍٍ أو مقابل ، أو انتظار عطايا ومِنَح ، فالحُبُّ لذاته -جل فئل شأنهـ ولهذا تقول " رابعة العدوية" في هذا الثأن عندما سألها " الثوري" : ما حقيقة إيماتك؟ قالت: " ما عبدته خوفًا من ناره ، ولا حُبِّا لجنته ؛ بل عبدتُه حُبّا له وشوقًا إليه ، وقالت في معنى المحبة نظمًا على

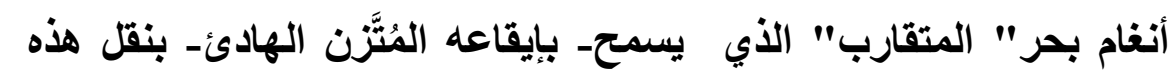
الانفعالات الشعورية والتدفق العاطفي ، تقول:

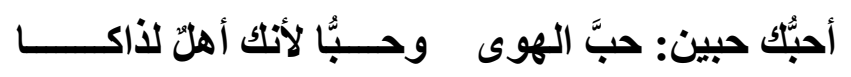
فأمسا الأي هو حب الهوى فشغلي بذِكْرَك عمَّن سواكا

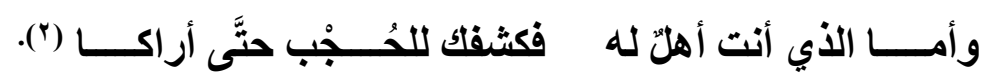

ملك الحبثة. يُنظر : الكواكب الدرية، صاله 1 وما بعدها، شعراء كلية اللغة العربية

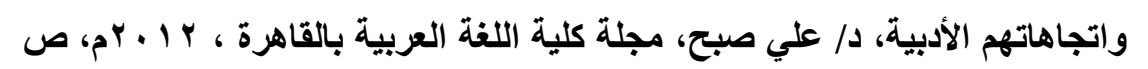

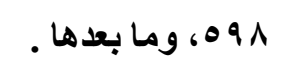

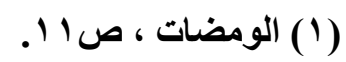

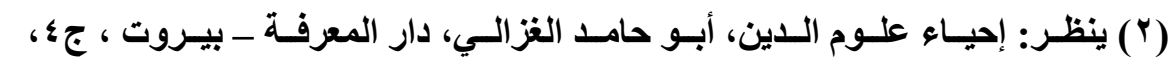

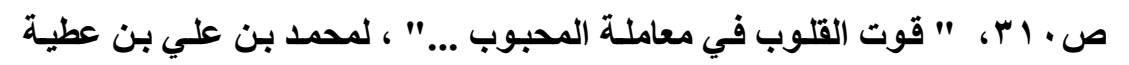

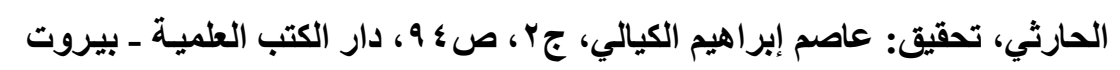

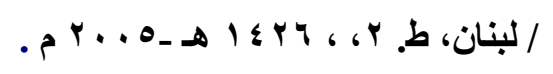




\section{غير أن شاعرنا الدكتور " العربي" أعلن عن حبه وتجربته ،}

معترفًا بفضل الله عليه ، متحدثًا بنعمته ، وهو أمرٌ محبوب مرغوب ، يُثابــ

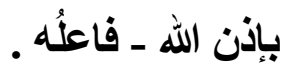

أما الاكتور "عبد الغفار هلال" (1) فيتجلَّى في مَقَّم المحبة في قصيدته: التي عنوانها: " به وُجُودي " التي يعترف فيها بفضل الله عليه، بلاية من نعمة الإيجاد، ثم الإمْداد، ثم الهُى والرشـاد، فيقول: (البسيط)

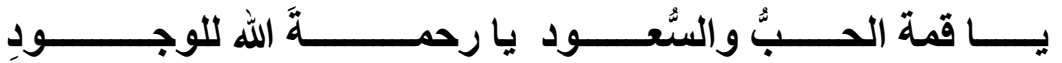

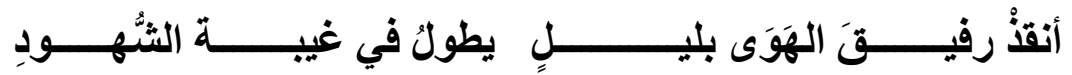

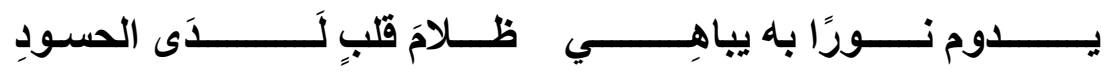

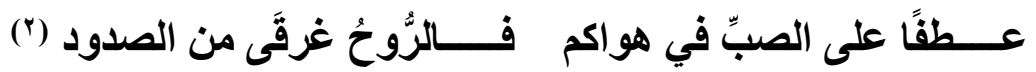
يناجي الثَاعرُ ربَّه، في تضرُّع ولجوعٍ وتدلُّل ،عبر فعل الأمر "أنقذ" الدال على الدعاء والرجاء، كي ينقذه مما هو فيه من لوعةِ الهجر والبُعد والصُّدود؛ فيطول السهر ويكثر السيُّهاد ، فهو واققُ على باب الكريم، ينتظر الإذن بالولوج، يَثْفْع له حُبِّ صادق، ينتظر شعاع نورٍ

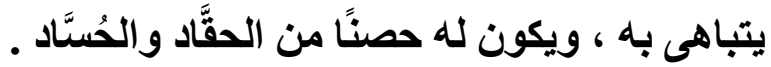

(1) من مواليد محافظة الغربيـة عام هب 9 ام، حفظ القرآن وتلقى تعليمهـ في الأزهر

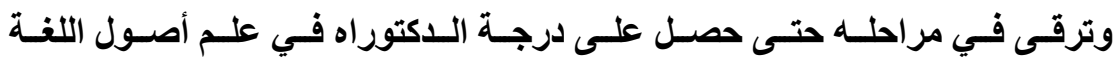

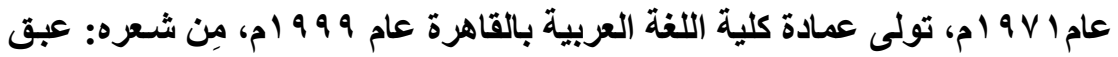

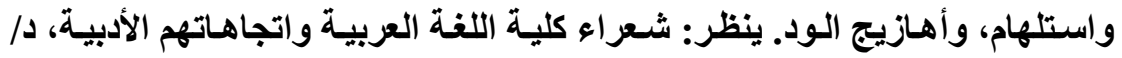

$$
\begin{aligned}
& \text { علي صبح ص و } \\
& \text { (Y) ديوان: عبقُ واستلهام ، ص r Y . . }
\end{aligned}
$$


ويبتهل الدكتور " أحمد عمر هاشم" (')، في قصيدته " مناجاة "،

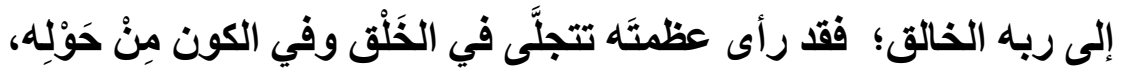

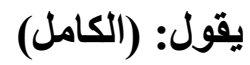

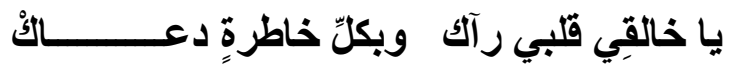

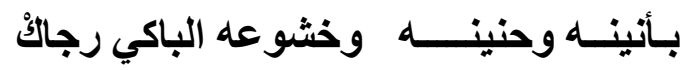

هو لا يبالي بالحيا مِ فِ فحبه منها هُ(أك

هو لا يبالي بالمما تِ فحسبه فيه لقائُ (ن)

يَهِيم الثناعر في مقام القُرب ، يرجو الرضا والقبول؛ فقلبُه لا يرى سوى خالقه، لا يلْوِي على شيء؛ حسنبه -في الدنيا- أنه في نور الهُى لئه

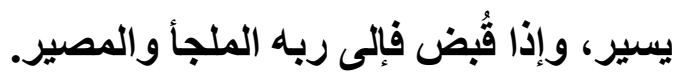

إلى غيرها من النماذج الدالة على الحُبِّ والقُرْب، و الخوف والرجاء،

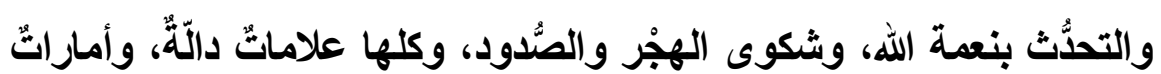

(1) من مواليد الثرقية عام 1 9 (1م، حصل على رسالة الدكتوراه في الحديث وعلومه

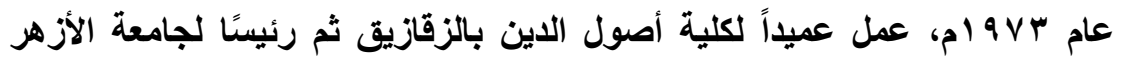

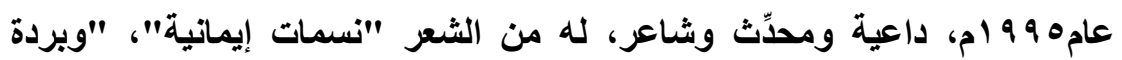

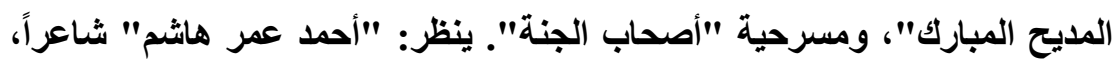

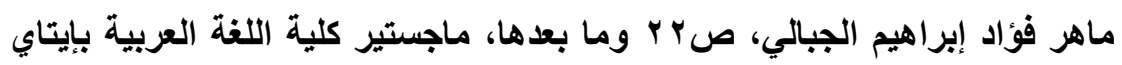

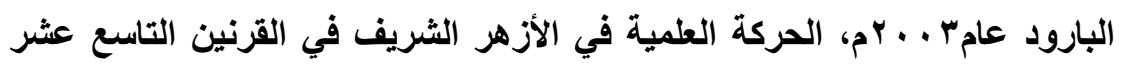

$$
\begin{aligned}
& \text { والعشرين، ص بrآT. }
\end{aligned}
$$

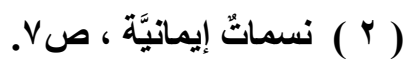


شاهدةُ على تجربة شعرية حقيقةـ في معظمها- عند شعراء الأزهر، تقطر شوقًا إلى الأَّات الإلهيَّة ، كيف ولا وهو البرٌّ الرحيم ، اللمُنعم الكريم.

المطلب الثاني: المدائح النبوية والأماكن المقدسة

$$
\text { أولاً : المدائح النبوية }
$$

تقع المدائح التبوية، التي تتغنى بحب التبي وتوقيرهـ فيما لا يتجاوز بشريته فـي المرتبة الثانية، في شعر التصوف، بعد المحبة الإلهية، بلأت في صدر الإسلام الأول على لسان "حسان بن ثابث"، و" كعب بن مالكا" ، وغيرهما ، ثم كاتت " بُردة "كعب بن زهير"التي أنبنى عليها معظم قصائد المديح عبر عصورٍ ودهور، حتى استوي هذا الاتجاه على سوقه في القرن السابع الهجري على يد إمام المادحين" شرف الدين البوصيري""(')، الأي نظم بردته، والتي عارضها كثير من الشعراء منهم"أحمد شوقي" أمير الشعراء في" نهج البردة "، وكثير من الثعراء في الماضي والحاضر ؛ لما لها من أثرٍ في قلوب الشعراء ، و والمتلقين جميعهم .

وقد عبَّر شُعراءُ الأزهر عن هذا الحب في نَظْمٍ شُرِّف بذِكْر الحبيب ، والثناء عليه ، واتِّباع هذيه والنور الذي أُنزل معه ؛ فالشعر- وهو النابع

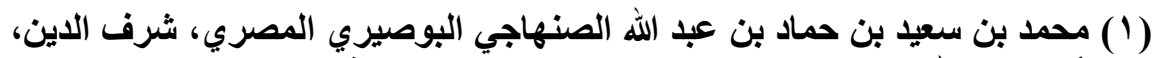

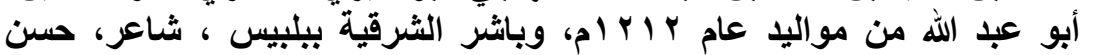

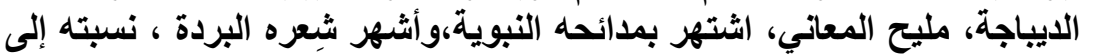

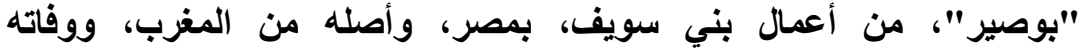

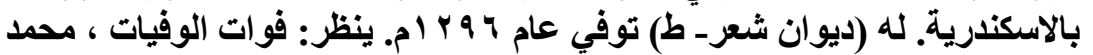

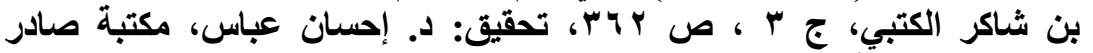

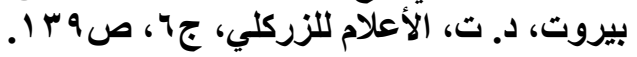


من أعماق الثعور- لا يستنكف من التحليق في سماوات الحُبِّ الثاسعة ، يقول الشيخ " محمود هاشم " ('): (الكامل)

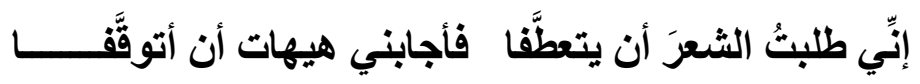

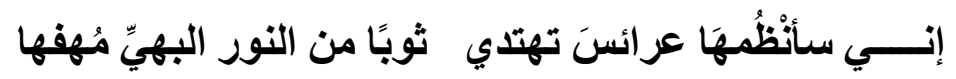

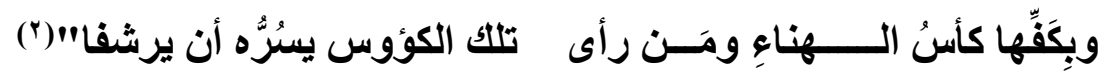

وهي قصيدة بلغتنْ شـهرتها الآفـق، تغنَّى بهـا المبتهلون والمدَّاحون؛

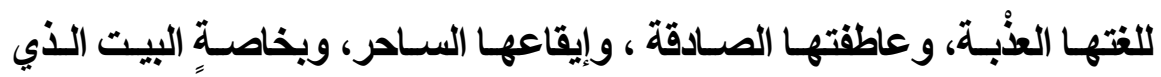

يقول:

عذرًا رسولَ الله إن قصَّرْتُ في وصفٍ فِان جمالَكم لن يُوصفا

إلى آخر القصيدة ، التي تتحدث عن إكرام الله لتبيهه ، وصعوده السبع

الطباق ، وولوجه سدرة المنتهى ، ثم أوَبته ؛ وقد فاض الله عليه من نوره .

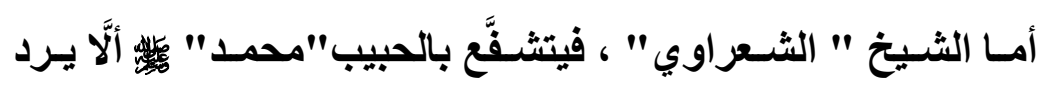

زوَّراه بخُفَّي حُنـين ،أو يرضـوا مـن الغنيمـة بالإيـاب، فيقـول: (البسـيط)

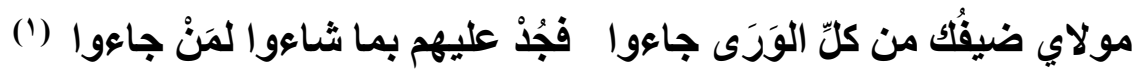

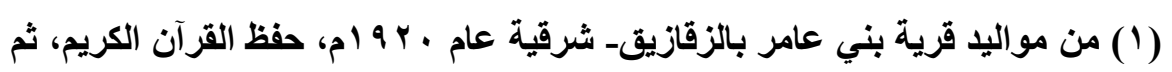

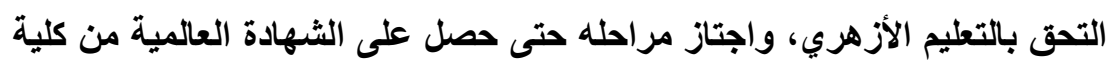

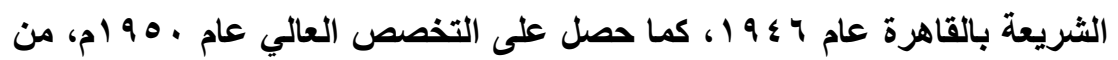

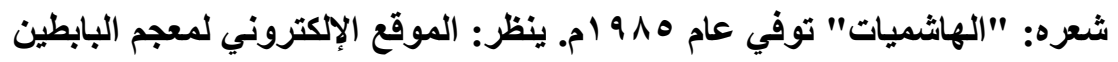

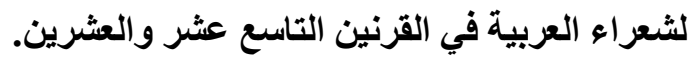

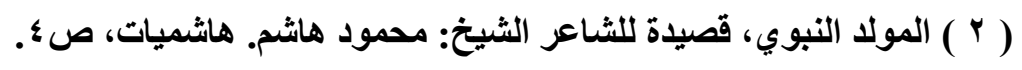


يطلب منه الجود والعطاء\} بأمر الله\{ ، لمن قصد قبره الشريف ومدينته المنورة ؛ بَيْد أنـه أجْوَد من الريح المُرستلة، يَرْجون حُبَّه، وطاعته، وشفاعته، والقصيدة دالةٌ من عتبة عنوانها - وهي" في ضيافة رسول الله"- أن الشيخ ارتجلها/ نظمها وهو بين هذه الحشود الهادرة ، فكاتت نابعة من عاطفة صادقة ، يلقُّها شوق المحبين. وَوَعَى شعراء الأزهر- استنادًا إلى آياتٍ وأحاديثَ صحيحةــ أن الصَّلاة عليه ، وترطيب الألسنة بذِكْره، تنقضِي بها الحاجات وتنفرج بها الكُربات، ومن ذلك ما قاله الدكتور "أحمد عمر هاشم" : (الكامل)

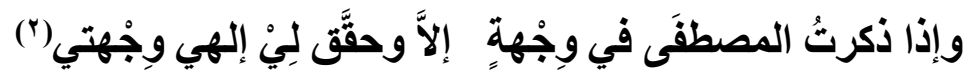

وهنا يعبر الشاعر-في مدحه- عن الفهم المنضبط للعقيدة الصحيحة، دون غلوٍ أو تقصير، بأن الله-سبحانهـ هو الأي يُحقق-بسبب مابِ

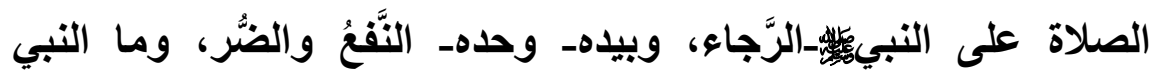
المصطفى إلا بَثَرَر اصطفاه ربّهُ، وجعله خاتم الرسل والتبيين ، نتوسل لله به ، لمكانته عنده ، ونطلب له الوسيلة والفضيلة والمقام المحمود ، ونرجو منه الثفاعة، وقد عَدَلَ الشاعزُ عن الاسم الشريف "محمد" إلى الوصف" المصطفى" ؛ ليثير إلى هذا الاصطفاء، وتثلك المنزلة .

$$
\begin{aligned}
& \text { (1) ديوان الثيخ الثعراوي ، ص } 9 \text { ابـ }
\end{aligned}
$$

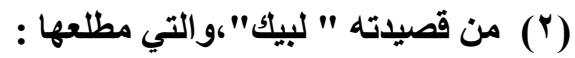

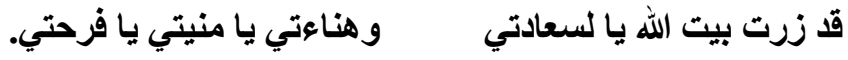

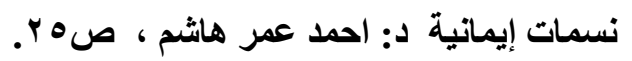


ونرى الاكتور"صابر عبد الايم"(') وهويطير في جنبات الشوق

المُحمديّ، في قصيدته "أين الطريق إليك؟" في مدح النبي محمدئس يقول:

(الكامل) (ال)

أين الطريق إليك في زمن تنا فس كل ما فيه لمحــــــو خطاكا ؟؟

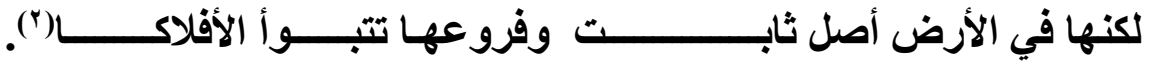

فيعترف الثاعر بأن الطريق إلى شرعة التبي محمد بs وسنته، قـ

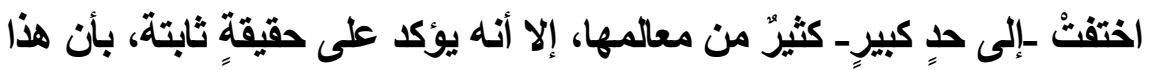
المنهج، هو منهجُ ثابت البنيان،متين الأركان، مُتَرستَخ في القَب والجَنان، وفروعه وأغصانه باسقاتٍ تتجاوز العنقاع، يدعو الشاعر للتمسك به ، والعضّ عليه بالنّواجذ؛ فقيه السعادة والفوز في الآخرة والأولى .

وقد عمد بعض شعراء الأزهر إلى النَّْْ على منوال البردة الأصيلة بردة كعب بن زهير ، ومنهم الثاعر الدكتور "عبد الغقار هلال" في ديوانه المستقل الأي جعل عنوانه " نهج البردة" ، وقد استهلها بقوله : (البسيط)

(1) من مواليد الثرقية عام ^ ؟ ا م، حصل على درجة الدكتوراه في الأدب والنقد

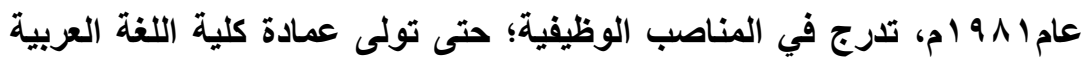

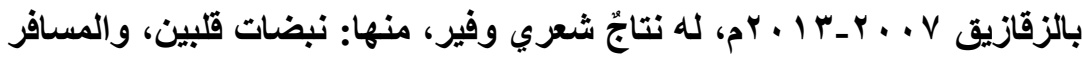
في سنبلات الزمن، والمرايا وزهرة النار، والعاشق والنهر، إلى غيرها من الأعمال الشعرية والمؤلفات والبحوث النقدية. ينظر:" الكواكب الاريَّة في سِيَر

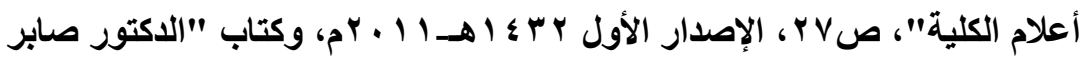

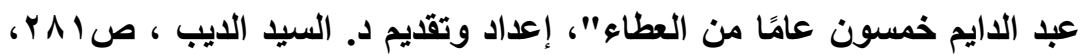

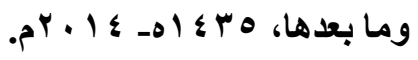

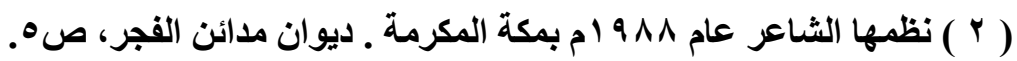


يُشْنجِي الفؤادَ حنينٌ فيهه موصولُ وفوق أيك الهوَى ما عنه تحويلُ

باتتْ تغنِّي على ساقِ مُطوقة تدعو هديلًا نأى والقلبُ مشغولُ

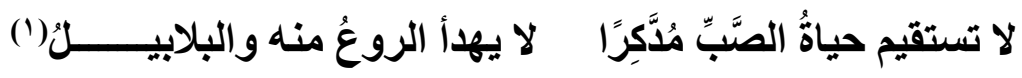

والقصيدة معارضة لقصيدة "بانتُ سُعاد " متوافقة معها في

الغرض والهدف والوزن والقافية ، فضلَّ عن العاطفة التي اشرأبَّتْ مُعلنة

عن نفسها في الاستهلال؛ فالفؤاد يُشجيه الحنينُ الصادق للمحبوب ، لا

يَتبَِّّل هذا الشوق ولا يَتحوَّل ، فكاتت المعارَضة التلك القصيدة التراثية ـ ـ وهي أم الباب في هذا الغرض- وسيلته الناجعة في التعبير عن هذه الأشواق الكامنة بين الجوانح .

كما كان للبردة البوصيرية (广) تسلُّطُ وأثُرُ ظاهرٌ على الشعر الأزهري(")؛ إعجابًا بنظمها وموضوعها وأفكار ها ومعاتيها، ومن هؤلاء: الثاعر" هاشم الرفاعي" (4)، الأي قال في مطلع قصيدة له بعنوان " نهج (البردة في مدح أشرف المرسلين" : البسيطي

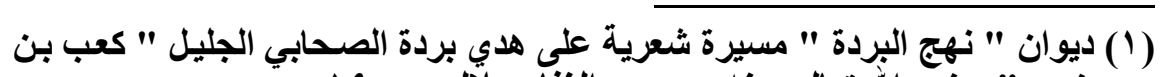

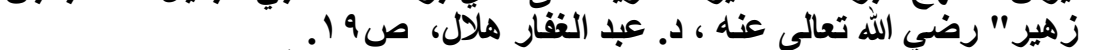

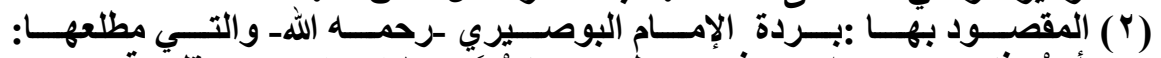

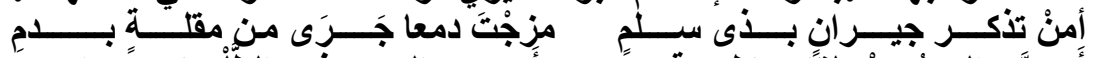

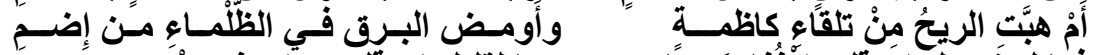

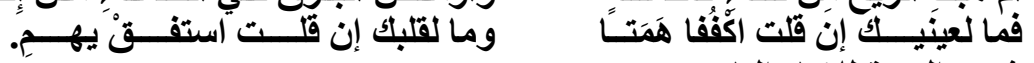

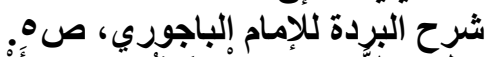

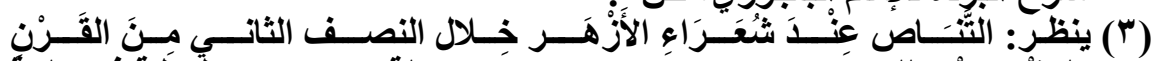

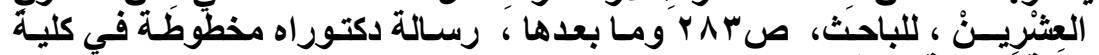

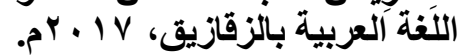

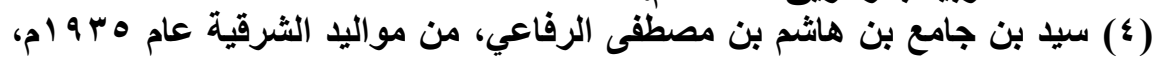

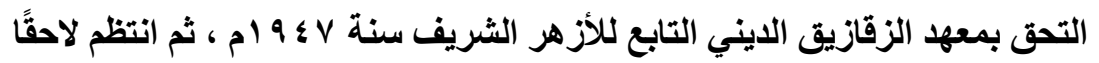




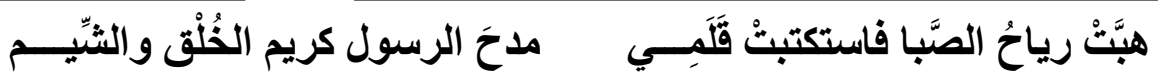

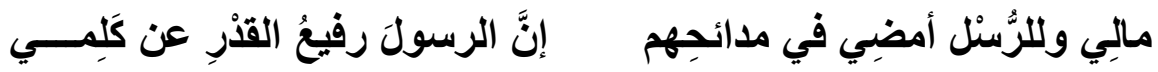

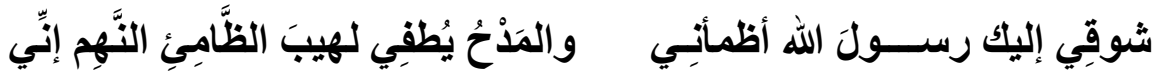

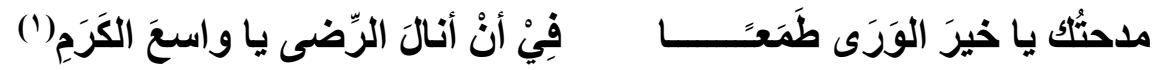
فالعاطفة والاستهلال والألفاظ والمعاني، مستوحاة من القصيدة الرئيسة ، وتشير على هديً منها ، وإذا كان "الرفاعي" يخشى- كما يقولمن الخوض في مدائح الأنبياء؛ مبالغة في التززيه والتشريف ، فإن "البوصيري" قد سبقه بذلك، في قوله : (البسيط) لو كنتُ أعلمُ أنبّي ما أوقِّره كتمتُّ سرِّا بَََا لِي منه بالكتم و"الرفاعي" يطمع في الشفاعة والرضا والقبول، وهو ما يرنو له "البوصيري" في نهاية القصيدة ـكذلكـ فيقول: (البسيط)

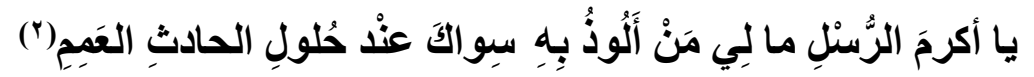
فجاءت القصيدة متفقة مع أفكارها ومعانيها، فضلاً عن الموسيقى والجزْس والإيقاع الذي يُّكِّر بالبردة ، ويعمل على محاكاتها ومحاورتها واستنطاقها والتناص الكُلِيِ معها.

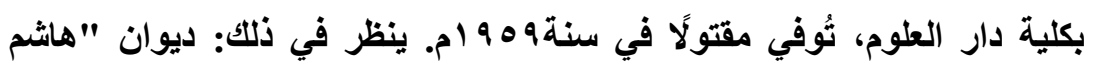

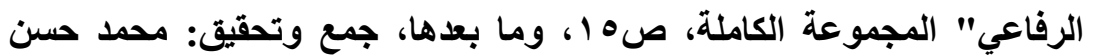

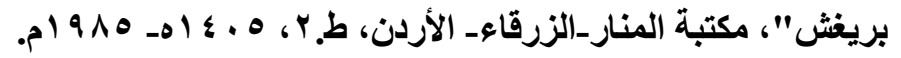

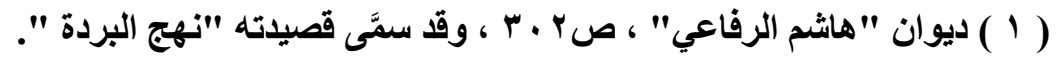

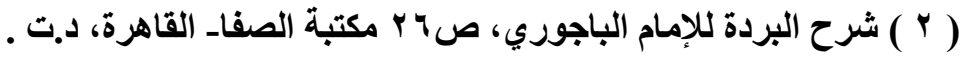


ومن ذلك_أيضًا_قصيدة "نهج البردة" للشاعر الاكتور "أحمد عمر

هاشم" التي عارَض بها بردة الإمام "البوصيري"- رحمه الله- فآثز موافقة إمام المادحين، سائرًا على نهجه، في غير تحدًّ، فيقول مُعلنًا تواضعه، وقد جعل معارضته حُبًا لمن يعارضهم: (البسيط) نهجتُ نَهجَ إمامَ المادحين فلا

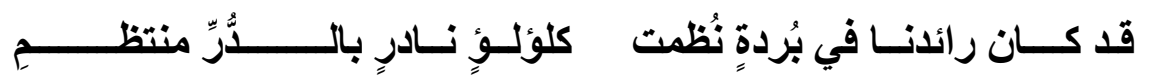

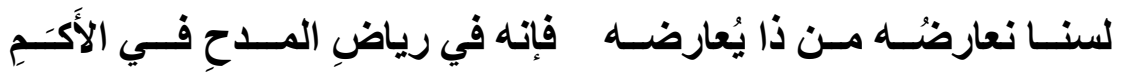
وهو متوافقّ- بشكل كبيرَّ- مع ما أقرَّ به " أحمد شوقي" في مقدمة معارضته للبوصيري، في قصيدته " نهج البردة " ، إذ يقول('):(البسيط)

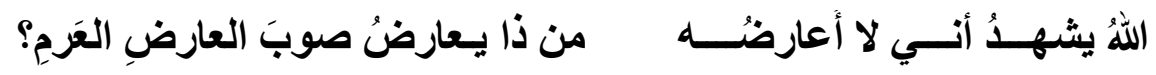

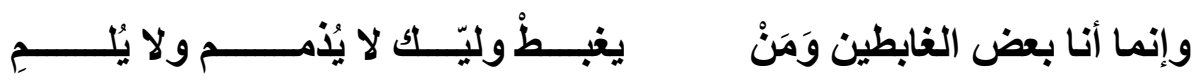
وقد ظهرتْ قدرة الشاعر الدكتور "أحمد عمر هاشم" على التعبير عن شوقه إلى الممدوح / النبي محمد

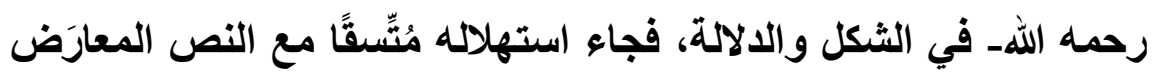
في تناصِ اجتراريٍٍ مُحوَّر، فيقول:

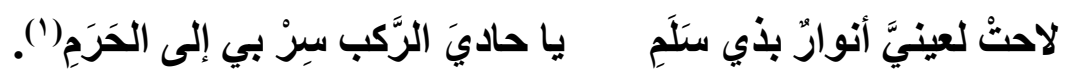


انتظمتُ القصيدة على بحر البسيط التام، الذي يمتاز ـكما هو

معلوم- بطول النَفَس وحلاوة الجرْس، وقَ وقَعَ النصٌُ المعارِض كله من أول القصيدة إلى منتهاها في نفس سياق النص المعارَض،على المستوى الإيقاعي والغرض الشعري والعاطفة المسيطرة على كِلا الشاعرين، فقد وقعا في أسنر الحبِّ المحمديّ، وعاشا نفس التجربة؛ فجمعتهما معًا على مائدة المديح والحب الفصيح.

كما أن الثاعر "هاشم" سار على درب"البوصيري" في استدعاء الأماكن ذات الثَّرى الطاهر وصِلَتها بالرسول الأكرم، وهي عادةُّ

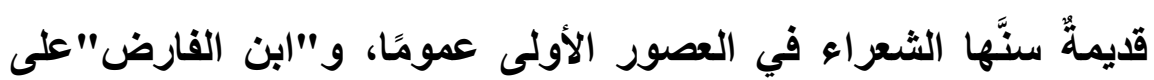
وجه الخصوص، في قصياته التي عنوانها: " هل نار ليلى بلت ليلاً " ، وقد استهلها بقوله: (البسيط)

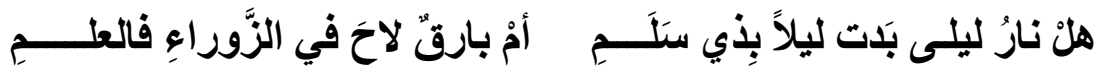

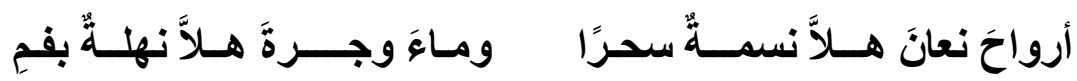

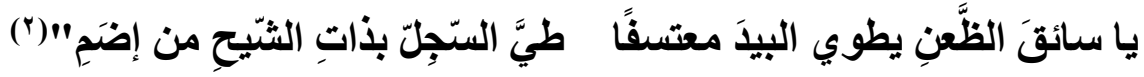

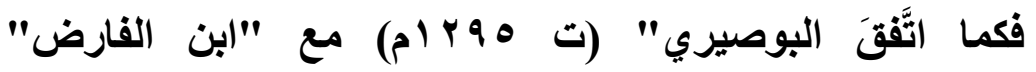
( ت ع r ام) توافقًا ظاهرًا في الاستهلال وبعض أبيات القصيدة، إلا أن شعراء الأزهر تناصّوا تناصَّا كليَّا مباشرًا مع بردة البوصيري في الشكل

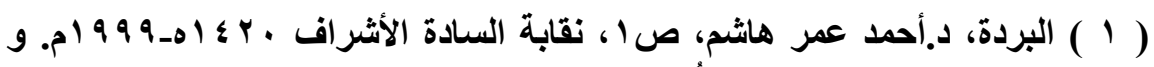

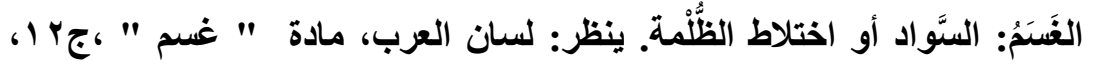

$$
\begin{aligned}
& \text { صVVIR. }
\end{aligned}
$$

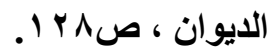


والمضمون وما إليهما في تعالقٍ حتميٍٍ بين البنية الإيقاعية والبنية

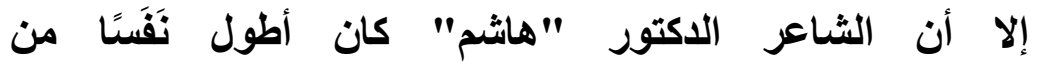

"البوصيري"؛ فقد بلغت "البردة" الأصيلة مائة وستين بيتًا، في حين أن بردة "هاشم" كاتت مائةًَ وواحدًا وسبعين بيتًا، مع اتفاقهما في التعبير عن

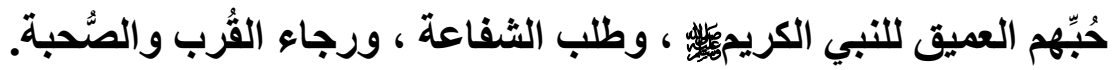
ثانيًا: الحنين إلى الأماكن المقدسة :

عندما أذَّن الخليلُ "إبراهيمُ" ـ عليه السلامـ في الناس بالحجِّ : ضَمِن اللهُ له استجابة ندائه ، فبات الثوق إلى هذه الأماكن المقدة راسخًا في وجدان المُوحِّدِن، يُقبلون عليه محْمولِيْنَ ورجالَا، ويسعون إليه زرافات ووحدانًا؛ " فالقلوب المؤمنة تظل معلقة بظلال وأطياف الأمكنة التي تحمل عبق الوحي، ويظل القلب متعلقًا بها تعلقًا رُوحيّا وعقديًا" (')، وكان لشعراء الأزهر تجاربهم مع تلك المشاعر والشعائر، فسطرَّوها بمدادٍ من وَجْد القلوب ، ومَاعِ المُقَّل ، ومن ذللك ما نجده عند الدكتور "حسن جاد"، في قصيدته:"في ظلال الحرم" ، يناجي فيها البيتَّ العتيق ، قائلًا: (المديد) يا حِمَى الكعبة والبيت الحــرام للكِ يـا أمَّ القُرى مِنَّا السَّلام

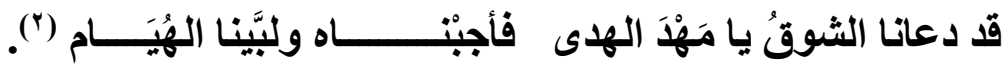

( 1 ) ينظر: الأدب الصوفي الإسلامي( اتجاهاته وخصائصه)، د: صابر عبد الدايم،

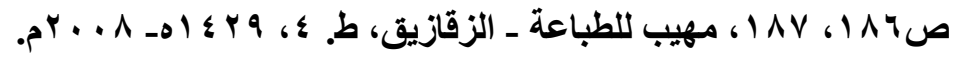

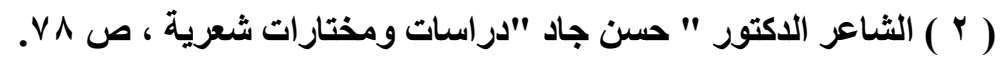


يعترف الثَاعر بأثشواقه للكعبة المشرفة، وهُيَامِه بتلك البقاع الطاهرة، هذا الثوق الأي أرغمه على القصد والزيارة، وتَكَبُّ مشقَّات السَّفر والتَّرُّل، وقد ذكر الكعبة والبيت في شطره الأول، ثُ أجمل في الشطر الثاني "مكة المكرمة"، من باب ذكر العام بعد الخاص؛|هتمامًا بثأن ذلك الخاص، وهي الكعبة المشرفة .

والنظر إلى الكعبة من أسباب حب البَقَاء في الانيا عند الدكتور " أحمد عمر هاشم" ، فيقول في قصيدته " لبيك" : (الكامل)

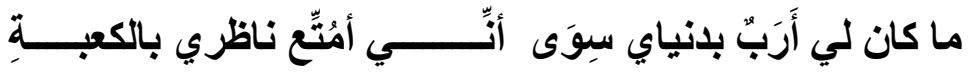
وأسيرُ ما بين الحَطِيِ وزمزمٍ وأجولُ ما بين الصَّفا والمَزْوةٍ

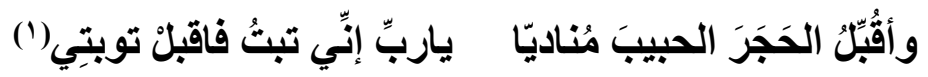
يصف الثـاعر بعض الأماكن التي تؤدى فيها المشاعر والنُّكك ، يصفها ويذٔكرها؛ تعظيمًا لها والاعتراف بمكاتتها وفضلها ، فلها شرف المكان وشرف التعبُّ، مؤثرًا الفعل المضارع الذي يلقي بظلاله على الحدث، وغاية

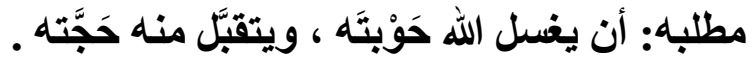
المطلب الثالث: الدعوة إلى الفضائل ومكارم الأخلاق

اعتتتُ الصوفية الحقَّة بمكارم الأخلاق والالتزام بآداب الإسلام ؛ حِنْبةً لله، وطلبًا للأجر والمثوبة،، لا رياءًً ولا نفاقًا ولا تكلًُّا، فلا يستقيم (1 ) نسمات إيمانية د: أحمد عمر هاثم ، صع r. 
الأمر، والقول غير الفعل، والباطن خلاف الظاهر؛ فالباطن مقدم على الظاهر، والفعل مُقدَّمُ على الكلام، قَالَ الجنيد : " إِذَا رأيت الصوفي يُعنى بظاهره (فقط] ؛ فاعلم أَن باطنه خراب")(')، ولذلك عمد شعراء الصوفية ومعهم شعراء الأزهر الذين أثَّرتْ فيهم النزعة الصوفية ، إلى الدعوة إلى هذه الأخلاق التي ترتقي بالنفس وتهذبها ، وتصعد بها إلى النفس المطمئنة ، وكان على رأس هذه الدعوات الدعوة إلى العفو والصفح ، وعدم الاتتصار للنفس وانتظار الأجر من الله ، ومن ذلك قول الشيخ " محمود هاشم " ،في قصيدته " العفو عند المقدرة ": (البسيط)

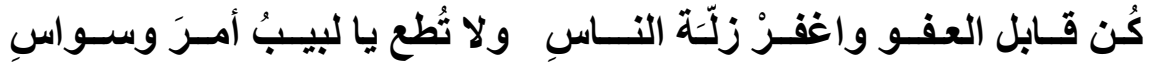

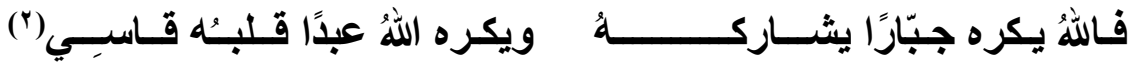
ينصح الثاعر بسماحة النفس، وقبول العُذْر والعفو عن المسيء ؛ والتواضع وخفض الجناح ، يقول الجنيد" ،عندما سُئل عن التواضع

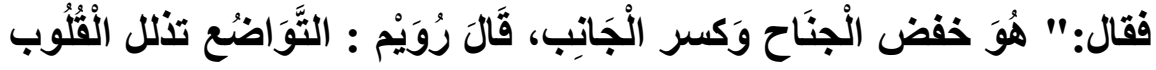
لعلام الغيوب"، فالقلب القاسي بعيدٌ عن ربه، بعيد عن عفو الله ، ثم يذكره بأجر العفو والصبر على الأذى يوم القيامة ، فيقول:

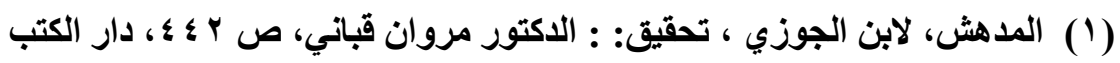

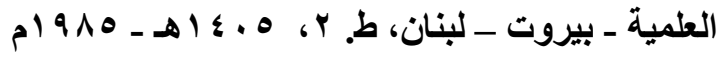

(Y) من قصيدة: " العفو عند المقدرة" للثاعر الشيخ: محمود هاشم. هاثميات، 


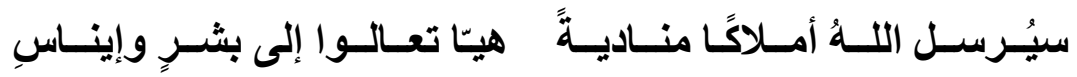

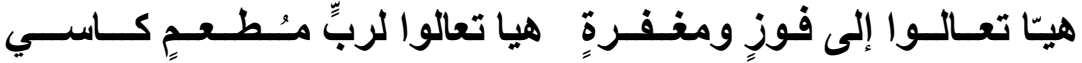

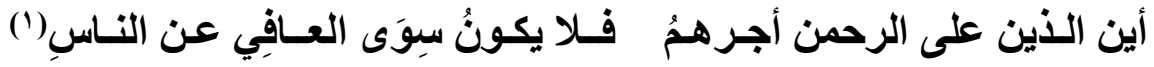
والمتأمل في هذه القصيدة ، يجد أنها مُطعمة بالبِشر والأمل في رحمة الله ، والتحريض على العفو عن الناس والتيسير عليهم ، وفيه إثـارة قرَ آنية إلىى قوله تعالى في فضل الصبر والصفح : " فمَنْ عَفَا وَأَصْنَحَ فَأَجْرُهُ

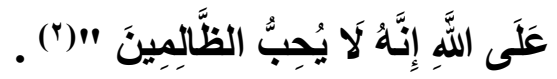

وينادي الدكتور "سعد ظلام" (")، في قصيدته "الحِقٌُُ لا يبنِي" (؛)على الأي يُتعب نفسَه في الحقد على بني البشر ، فيقول: (الكامل) يا أيها المقتول بالسهم الأي صوبتَه للحُبِّ والأمل الكبير الحُبُّ يبني فكرة الإنسان يبني يومَه وخُطاه نحو غدِ وثير يريد أن ينصحه بإحلال الحب مكان الحقد ، فهو أول المُضسارين من هذه الأمراض القلبية ، أما الحب فيني لا يهام ، فالقلوب التي تحوي الحب والخير كبسمة خضراء يانعة : لا تعرف معنى الأبول ، يقول:

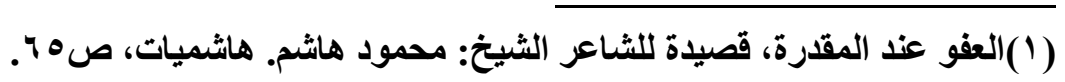

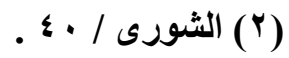

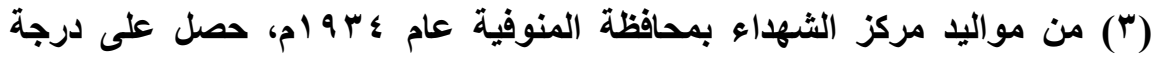

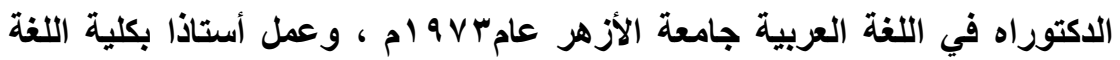

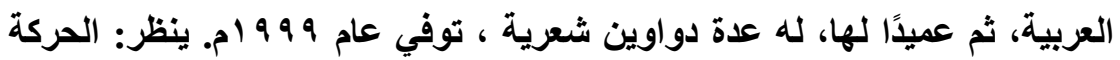

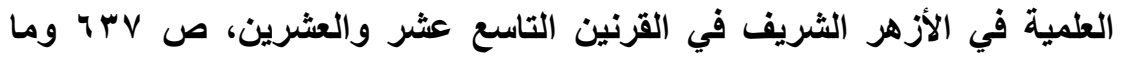


وقلويُنا كالبسمة الخضراء كاللر روح النبيل وكالأغاني والسروز

لا الحقد يعرفُها ولا تهفُو إلبا ـه غوى وليست في دوائره تلدوز

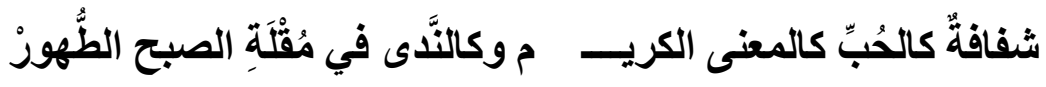

يصور لله المعقول في صورة المحسوس؛ ليقرب له الصورة،

فيحمله على الإقتاع، وهو ديان أصحاب النزعة الصوفية في حرصهم على نقاء السرائر ، وطهارة القلوب؛ إذ هي محطُ نظر الله ، المعبود المحبوب دئ

الأي ينبغي ألا يَنظر إلا إلى ما يحبه .

ومن المضامين المبثُثتة في شِعْرهم، والتي تعمل على تهذيب

السلوك والإقبال على الآخرة: الدعوة إلى الزهد في الدنيا والحذر منها ، وهناك الكثير من النماذج التي تدلل على ذلك، منها ما جاء في قول الشاعر "محمد الأسمر" (') ، يقول: (الرمل)

$$
\begin{aligned}
& \text { ليت شعري أي شيع في حياة لممــات ووجــودِ لـــزوالِ }
\end{aligned}
$$

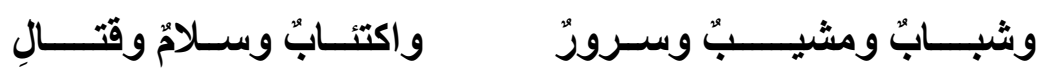

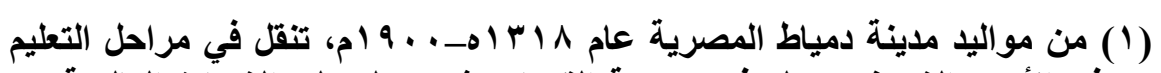

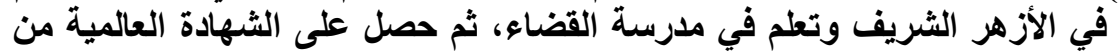

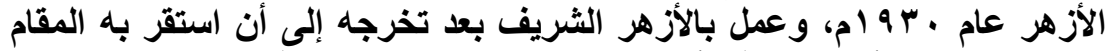

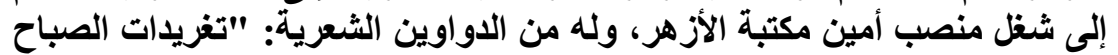
"

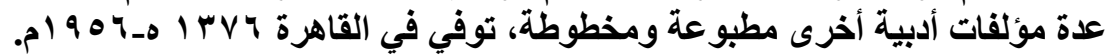

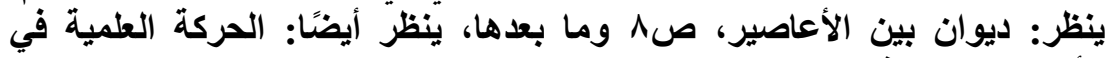

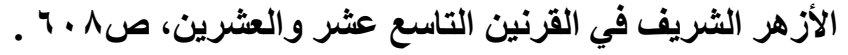




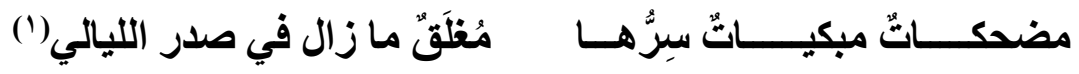

فالدنيا ليست دار قرار أو أمان، بل هي بالناس قُلَّب ،منظلقةٌ على ذاتها، لا يعرف أحدٌ ما تخبئه من أسرار وأخبار، وليست لها من الابتسامة إلا ما تظهره من أطراف أسنان، عمد الشاعر إلى هذا الأسلوب التحذيري في وصف الانيا؛ ليحمل المتلقي على معرفة حقيقتها، وإدراك غايتها ، فيذهب إلى ما يُعمّر الدار الأخرى الباقية، وهو ما صرَّح به الشاعر الاكتور" محمد عبد المنعم العربي" في صَّيحة أطلقها ؛ ليحذر من هذه الدار والاطمئنان إليها ، فيقول : (الكامل)

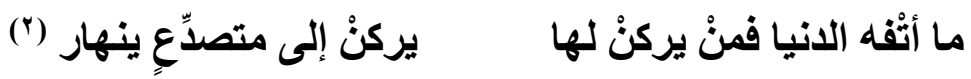

وأثر البيان القرآني ظاهر في البيت ، فهو يتعالق مع صورة بيانية قر آنية (") ، وقد آثر أسلوب الشرط الذي يفيد التحذير من ذلك المصير الذي

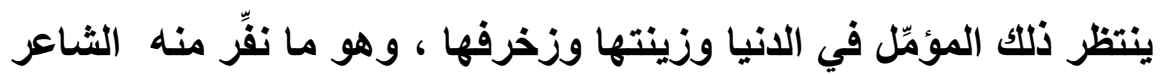
وحذَّر من مَغبَّة السير في سبيله .

أما الشاعر"عبد الله شمس الدين" فيعمد إلى امتصاصٍِ تجربة "زهير بن أبي سُلمى" الشعريةة، في تصوير يَأسِه من الحياة وما فيها من متاعبَ وشقاعِ ونَكَ، فيعيد صياغة هيكلتها اللفظيَّة، يقول: (الكامل)

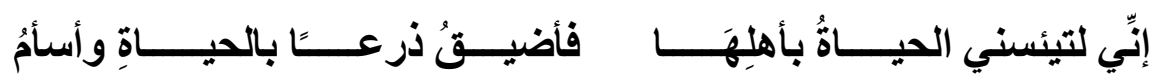

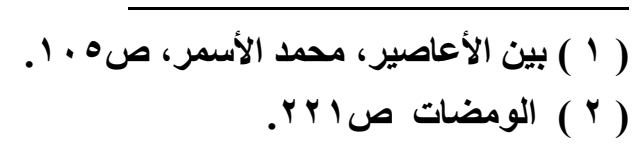

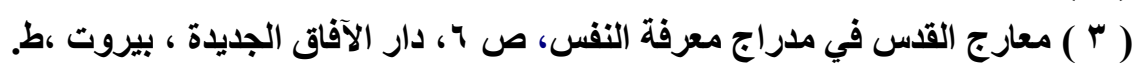

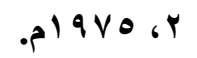




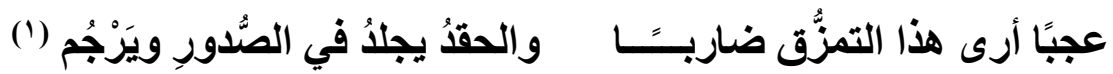

يُحيل الشاعر زهدَه في الانيا إلى ما يراه من ضغائنَ وَإِحَن ، تضيق بها صدور الخلق، فيضيق فؤادُه لهذه المشاهد ؛ فيسأم من حياته ، ويزهد في البقاء في الدنيا ، لأنها يحب الأجواء العُلْوية التي لا غلَّ فيها ولا حسد، كما ييأس من هؤلاء الفئة التي تتصف بهذه الصفات القميئة . والزهد الحقيقي الأي ينبفي الدعوة إليه لا يكون بالتكلُّف في المُرقَّع من الثياب ، أو التبذُّّ في الإهاب، بل التعبُّ الصحيح هو إظهار التعمة، بل بل والتحدث بها في غير غرورٍ أو تكبُر، فالله ـتعالى- جميلّ يحب الجمال، ولالك يوضح الفكر التظيري الصوفي الحق، فيقول صاحب " المُدهش"

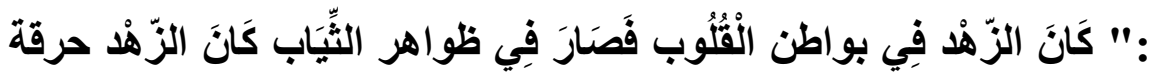

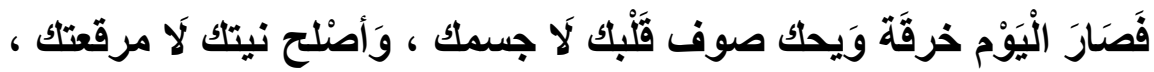

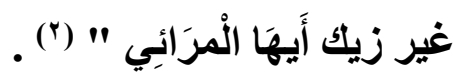

وهكذا يكون التصوف ـالحقيقي- مُعينًا في طريق السير إلى الله ، وهو ما عَقِّه السلف والخلف من العلماء والدعاة والمُصلِحين، فهو منتهى آمالهم، وغاية مطلبهم؛ فقد كان جهدهم -بالإضافة إلى الجهود العلمية والاعوية والإصلاحية_مُنصبَّا على ترقية النفس وأخذها بالمجاهدة والمحاسبة، من كونها أمّارة إلى كونها لوّامة، حتى تصل إلى المطمئنّة، ولن يتمّ هذا إلاّ بفظم النفس عن المألوفات ، وحملها على خلاف هواها،

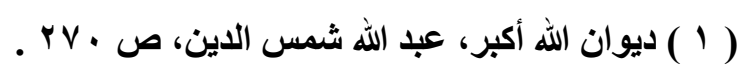

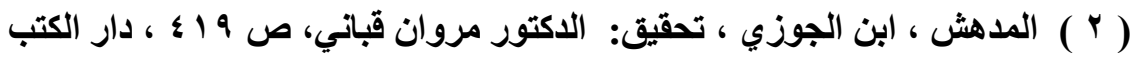

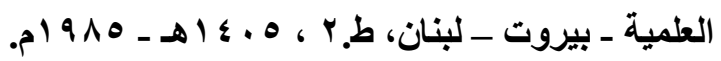


وقد حاول بعض شعراء الأزهر المشاركة في هذا المضمار تنظيرًا وتطبيقًا وإبداعا.

المطلب الرابع: التعرّف على حقيقة النفس الإنسانية

كان التعرف على حقيقة التفس الإنسانية مجالًا خِصْبًا للاختلاف وتنوع الآراء بين الفلاسفة والمتكلمين ، منذ قرون، باية من اسمها حتى مضمونها، فهل هي والروح والعقل والقلب بمعنى واحد، أم بينهما اختلاف، وهل هي خالدة أم حادثة ؟ وهل تعني الإنسان بجملته، أم تعني هذا السر المُودَع في الجسم، إلى غيرها من أقوال الفلاسفة من أفلاطون وأبي علي بن سينا في كتابه:" الإشارات و التتبيهات، و" أبي حامد الغزالي" في كتابه: "معارج القد في مدارج معرفة النفس". والأي نريد أن نعرِّج عليه في هذا البحث الموجز: هو التعرف على حقيقة النفس الإنسانية عند شعراء الأزهر من خلال منجزهم الإبداعي الشعري ؛ سيرا في طريق المتقدمين من الفلاسفة والشعراء، وبخاصة من اعتنوا بالفكر الصوفي ، ومنهم حجة الإسلام " أبو حامد الغزالي" الذي شَفَََه معرفة النفس وحقيقتها، وهو ظاهر من خلال عتبة عنوان كتابه " معارج القد...-- ذلتك المضمون الأي يسري بين دفتي سِفْره، كما أن مقدمته تدل - كذلكــ على الهدف الأسمى من التعرف على النفس الإنسانية ، والغاية من ذلك ليست غاية فلسفية سوفسطائيَّة ، بل هو اقتناع بالعقل يتبعه عملّ بالجوارح، ولذلك يستهل مقدمته، بقوله: "ونحن نعرج في هذا الكتاب من مدارج معرفة النفس إلى معرفة الحق جل جلاله...، ومعرفة قواها وجنودها، ومعرفة حدوثها وبقائها وسعادتها 
وشقاوتها بعد المفارقة، على وجه يكشف الغطاء، ويرفع الحجاب، ويدل على الأسرار المخزونة والعلوم المكنونة المضنون بها على غير أهلها، ثم ختمنا فصول معرفة النفس فحينئ نتعطف على معرفة الحق جل جلاله" (1)

وقد وضعها الثيخ الرئيسُ ابنُ سينا في مقامٍ أستحى، ومرتبة

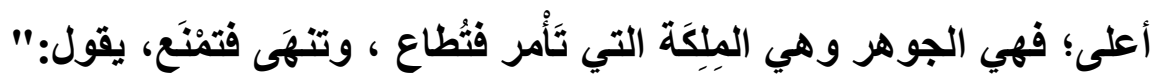
وإنما أعني بالنفس، ذلك الجوهر الكامل الفرد الأي ليس من شأنه إلا التذكر والتحفظ والتفكر والتمييز والروية،...، وهذا الجوهر رئيس الأرواح وأمير القوى، والكل يخدمونه ويمتثلون أمرهن....، فالحكماء يسمون هذا الجوهر النفس الناطقة، والقرآن يسميه النفس المطمئنة ، والمتصوفة تسميه الروح، وتارة تسمية القلب، والخلاف في الأسماء والمعنى واحد لا خلاف فيه، والنفس الناطقة هي الجوهر الحي الفعال المدرك، وحيث ما نقول الروح المطلق، أو القلب، فِإنما نعني به هذا الجوهر " () . هذه النفس كانت لتوازن بين الجسم المادي الشهواني الأي يحن إلى التراب ويهفو إليه فهو مِنْه خُلق، والروح التي تحلق في أجواء عُلْوية سماويَّة، ولألك كان لا بُدَّ من التوازن بين متطلبات هذين النقيضين ، ومجاهدة النفس لتبقى في هذا المكان، هذه المجاهدة وتلك المحاسبة كانت

( 1 ) معارج القدس في مدراج معرفة النفس، ص ף'، دار الآفاق الجديدة ، بيروت ،ط. r

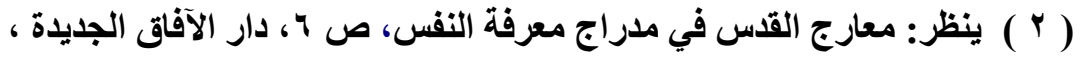

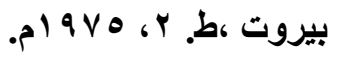


من متطلبات الصوفية الحقَّة ، وفي هذا يقول حُجَّة الإسلام : " أطلق

الشارع اسم النفس، بل أكدها بالإضافة فقال: نفسك التي بين جنبيك " (") .

وقد كان للشعراء الأزهريين ، نظرة نحو النفس وإدراك حقيقتها،

والتأمل في كُنْهرا،ومنازلها وكيف هبطتتْ إلى الجسم من علٍ على كُرْهِ منها وغَضَب، إلا أنها ما لبثت إلا أن تآلفت معه وكرهت فراقه، ومن نماذج ذلك قصيدة الاكتور "محمد عبد المنعم خفاجي" معارضا لقصيدة النفس لابن سينا ، فيقول مطلعها : ( الكامل)

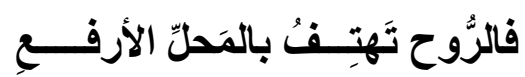

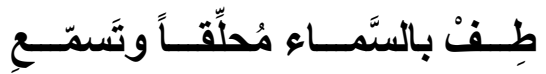

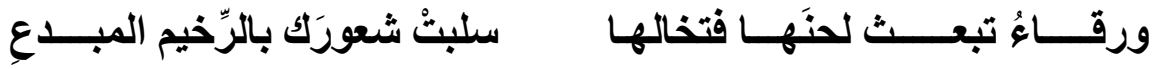

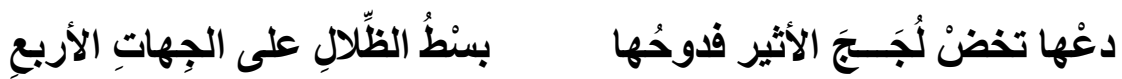

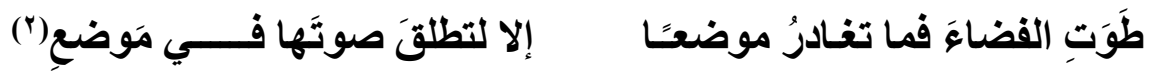
فقا يمَّمَ الثَاعرُ وجهَه نحو منطقةٍ إبداعيةِ ذات نطاقِ تراثيِّ

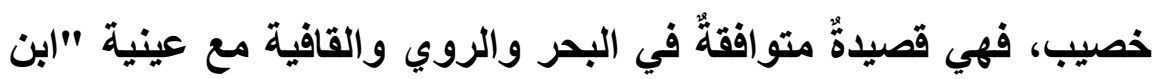
سينا"، وهي قصيدته "النفس"، والتي استهلها بقوله:

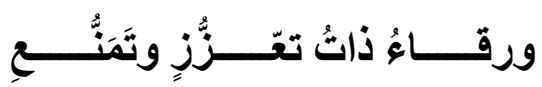

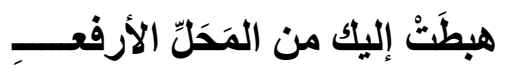

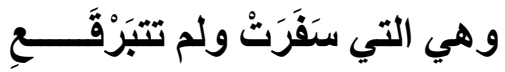

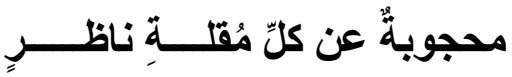

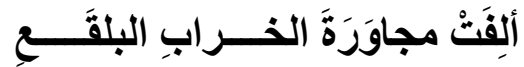

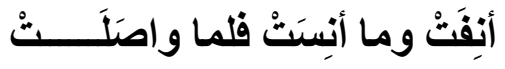

( 1 (الرسالة اللانية، الإمام أبو حامد الغزالي، ص1،، مطبعة كردستان العلمية، AlTY

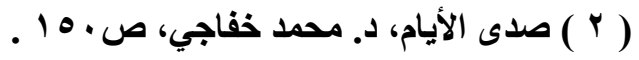




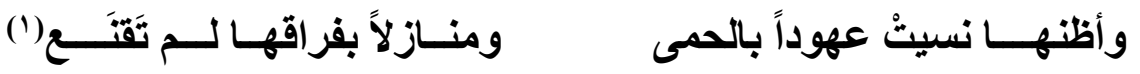

هذه القصيدة المعارَضة كاتت مَحطَّ نظر كثيرٍٍ من الشعراء والفلاسفة؛ لحديثها المفصَّل عن النفس ومكنونها، فقد أودع فيها الشيخ الرئيس خلاصةَ فلسفتهِ التي اقتعع بها بعد طول تفكير وتأمل، ولذلك عارضها أكثر من شاعر في عصورٍ مختلفة . وقد آثر الثاعر الدكتور "خفاجي" عند رغبته في الحديث عن النفس أن يحذو حذو الشاعر الفيلسوف الحكيم "(بن سينا"، وهو ما يؤكد أن تجربة الثـاعر وإحساسه ومرجعيته الثقافية لها دور كبير في بناء و اختيار موسيقى شعره.

فجاءت قصيدة الدكتور "خفاجي" تسير على خُطاها، وتهتدي بِهَذْيها، عبر بحر" الكامل التام" الأي اختاره شَاعره الأي عارَضه، وهو ما يتميز به من كثرة تفعيلاته وأضربه، وعبْر حرف الرّوي "العين" الدال على النصاعة والظهور والبيان، وقد التزمه في قصيدته حتى منتهاها. إلا أن الثاعر الدكتور "خفاجي" أطلق عنان قلمه وخياله، وظل يستطرد في إبداعٍ- بيان هذه الحقائق التي يغقلها الناس؛ حتى جاءت قصيدته على تسعة وثلاثين بيتًا، أما القصيدة الرئيسة فكاتت في واحدٍ وعشرين بيثًا فقط، وهو ما يوحي بتأثير القصيدة على الثاعر على المستوى الإيقاعي والغرض الثعري والعاطفة المسيطرة عليه.

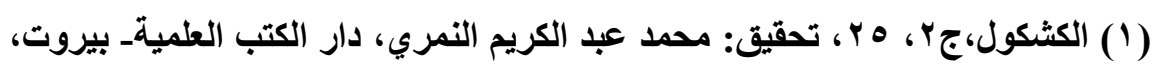
11 


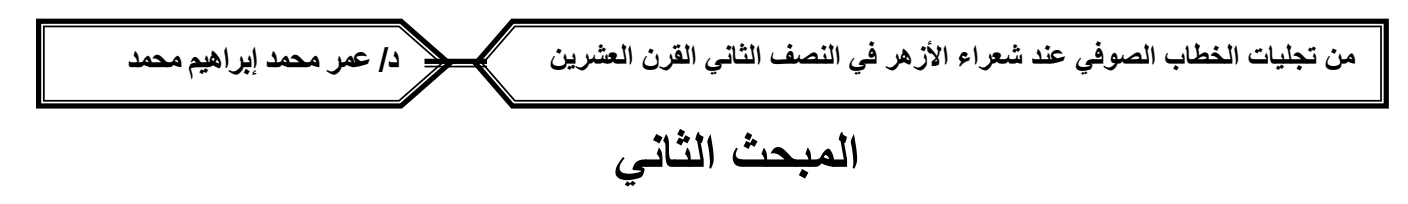

السمات الفنية للخطاب الصوفي عند شعراء الأزهر

المطلب الأول: تجليَّات الخطاب في اللغة والأسلوب

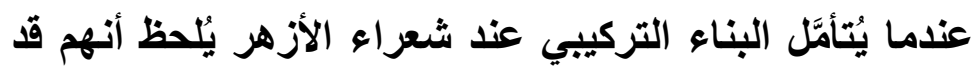

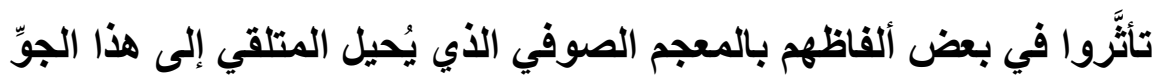

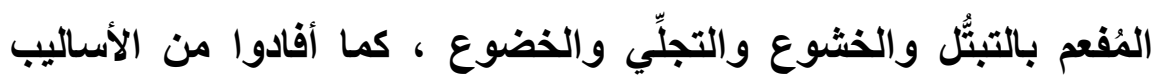
المتنوعة التي تعينهم على ما تجيش به خواطرهم وتجلياتهم .

آثر شعراؤناـومعظم الشعراء المتصوفة_ممن تأثروا غالبًا

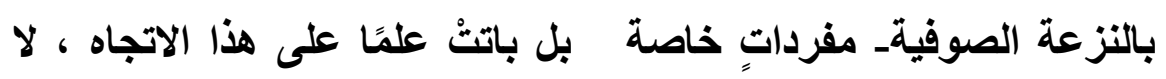

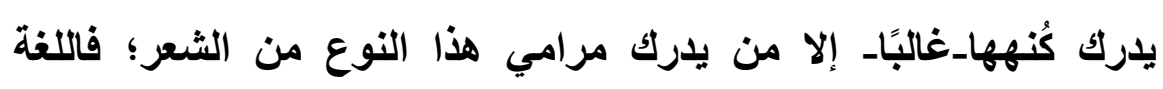

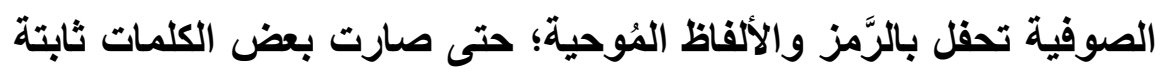

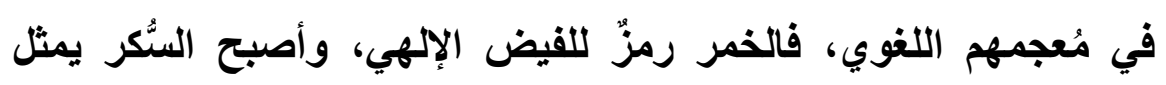

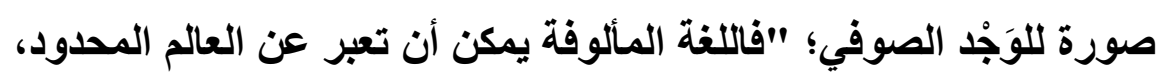

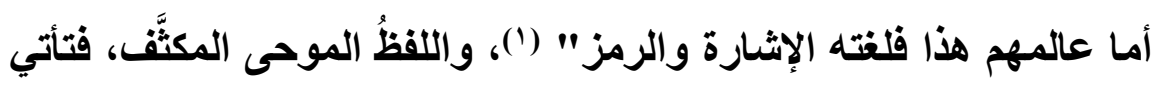

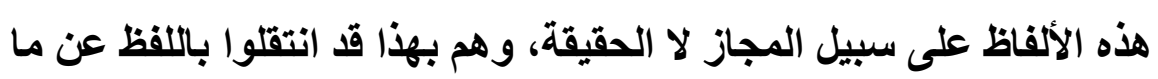

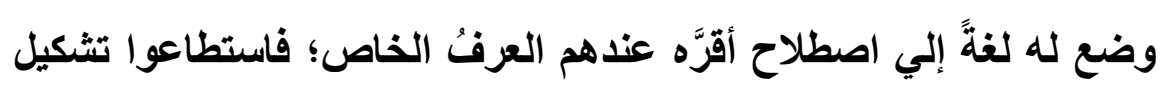
نسقِ خطابيّ مختلف المكونات و والمظاهر.

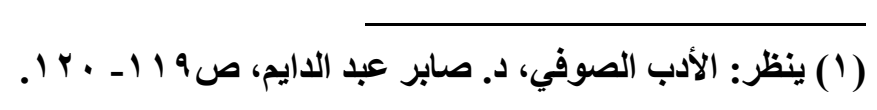


ويأتي دور "التداولية"-والتي أفاد منها النُقَّاد الحداثيون في

مقاربة النّصّ الأدبيّ-لتقوّي الرابطة بين الدوال وما تدل عليه، بوصفها دراسةَ العلاقات الموجودة بين اللّفة ومستعمليها؛ فيدرك المُتتلقي: أنّ هذه الألفاظ المُنتقاة ما هي إلا أقتعة ورموزًا لا تَصدر إلا مِن هؤلاء الذين يقفون

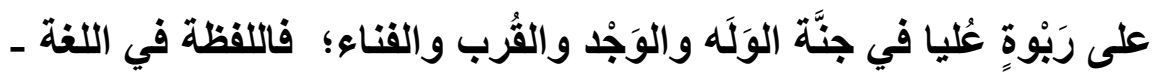
مجردة- تختلف عنها في الخطاب الأي يوجهه المُرسِل إلى مُتلقِ في سياقٍ معين، فلا تنحرف الأفهام إلى غير مقاصد المتكلم ؛ فالحكم على الشيعكما يقول الأصوليون- فرعٌ عن تصوره. ولألك عندما نقف على هذه المفردات المبثوثة في فضاء القصيدة ذات النزعة الصوفية، أو التي تعالقت مع هذه النزعة تعالقًا لُغويِّا : ينبخي الوقوف على مدلولها في اصطلاحهم، وفلسفتهم وإفادتهم من اللغة ومرونتها ، ومكانها من السياق الكُلِّي، لا البِنْيَة الجزئية القاصرة التي لن تحقق فاعليتها ـغالبًا إلا بما يجاور ها ويعاضدها.

فعندما نجد الدال "فني" أو مشتقاته في القصيدة، فلابد أن نذهب إلى ما يحمله من دلالات، فمثَلًا عندما نجد الشاعر الاكتور "محمد العزب" : يتحدث عن محبوبته عبر الدال " القناء" ، فيقول في قصيدةٍ لمحبويته بعنوان : " حبيتي والتراجعات في الخوف" : أفنى فيكـ... يبدعني هواك .... (1) (1) الأعمال الكاملة ، د: العزب ، ص ب9 19. 
وهو دليل على إفراط المحبة نحو محبوبته، إنْ حقيقة أو رمزًا ؛

فأصحاب النزعة الصوفية يرمزون بالمرأة عن الذَّات الإلهية ، فِإذا عَمَّم الحبُّ القلبَ جَرَتْ في عروقه دماء الحُبِّ مجرَى الام ، فأعماه عن كل ما حوله ومن حوله ، فلم يعد في القلب مكان لغيره ، وهذا ما أَطلق عليه الصوفيون الفناء في المحبوب، والأي تعالق معه الثاعر تعالقًا لغويًا ؛ كونه أبلغ وأوجز وأصدق.

ويتجلى عنصر(الاغتراب) عند الشاعر الاكتور "محمد العزب"، غربة القيم والأخلاق التي" تؤدي إلى الإحساس بالفقدان؛ الأي يؤدي إلى الحزن والألم واللوعة والأسى والضياع "(1) ، ينكر هذا التدين المفشوش والورع الكاذب ، فيقول: (الوافر)

\section{دروايشًا نصير وليتَ فينا}

تصوفهم وحلمهم المغامر()

يصف هذا الواقع متكِئا على هذه المفردات الشائعة في المعجم الصوفي ، فمن معاني الارويش: الزاهد / الناسك ، الراهب / المُتعبد، الفقير..."(")؛؛ والتصوف معروفُ، يرغب الشاعر في الاتصاف به حقيقة لا ادعاءً وتزييفًا، فتقترب الصورة وتتضح معالم الخطاب .

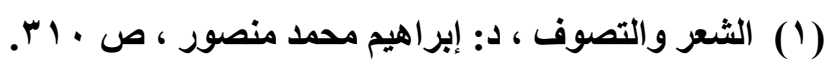

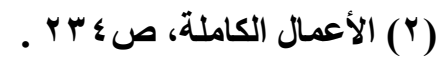

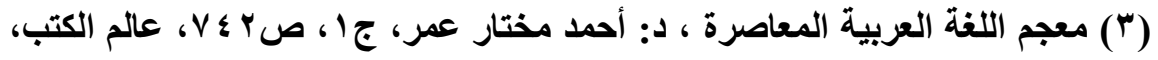

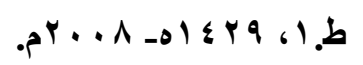


ويستمر الشعراء في هذه المعاناة لكن هذه المرة ليست غربة عن المجتمع، بل غربة القلب والثوق إلى النبي محمد، يخاطب الثاعر الدكتور" صابر عبد الايم" محبوبه في قصيدته" قافلة الغرباء"، يقول فيها (المتدارك) أَحْملُ في شرياني الحُبَّ أجيء إليَكَ على استحياءْ يا من أشرقتَ علينا بشريعتكَ الغرَّاغْ أهواكَّ فأنت سَقيتَ كيانِي معنى البوح وسرَّ الإفضاءْْ

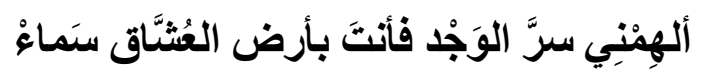
وأراك أتيتَّ إلى العالَم في قافلة الغرباءْ ولأنتكَ أدركتَ الجَوهرَ في عُمق الأشياءْ وتشاقيتَ رحيقَ الحقِّ من العلياءْ (1)

يتحدث الشاعر بلسانِ الفنَّان الذي لا يفتأ ينظر إلى السماء رمز العُلو والصفاء والنقاء، ومصدر الوحي الذي نزل على ممدوحه، والذي أدرك الحقيقة والجوهر، فضلًا عن رحيق المعرفة الأي تنسَّم شَذَاها من علياء الحق، سـاعَدَُ على ذلك شَحْن القصيدة ببعض الدَّوال التي يَكْثُر دورانُها على ألسنة الصوفية، وذلك مثل: (الإشراق، السِّر،الإفضاء، الإلهام، الوَجْد، الرؤية، الجوهر، الرحيق، العلياء،...)؛ وهو ما ألقى بظلاله على روح القصيدة، كما هي دالةُ على روافد الثـاعر وخلفيته المعرفية والتكوينية والدينية. (1) من قصيدته قافلة الغرباء. المرايا وزهرة النور، د: صابر عبد الدايم، ص9ه. 
كما اشتهر التركيب اللغوي-عند معظم شعراء هذا الاتجاه-باعتماده على "الرمز"؛ فدلالته قادرة على التأثير والإيحاء، أكثر من غيره ، فهم متأثرون-غالبًَا- بما هو مستبطنٌ غير ظاهر، ولذلك كان اعتناؤهم بالنفس/ الجوهر، وإفساح المجال لانطلاق أجنحة الخيال، والانفلات من الدوال الوضعية المجردة إلى معانٍ أخرى يتحملها اللفظ بالتفسير والتأويل؛ مما يجعل القارئ يُكِدُ ذهنَهْلإدراك ما وراء الكلام، كما ينطلقون وراء هذا العالم الحسي الأرضي، إلى عالم النور والجمال والجلال.

يعتمد الثـاعر على الرموز الخمرية والأسلوب التلويحي الصوفي؛ ليعبر عن هذه العواطف الاينيّة المشبوبة ، والأشواق الكامنة بين جوانحه، وهو أمرٌ يلعو للاهشة من أن شعراء الصوفية لم يبتكروا لأنفسهم مُعجمًا

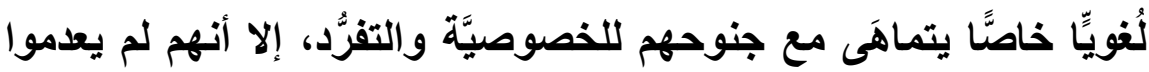
وجود من يدافع عن ذلك(') .

ومن هذه النماذج ـالتي تجنح نحو الرمزيَّةــ ما نجده عند الثاعر الشيخ " محمد متولي الشعراوي، في قصيدته ، " حيُّو المعارف في أطناب نهضتها " : (البسيط)

حفل ككأس الصفا مرنانة الطرب تطفو بها بسمات الثغر كالحبب

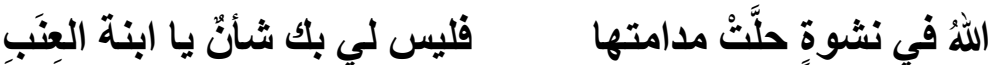
(1) ومنهم الدكتور زكي مبارك الذي قال: " إن الحب الإلهي يغزو القلوب بعد أن تكون

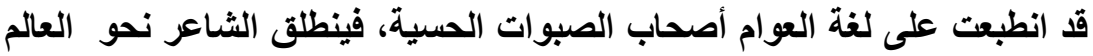
الروحي ومعه من عالم المادة أدوات وأخيلة هي عدته في تصوير عالمه الجديد" .

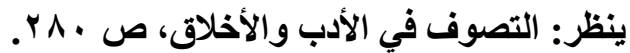


وغمرة الصفو مفراح مشعشعةً تطغى فتصطخب الأعضاء من لجب

لكن جلالة بيت الله قد خلعتْ على الجوارح صحوٌ خاشع الأدب(') ليس للشاعر حاجة في هذه الخمر الانيا؛ فعنده ما يكفيه ويغتيه،

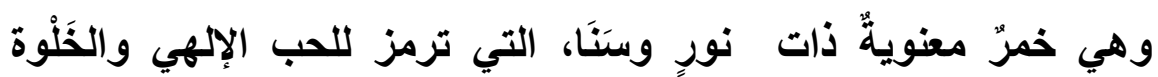
المحبية إلى نفوس المحبين، وقد خشعتْ معها النفس، وحلَّقتْ في الملأ الأعلى؛ فهي خمر إلهية صافية تُسكن الرُّوح، لا أرضية تعطب الجسد،

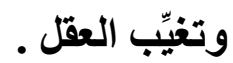

وينشط تدفق التيار العرفاني الأي يحتضن الرمز من خلال نشر هذه الإشراقات الرمزية في رحاب الخطاب الصوفي الشاعر "هاشم الرفاعي"

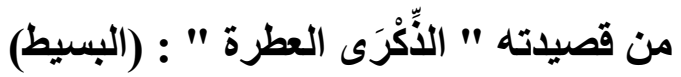

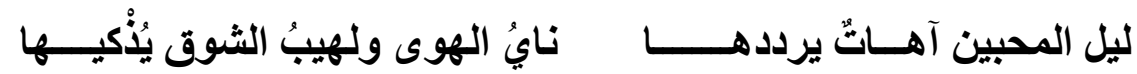

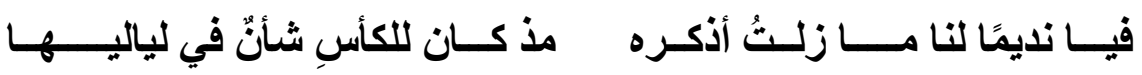

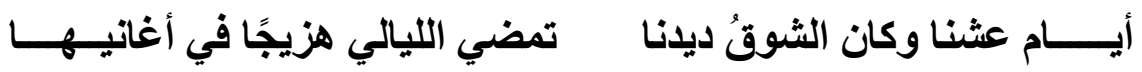
هاتِ اسقتيها سلافا سائغًا عطرا فالنفسُ ظمأى وكأس الروح ترويها(؟) تتميز هذه القصيدة بأنها ذات دلالات تلويحية حافلة بصورٍ حسية

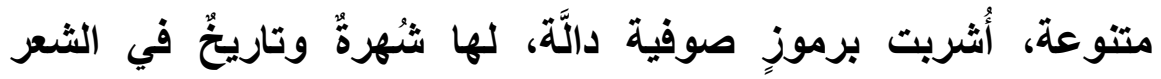
الصوفي، فالنَّاي رمزٌ للإنسان في انقطاعه عن العالم العُلْوي واشتياقه له،

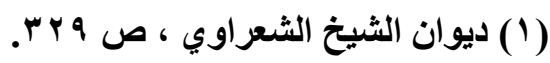

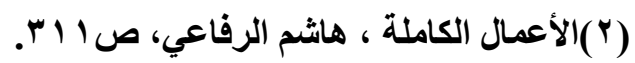


وباعثُ حثيثُ للتأمَّل نحو الطبيعة، فيثير جمالها ومفاتنها، فضلًا عن الرموز المجاورِة له والدالة_أيضًا_على الثوق وَوَصف اللقاء، والأهازيج التي تتظنَّى بالثوق إلى المحبوب، فنجد: ( دوران الكأس، وتعاطي الراح ، والنديم، وسقاية السلاف، كأس الروح...) ، " فالستُكر يرمز للحيرة والوَلَهه، والكأسن يرمز إلى قلب العارف"(') ، فضلًا على أن الخمر- بأدواتها ووسائلها وما يتعلق بها ـ ترمز إلى الحب الإلهي والشوق إلى المحبوب، وكلها رموزٌ متعددة الأبعاد غنيةٌ بالالالات ، وهو دَيْن الصوفية، وعلى الصى رأسهم "ابن الفارض" ، الأي يهيم في الشَّوق والوجْد ، فيرى اللهَ في شواهد الطبيعة وإيقاع الكون ونَغَمِه ، فيقول في قصيدته :" ما بين معترك الأحداق والمهج " : (البسيط)

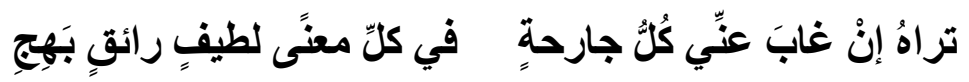

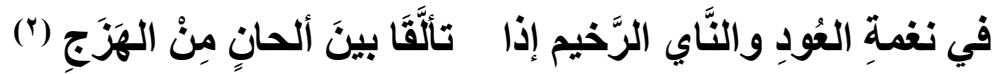

يسيطر الرمز على الصورة الكلية للنص؛ ليكون دليلً على" وحدة شهود المحبوب في حضرة وجوده المتعيَّن بكل ما يتجلى من الصور الحسية والمعنوية في عالم الطبيعة " (") ، في تجربة وجدانية تكثف ما

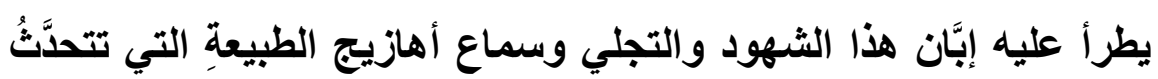
بعظمة الله ، وتكثَفُ بلِيعَ صُنْعه وجميل خَلْقه .

(1) ينظر:الرمز الثعري عند الصوفية،د.عاطف جودة نصر،ص بـآس،دار الأندلس،دار

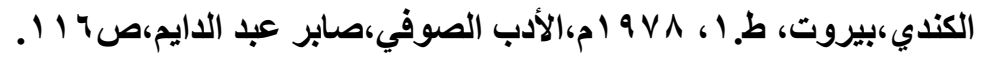

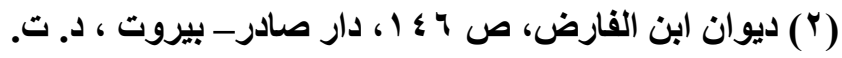

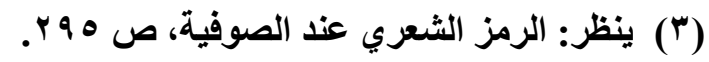


كما نجد عندهم إيثارًا لبعض الأساليب المتنوعة؛ من خلال تراكيب لغوية قادرة- بما تحمله من دلالات_على التعبير عن الرغبات الجامحة والأشواق الكامنة بين الجوانح، فالوضع اللغوي-بموقعه النحوي الظاهر-

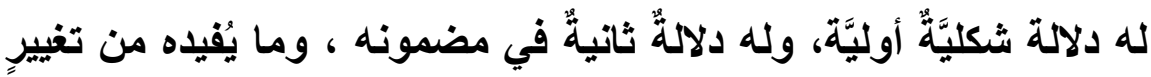
في الصِّفة أو الرُّتبة.

وهو ما استعان به شعراء هذا الاتجاه، من إيثار بعض هذه الأساليب التي يتلقَّاها القارئ، ويعمل على تأويلها وتذوُّقِها وكثف علاقَاتها الخارجية؛ فنجد التعبير بالجملة الاسمية مرَّة وبالفعلية مرَّة أخرى، وبالأسلوب الإنشائي تارةً، وبالخبري تارِّة أخرى؛ تبعًا للأحوال ومراعاةً للمقام، ولهذه الأهمية حفل بها النقاد ب" المنهج الأسلوبي"،أوْ ما يُسمَّى بالأسلوبية (Stylistics)، وهي التي تُعنى بدارسة الأدب من جاتب اللغة، فالمنهج الأسلوبي من المناهج التي شُسهم في " تحليل الخطاب الأدبي بطريقةٍ علميةٍ موضوعية؛ إذ إنه نشأ وازدهر في مجال البحث اللغوي قبل أن يهتم بـه نُقَّاد الأدب " (')

فينتب الشاعز من ألفاظ اللغة وتراكيبها ما يُسعفه على التعبير

عن تجربته، فهو كما قِيل: "الطريقة للتعبير عن الفكر بواسطة اللغة" (؟) فيتفاضل الشعراء بهذا الانتقاء وهذا النسج الذي يتحالف مع عناصر القصيدة الأخرى ؛ فتخرج في ثوبِ قشيب يَسَرُّ القارئين .

(1) الأسلوبية مدخل نظري ودراسة تطبيقية" ، د/ فتح الله أحمد سليمان، صسا، مكتبة

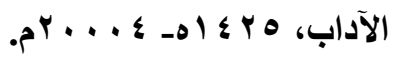

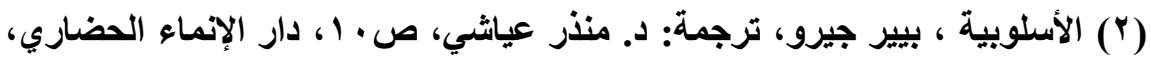

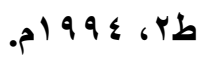




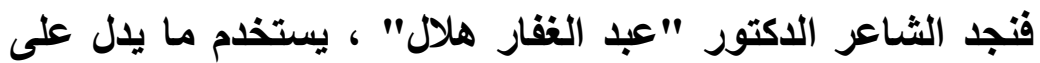
التكثير تارة ، وللنُّبة تارة أخرى، والجملة الاستفهامية مرَّة ، والخبرية مرَّة أخرى ، فيقول: ( البسيط)

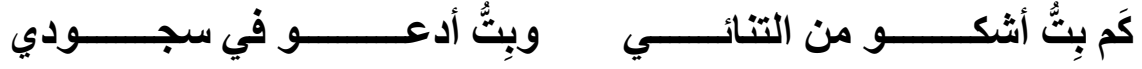

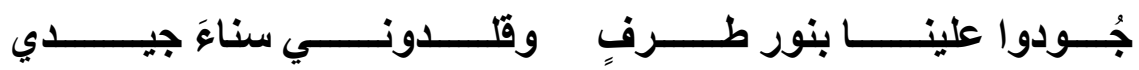

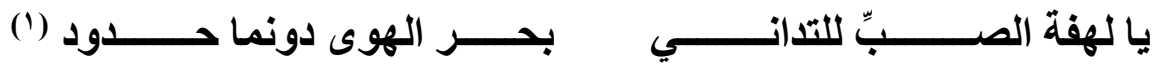
يُنوّع الثاعر في الأسلوب-وقد أفاد من آلية التقابل بين الأفعاللتحمل تلك الشحنات العاطفية، ليستقر هذا الاندفاع والانفعال في وعي المتلقي، بعد أن تشبّع به وجدان المُبدع ولُبِّه، ويفيد الشعراء من آلية التقابل بين الدوال، كي يفيدوا من طاقة اللغة المعجمية؛ للتعبير عن تجاربهم وذاتيتهم، وهو ما نجده مثله عند الشاعر"هاشم الرفاعي"، في قصيدته" ذِكْرى المولد" ، فيقول: (الطويل)

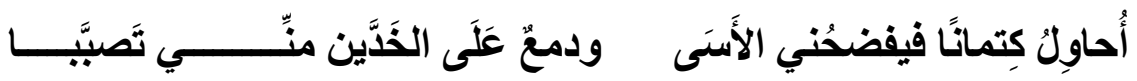

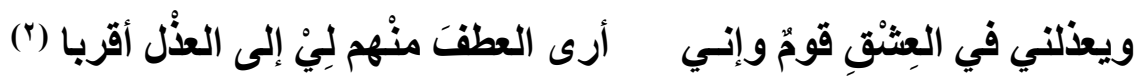
ففي البيت الأول يجمع بين الكتمان والفضيحة، وفي البيت الثاني بين العثق والعذْل، كما قابل بين التعريف والتنكير فعرَّف(الأسى،الخدين، العثق، العطف)، كما نكَّر(كتمان، دمع، قوم)، وهو ما يعكس تذبذب نفسية 
الشاعر، وما لاقاه من الخوف والإثفاق الذي أدرك أنه لومًا لا عطفا، هذا الطباق السياقي كان متوافقًا ــ في الغالبـ مع الطباق المُعجمي؛ مما أدى إلى تكامل الصورة والتعبير عن المعنى المراد، هذا اللومُ عريقُ، ذو نَسَبِ أصيل في التراث الصوفي، يتكاثر العذُل والتعنيف على هذه الأشواق والعواطف الصادقة التي تستوطن قلوب المحبين، وهو ما عبَّر عنه ابن الفارض في قوله : (البسيط)

قُلْ للأي لامني فيه وعنَّنَي دعْني وشأْني وَعُدْ عن نُصحك السَّمِج

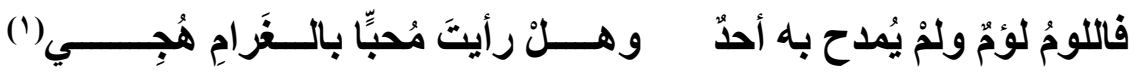
ويفيد الشيخ "الشعراوي" من أسلوب النهي؛ ليمنع صاحب المعروف- الذي يُنافق ويُتملَّق حتى حين- من التخلِّي عنه، والإقلاع عن من فِعْله ، فيقول في قصيدته : " الناس والمعروف" : (الطويل)

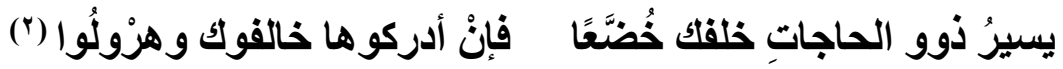
وهو من شِيَم التفوس الضعيفة التي تلكثث وراء المنافع الانيوية،

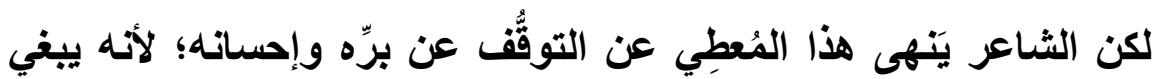
الجزاء من السماء، لا من الأين يأخذون ويَتنكَّرون ولا يشكرون، فيقول: فلا تترك المعروف مهما تنكّروا فإن ثوابَ اللهِ أجزى وأجزلُ

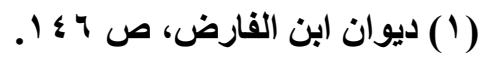

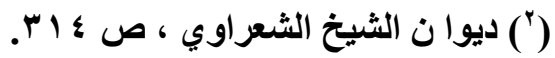


أفاد الثاعر في الشطر الأول بالنهي، وهو إنشايُّ طلبي يفيد الكف عن العمل أو الإرشاد مجازًا، ثم أدخل الفاء على الجزاء في صدر الشطر الثاني؛ ليُفْيا سرعة الثواب المستحق والخير المأمول، " فحق الجواب أن يكون عقيب الشرط متصلًا به ؛ والفاء توجب ذلك " (') . كما أفادوا من المزاوجة بين الخبر والإنشاء، فالخبر لتأكيا حقائق يعتقدونها، وبدهيات يعرفونها، أو تخصيص لشيءٍ أو تتبيه لأمر، والإنشاء ليثير وعي المتلقي ويحرك مخيلته وبخاصة في الطلبي منه، الذي يقتضي ردَّة فِعْلٍ من المخاطب، ولهذا ينبغي استحضار البعد التداولي من خلال الأسلوب الطلبي، فهو يُعدُّ فعلًا إنجازيِّا؛ ينشئه المرسل؛ بغية مضمون محدد

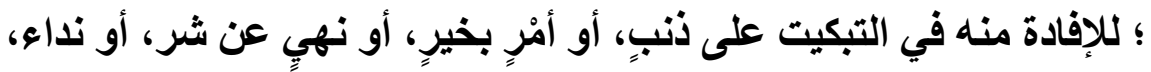
أو دعاعِ ، يقول الشاعر "هاشم الرفاعي" : ( الكامل )

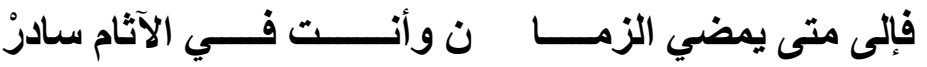

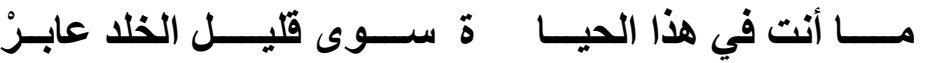
يُّنِّر الشاعر هذا السادر الساهي الغارق في ذنوبه، بأنه عمّا قليل سيغادر هذه الدنيا القانية، متخذًا من الاستفهام التقريعي وسيلة له في البيت الأول ، ثم النفي والاستثناء في البيث الثاني؛ فيكتسب النص معنى التبكيث والتهايد، ثم التقرير والتوكيد، الذي يتضمنه السياق؛ ليوكد هذه الحقائق اليقينيَّة، والتي يتغافل عنها ويتتاسها؛ ليرتاح ضميره ويستمرَّ في غيِّه. .

(1) الأساليب الإنشائية في النحو العربي، عبد السلام هارون، صזه1^ا، مكتبة

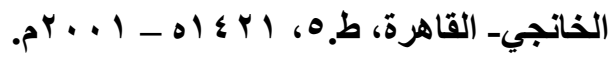




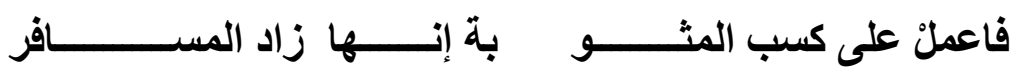

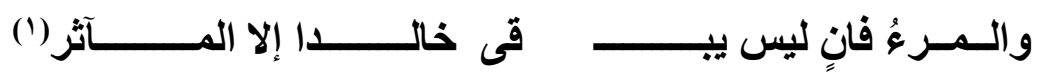

ومنه النداء والابتهال إلى ربه أن يكثف الضر ويرفع الكَرْب؛ فهو سميعٌ

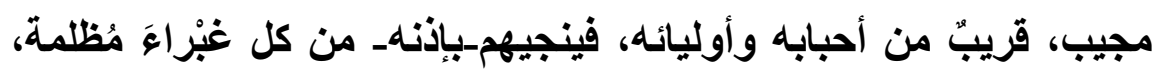
يقول الثاعز الدكتور"عبد الغفار هلال"(") : (البسيط)

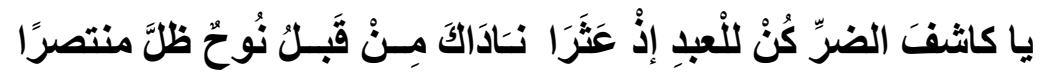

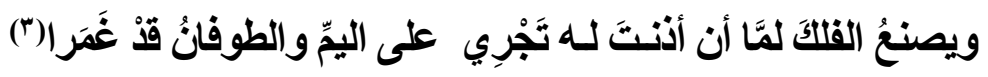

ونصه مُحمَّلّ بحمولاتٍ تراثية مركبة، فقوله:"يا كاثف الضر "،

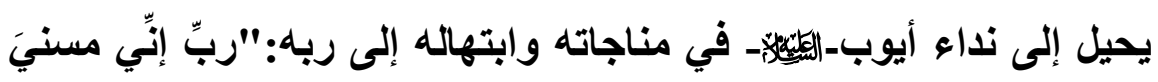

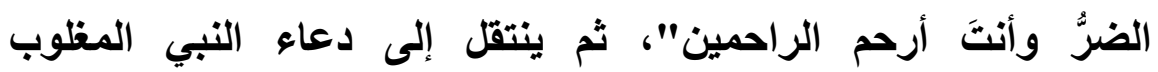

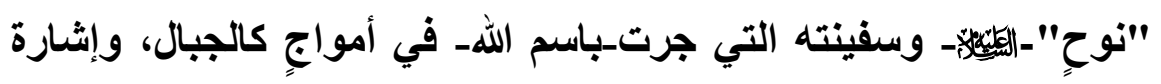

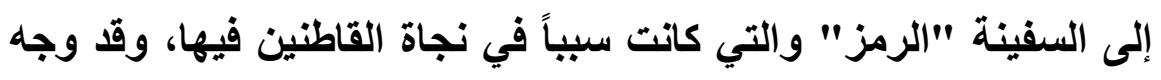

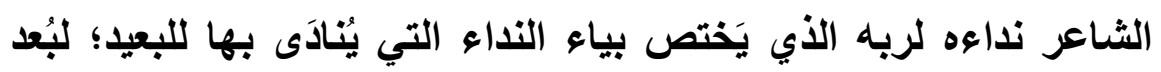

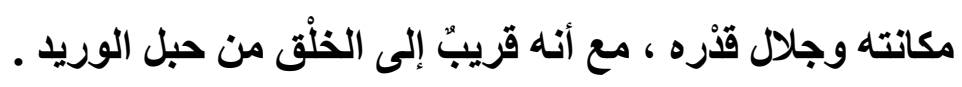

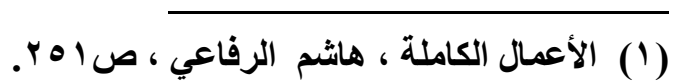

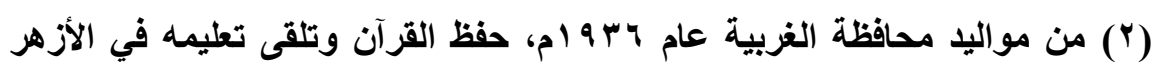

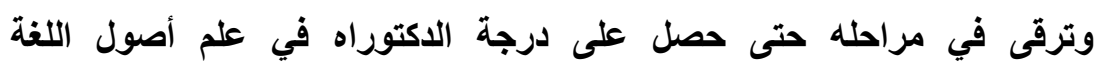

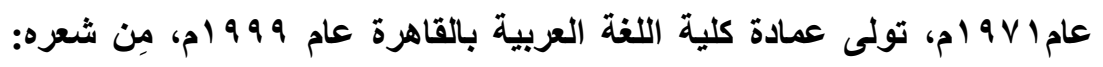

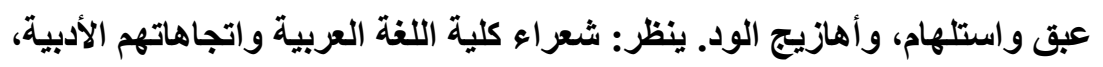

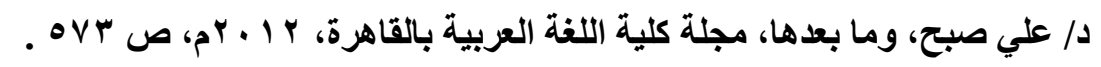

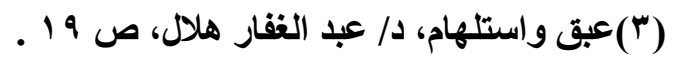


إلى غيرها من الأساليب التي تعمل على اكتمال الصورة بين الدال

ومدلوله، وبين الثكل ومضمونه، فاللغة لا تأتي- في الغالب_عفوًا؛ بل تؤدي وظائف تداولية وسيميائية من خلال هذا الكلام المنطوق، فليدرك المتلقي بعضًا من مراميه ، ويعمل على استيعاب شيعٍ من معانيه. المطلب الثاني: تجليَّات الخطاب في العَتَبَاتِ والنصِّ المُوازي.

تُعدُّ قضية البناء القني في النص الأدبي واحدة من القضايا التي اعتنى بها النقاد والباحثون؛ فمن خلالها تتكثَّف أسرار النص مع كل محاولةٍ لسبر غور القصيدة المنظورة، والغوص في عوالمها الرَّحْبة، سواء في بِنْيَتها الظاهرة أو في بِنْيَتها العميقة ، وهذا ما نجده عند "جيرار جينيت" ؛ فالملحق النصي عنده :" العلاقة التي تكون أقل وضوحًا وأكثر بُعدًا، يُنشئها النصُّ بالعنوان، والعناوين المشتركة، كالمدخل والملحق والتصدير، والتتبيه، والتمهيد، والهوامش، وغيرها من الإشارات الكماليَّة")(1) ؛ فهناك دلالة اختيار عنوانات الدواوين، ودلالة تسمية القصائد، ودلاية تريبها في الايوان ودلالة المقدمة التمهيدية قبيل كتابة القصيدة أعلى صحن الصفحة .

$$
\text { أولاً: عناوين الدواوين : }
$$

للعنوان أهميةٌ كبرى في عملية قراعة النص، فهو الأثر الدال عليه، والمصباح الأي يهدي القارئ إليه، فهو العتبة الأهم في النص الموازي/

(1) ينظر : طروس الأدب على الأدب، جيرار جينت ، ص هـ إ ا، آفاق تناصية، الهيئة

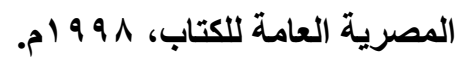


المحيط الخارجي (le paratexte)؛ كما يُعدُّ بابًا للولوج إلى معالم النص، فيكون العنوان مُعمقا لتلك الالالات من الناحية التأويلية دون الإفصاح

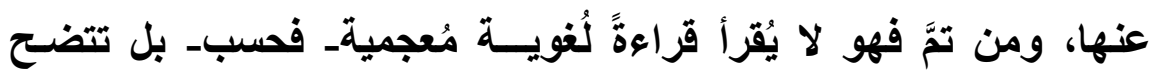
معالمها من خلال القراعة الكلية للنصِّ واستكشاف العلاقات المتثابكة . تكمن أهميته من أنه أوَّل ما تقع عليه عينُ المتلقي؛ لمكانه البارز على الغلاف، مُحددًا هوية الديوان وخطَّ سيره، مما يسهم في توجيه المتلقي، نحو مقروئية النص، واستكناه مضمونهه، سواءً أكاتت عناوين رئيسة للاواوين أو للقصائد المستقلة، أو التي تتفتح على النص داخل القصيدة الواحدة (العناوين الداخلية) التي لها دلائل ظاهرة، وأثرُبارز في إضاءة النص، وشديد التأثير في المتلقي.

ومن أكثر هؤلاء النقاد الأين أولوه اهتمامًا بالغًا: علماء السيمياء،" باعتبار العنوان علامة إجرائية ناجحة في مقاربة النص؛ بغية استقرائه وتأويله"(')، فقد أطلقوا عليه " علم العنونة"الأي يعنى بالنصوص التي تظهر على رأس النص؛ لتدل عليه وتعينه، تثبر لمحتواه الكلي؛ ولتجذب جمهوره المستهدف"(") ، ولهذه الأسباب؛ اهنمَّ به الشعراء عمومًا ومنهم شعراء الأزهر في إبلاعهم لقصائدهم، فكاتت جماليَّة من جماليات تناصَّهم الذاتي والخارجي.

(1) سباق العقبان والنسور - تحليل سيميائي، عطية العمري، مجلة علاماتهو،، صیr 1).

(r) عتبات جيرار جينيت من النص إلى المناص، عبد الخالق بلعابد، صلآ، الأدار العربية

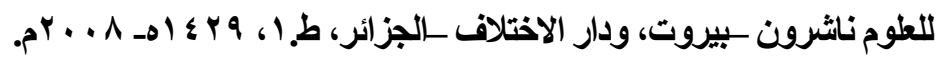

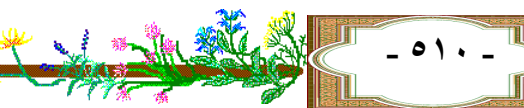


وإنتا نجد بعض دواوين شعراء الأزهر تميل إلى النزعة الصوفية من حيث دلالتها ومنها على سبيل المثال: دواوين: "الله أكبر، للشاعر "عبد الله شمس الدين"، و "الديوان الإسلامي، و"ديوان نغمٌ من الخلا" للاكتور "محمد عبد المنعم خفاجي"، و"عبقٌ واستلهام" للاكتور "عبد الغفار هلال "، "نسمات إيمانية " للاكتور "أحمد عمر هاشم"، و" و" الومضات" للاكتور محمد العربي، وكذلك ديواني: المسافر في سنبلات الزمن "و" العاشـق والنهـر"، للاكتور "صابر عبد الدايم ".

تنفتح العناوين الخارجية على فضاء النص الداخلي(المتن)؛ ليحقق تعميقًا للالالة وإلحاحًا على الفكرة الكُليَّة التي يَتبنَّاها الديوان في جُلِّ قصائده، سواءً أكان العنوان مباشرًا تقريريِّا يدل على النص دلالة ظاهرة ، كالايوان الإسلامي، للاكتور "محمد عبد المنعم خفاجي"، "نسمات إيمانية " للاكتور "أحمد عمر هاشم"، أو "نهج البردة"(1) للاكتور عبد الغفار هلال ، أو مراوغًا يتَّم بالرمز والتكثيف، فيستفز المتلقي ويجعله يُقْبَل بشوقٍ وشَفَف؛؛ ليجيب على تللك التساؤلات ويحل تلك الألغاز التي بحملها

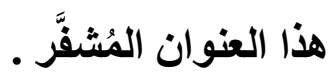

فمثًلًا نجد ديوان"المسافر في سنبلات الزمن"، ذو دلالاتٍ مُكثفة يفتح بابًَا للتأويل، مثيرًا لعددٍ من الأسئلة، فيجيب عليها المتنُ الداخلي، فيكتشف المتلقي أنها عنوان قصيدة داخلية تَحْمِل العنوان ذانته ،مفارقًا

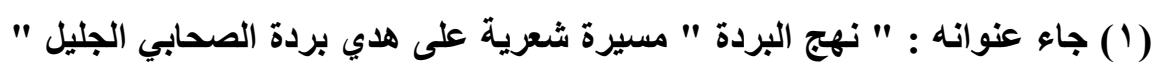

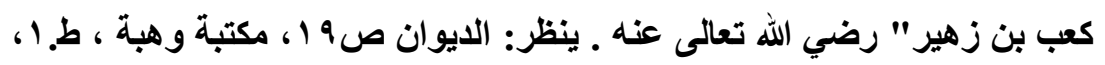

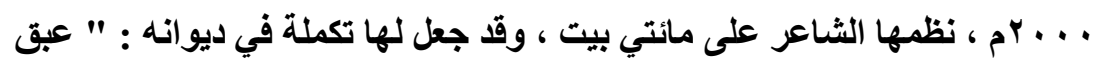

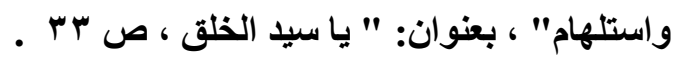


فضاء النص الاخخل؛؛ ليسيطر على عتبة النص الأوليَّة، وهو ما يشير إلى أن الثاعرُ آثرها عن وعي منه وقصد، معلنًا عن نفسه ونزعته واتجاهه وهوايته في فك الأحجبة المنغلقة، وكشف الأسرار وهلم جدار الصمت، فالمسافر يحمل في دلالته التقلب والبحث عن الحقيقة ، والسير في كون الله الفسيح، والنظر في خلق السموات والأرض وما بينهما، لإدراك عظمة آياته ؛ كما أن " السفر والترحال رمزٌ للحياة "(1) ، ولذلك ليس غريبًا أن نجد في المعجم اللغوي للقصيدة مفرداتٍ وتراكيبَ مرتبطة ارتباطًا عُضويِّا بعتبة الديوان الأولى، ثم بعتبة ديوان القصيدة(الأم)، وذلك مثل:( السِّر،

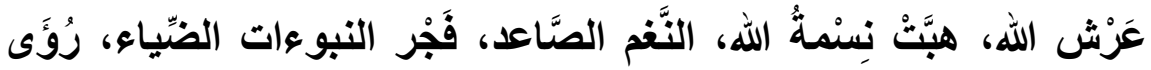
قلبي،...)، الأمر الأي تَميل له الرؤية الصوفية، كما بينته الدراسةُُ في غير موضع؛ وهو ما يُحدث نوعًا من الانسجام والتناغم بين مكونات النص، ثم التوالد والتتامي والإنتاجية والتأويل بين النصِّ والمتلقي.

\section{ثانيًا: عناوين القصائد}

هناك نوعان للعناوين منها ما هو مأخوذٌ بنصه من النص الإبداعي، ومنهم من يترك فسحة للمتلقي بالقراعة التأويلية والاستتباطية من تثلك العناصر الفاعلة الدالة على طبيعة النص؛ فتحدد مرجعيته و ترسم طريقه ، فيمسك المتلقي بأهداب النص وفك شفرته وتأويله ؛ من خلال خلفيته المعرفية والسيميائية لهذه الدوال وتلكك التراكيب . ومن ذلك ما نجده عند الشيخ "الشعراوي" يسرد أحداث هذه الليلة النورانية وما كان فيها من معجزات وتعظيم وهدايا، وهي ليلة "الإسراء (1) ينظر: الثعر والتصوف، د. إبراهيم منصور، صهه . 
والمعراج"، فيزوّر قصيدةً عنوانها"مناجاة واستعطاف(')، يرجو الثفاعة ويُّنِّر بتلك المنزلة التي لم يبلغها أحدُ من قبله، ولا غرو؛ فهي ليلةٌ ـكما قال الشاعر - وحي الجلال وفتنة الشعراء.

فنجد الدكتور العربي"في"الومضات" يجعل الجزء الأول من ديوانه يحمل اسم : " مع المولى عز وجل "مناجاة"(؟) كان هذا هو العنوان الجامع لبعض القصائد ذات التزعة الصوفية التي تهيم في حُبِّ الله والضراعة إليه، والخشوع بين يديه ، والاعتراف بعظمته، والثوق إلى لقائه، وهو ما فعله ـكذلكـ الاكتور"عبد الغفار هلال، في"عبق" واستلاهام"، فجمع مجموعة قصائد- أيضًاـ تحت عنوان" مناجاة"(")، ثم مجموعة أخرى تحت عنوان" يا سيا الخلْق"(() ، يُعدِّدُ فيها شمائل المحبوب، ويتخفَّى بجمال خَلْقهه وخُلُقهِ، والأمر نفسه نجده عند الدكتور "أحمد عمر هاشم" في ديوانه "نسمات إيمانية "، فقد استهلَّ ديوانه بقصيدة "مناجاة"(•) تؤدي هذه العناوين- التي جاءت متصدرة - وظائف سيميائية وتعيينية وإغرائية، تُجبر المتلقي على ولوج المتن؛ لمعرفة ما ينطوي عليه هذا العنوان المُوحي .

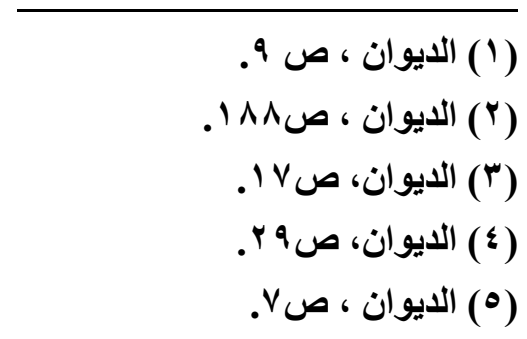


ويتعالق الدكتور "محمد العزب" مع بعض المصطلحات الصوفية

في قصيدته:"حوارية بين المريد والشيخ"(1)، يَنقل حوارًا تخييلِّا بينهما يذأمُ فيه الجمود الفكري والانطواء على النفس واعتزال الحياة ، ضمن روئيته للتمرُد والقفز على المُسلمّات المُهلِكة، يقول: (المتدارك)

يا شيخي الواصلُ لا تلعنْ دنيانا أبدًا

\section{لا تغتز}

فوجودُوَ قِدِّيسًا مر هونُ يا شيخي بوجود الشَر.

قامت هذه القصيدة ـكما هو ظاهر-على سردٍ بين مُرياٍِ وشيْخه، يرفض فيها المريدُ أفكارًا لا تثَّقت مع مقاصد الدين وضروريات المجتمع مُه وواجبات التعايش بين بَبي البشر؛ فما كان التصوُّف الحق مُوجبًا للاعتزال والتعالِي على طبقات المجتمع، بل الأخذ بأيديهم إلى هذا النقاء العُلْوي ودلالتهم عليه، لا ازدرائهم ومَقْتهم، فكان العنوان له دلالة واضحة مباشرة على طبيعة القصيدة على مستوى الشكل الشعري والمضمون الفكري الأي تعالجه القصيدة، فضلًا على التشكيل البصري الأي أفاده استقلال النهي التحذيري" لا تغتز" في سطرٍ منفصل، مما يجعل له دلالة في فضاء النص تساعد على إضاءتذه، تفهمها العينُ القارئة؛ فلم" يعد البُعد البصري بالأمر 
الثانوي في فهم النص، بل بات عنصرًا متميزا في الإنتاج والتأويل" (1)، قصده المنشئُ أم لم يقصده. ثنالثًا: التقديم للقصائد

يعمد بعض الثعراء إلى كتابة نصدِ تمهيديٍ نثريٍٍ قبيل نظمه؛ إشباعًا لخاصَّة نفسه، وإغراءً للمتلقي، فضلًا عن مقتضيات السياق والمقام، فنجد الدكتور" العزب" ـ على سبيل المثال- يُقِّم لقصيدته: "مقاطع من سيرة ذاتية لإبراهيم بن أدهم "، يقول- على سبيل التقديم- : " فلما أحسَّ بالموت قال:" أوتروا لي قوسي"، وتُّوفي وهي في كَفِّه، ودُفن في جزيرةٍ من جزائر البحر في بلاد الروم"(؟)، وهو مقطع دالُّ من عتبة عنوانه المضامين التي يشملها على رؤيةٍ صوفية عميقة، فالاسم المستعار عَلَمُ في الزهد والإعراض عن الدنيا، والدعوة إلى الفضيلة والمُئُل وبُغضه ومقاومته للآفات التي تثيع في قومه كانتشار النار في الهشيم؛ وهو ما يجعل له وظيفةً تداولية تُحيل على النص كُلِّه ، ثم بدأ في نظم القصيدة ؛ لتببئ عما يضمره ذلك التقديم ، فيقول: ( الوافر) أُمارِسن أنْ أكونْ فتتسقط الأشيَاءُ منْ حَوْلِي

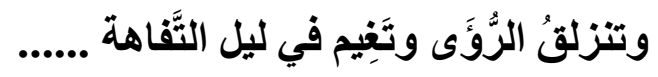

(1) ينظر: الشكل والخطاب مدخل لتحليل ظاهراتي، محمد الماكري، صه، المركز

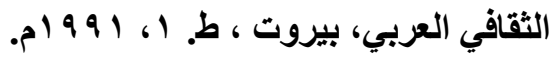

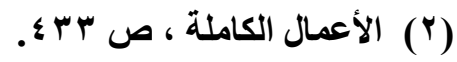


جاء هذا الاستدعاء لهذه الثخصية التراثية والتناص معها

وأحوالها وسيرتها، لقربها ـكما يبدو- من شخصية الشاعر التي وَجَد فيها ضالََّّه ، فكأنها " سيرة ذاتية للشاعر الذي تعددت مراحل حياته يحلم بالثورة على التخلف والفقر ويدعو للحرية والعدل "(') ، هذا التقديم للقصيدة عادة عند بعض الشعراء ، الأمر الأي نجد صداه عند شعرائنا

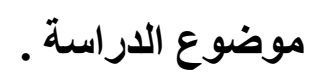
رابعًا: مُقدِّمات القصائد

آثر الشعراء منذ قديم بداية القصيدة برموزٍ دالة؛ لوظيفة سيمئايةة ، فالمقدمة عتبة من عتبات الولوج إلى النص ، والاستهلالُ له دلالته على سائر القصيدة؛ ولذلك اعتنى به كل الشعراء منذ العصر الجاهلي ، كلُّ على إلى حسب بيئته وحالتِهِ النفسيَّة والانفعاليَّة؛؛ دافعةُ في ذللك، كما قال "ابن

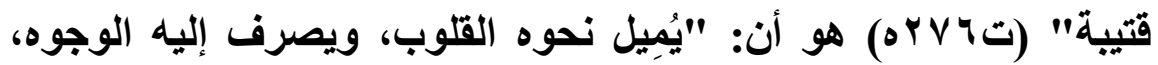

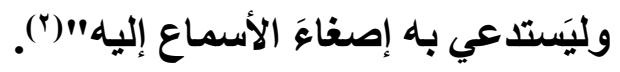

والثُعر الصوفي قائمُ على الرمز والتأويل يسعى من خلاله على

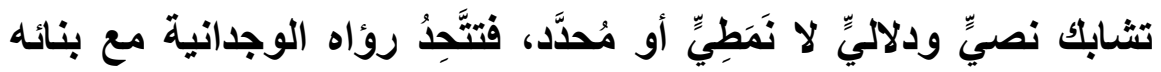
التركيبي والدلالي والتشكيلي؛ فينتظم التناغم والتكامل في الروئية والأداة، وهو ما كان في الاستهلال، فاختاروا لقصائدهم مقدماتٍ تسير في ركاب

(1) تأويل الخطاب الثعري النظرية والتطبيق- محمد أحمد العزب نموذجًا، د: إبراهيم

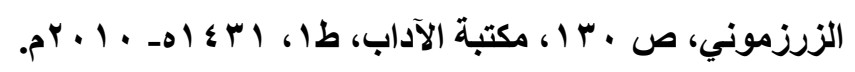

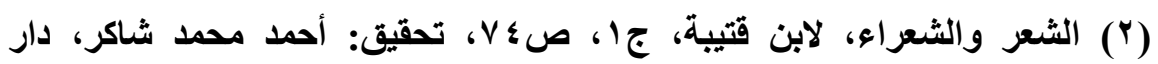

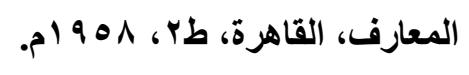


رؤاهم، فجاعتُ بعض قصائدهم تبدأ بالكأس والثراب والخمرة ومجالسها وأَثِرها، هذا الاستهلالُ أمرٌ تراثي غيرُ مستحدث، لكن الصوفية أخذوه وجرَّدوه من هذه النظرة الحسيَّة الاونيَّة، إلى رمزٍ عرفاني خالص، يرمز إلى" لذة الوصل ونشوته"(')، فيهاجرون بأرواحهم إلى الله، ويزعمون أنهم في حضرته يغيبون؛ فاكتفوا به عن كل ما سواه ، وخلوا به ساعةً فكساهم من فيض نوره ، فهذا "ابن الفارض" سلطان العاثقين ، يقول

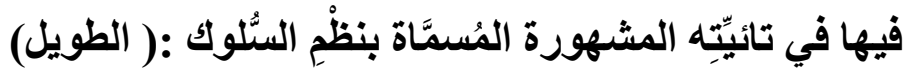
سقتني حميَّا الحبِّ راحةَ مقتَتي وكأسي محيَّا منْ عنِ الحسن جلَّت. فأو همْتُ صَحبي أنّ شُرْبَ شرابهم بهِ سرَّ سرِّي في انتشائِي بنظرةِ وبالحدق استختيتُ عنْ قاحي ومنْ شمائلها لا منْ شمولِيَ نشوتي

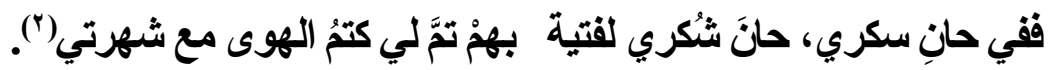
وبالنظر في القصيدة الأزهرية التي تتعالق بشكل أو بآخر مع الروئية الصوفية في شكلها أو مضمونها، نجد أنهم تأثَّروا -بعض التأثرّ-بمطالع القصيدة ذات النزعة الصوفية، ومن هؤلاءع ما نجده عند الشيخ "الثعراوي" في قصيدته ـسالفة الأكر- "حَيُّو المعارف في أطناب نهضتها "(")، والتي مطلعها : (البسيط)

(1) الأدب في التزاث الصوفي، د. محمد عبد المنعم خفاجي، ص ا1 1، دار غريب

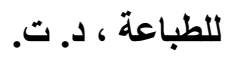

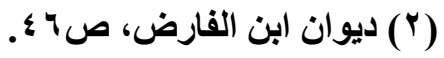

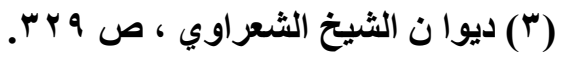


حفلّ ككأس الصَّفا مرنانة الطرب تطفو بها بسمات الثغز كالحبب

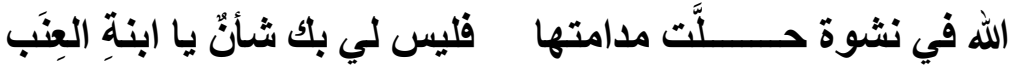

يتعالق العنوان العام للقصيدة مع مقدمتها، ومن ثم مع موضوعها

الكُلِّي ، فهي تهيم في الحب الإلهي والوجْد الصوفي، مستعينًا بأدوات

التشكيل المشهورة عند الصوفية، ومنها المطلع والاستهلال الموحي فضلًا عن البنية اللغوية والتركيبية، والتي تم الإشارة إليها من قبل .

ومن وحي الثيخ" الشعراوي" يتحلث الثـاعر الاكتور"حسن جاد" عن فيوضات الشيخ وخواطره المفسِّرة للقرآن الكريم؛ فأنشأ قصيدته

$$
\text { التي بعنوان" من عَبَِّ التوحيد" (') : (البسبط) }
$$

ساقِ من الخُلا روحى من نداماه ت تفوحُ من عَبَق الفـــدوس ريَّاه

يطوفُ بالكأس سكرى من أناملها ويسكب الرَّاحَ نشْْوَى من سَجَايَاه

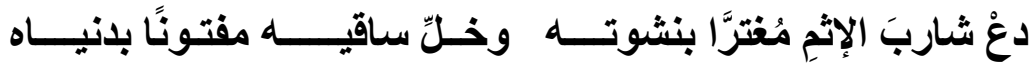

فهاتِها يا نديمَ الروح واستي بها من كرمة الله واتهلّ من عطايـاه.

يحترس الثـاعر في مطلع القصيدة من أن الخمر التي استهل بها القصيدة ليست الخمر المُحرَّمة التي تُذهب العقل؛ بل هي خمرٌ لذةّ للشاربين، تسيلُ من أنهار الفردوس، فهي من كَرْمة الله التي أعدها لعباده الصالحين، فهي الخمر الحلال وكأس العارفين التي يشريون بها شراب

$$
\text { (1 ) شعر حسن جاد جمع وتحقيق ، ص · 1 . }
$$


الثَّوق والحنين؛ فهي تأسِر الرُّوح وتجعلها تحلّق في سماء الحب الإلهي،

$$
\text { يقول: (البسيط) }
$$

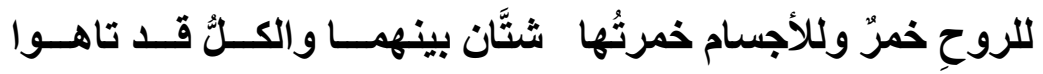

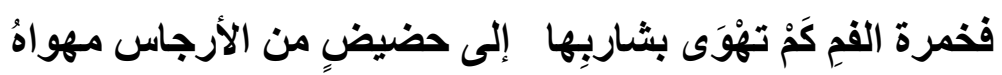

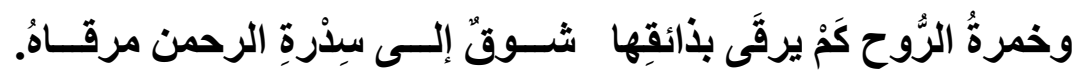

يقارِن الشاعر بين خمْر الأجساد وخمْر الأرواح، فالأولى تهبط بصاحبها إلى الحضيض، أمَّا الثانية فترتقي بصاحبِها إلى المعالي؛ بل تجعل صاحبها يرقى إلى حيث هناك عند سدرة المنتهى، يعدد هذه المعاني السامية ويصف تلك الأحوال والمقامات: فشرابه شرابٌ لا يُغيِّب العقول، ولكن هو غياب المُحبِّ في محبوبه، هذه المرتبةــ كما يزعمون- يغيبُ الصوفيّ عما حوله فيذهل عن الانيا وما فيها، ومَنْ فيها.

وينظم الثاعر الدكتور"محمد العربي" قصيدة لله في ذكرى "الإسراء والمعراج" عنوانها:" صوت ليلة الإسراء" ، بعنوان دالّ يُحدد وجهة القصيدة في البدء، ثم بمطلع متأثرُ بالتقاليد الصوفية ، فالقصيدة عن هذه المعجزة التي منَّ الله بها على حبيبه ونبيّهه ، فيدعو للتخلي عن كل شيءٍ، عَدَا ما يُذكِّره بتلك النفحات والتجليات التي تمنحها

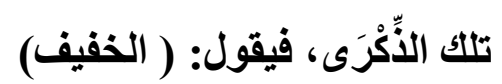

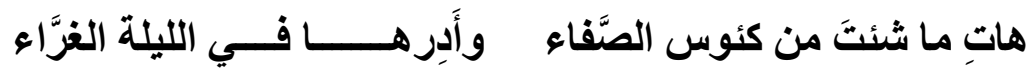

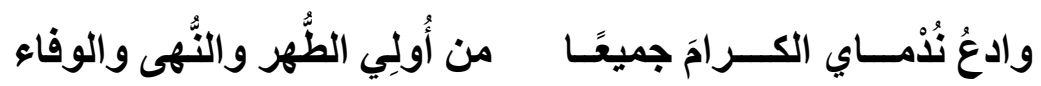




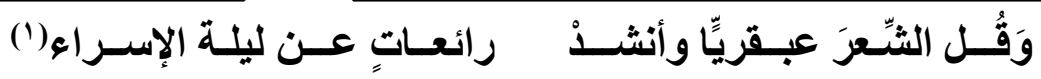

فما إن يقرأ المتلقي هذه المقدمة/ العتبة؛ حتى يدرك موضعها التي تعالجه القصيدة برمتها ، باعتبارها المدخل الطبيعي لسبر أغوارها، والتعرف على وجهتها ومضمونها ، وهو ما يفيده الدراسة الفنية للعتبات والوقف على جماليتها بشكلٍ عام .

وغيرها من العلامات النصيَّة والعتبات المفتاحية التي تثُحُُوغْيَ المتلقي؛ فيستحضر آليات الاستقبال؛ فتنكشف له أطراف الخيوط والعلاقات التتاصية المتثابكة بين التص ومكوناته في بائهله وفي منتاه، بَّْ كل أنواع التعالقى . المطلب الثالث: من تجليّات الخطاب في الموسيقى والإيقاع . يشكل الإيقاع والموسيقى بُعدًا دالِّا في مقاربة النصوص مع غيره من الأبعاد التعبيرية والتثكيلية الأخرى والتي تثاركه في بنائها؛ لما يشكله من أثرٍ في النَََّس وَوَقْعِ على القلوب، بيد أن للأوزان الثعرية ـ التي تشكل حجر الزاوية في الإيقاع- مَيْزة خاصة بالشعر منذ القديم، وهو ما يدلنا على أن العرب اعتنوا اعتناءً خاصَّا بالموسيقى والإيقاع؛ وأثر ذلك على أذن المتلقي وسمعه؛ " فالجانب السمعي له وجهتان : جهة فسيولوجية خاصة بأعضاء السمع ، ووجهة عقلية خاصة بالعملية النفسية التي تتبع إدراك السامع للأصوات"((ז)، وهو ما حدا بالدكتور" زكي

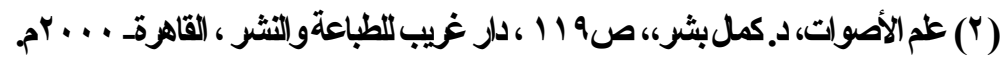


مبارك" بتخصيص مبحث في كتابه عن" الموسيقى والغتاء" (')، في الفكر الصوفي، ولا ريب في ذلك ؛ فالأذن تعثق قبل العين أحيانًا .

ويبلغ اهتمام الثعر الصوفي بالإيقاع ذُرْوته؛ نظرًا لاعتمادهم على الرمز في شتَّى الأنواع التعبيرية والإيحائية، فهذا الإمام"أبو حامد الغزالي" يقول في إحيائه: "من لم يحركه الربيع وأزهاره ، والعود وأوتاره فهو فاسد المزاج ليس له علاج " (") .

ولهذا نجد أن القصيدة الأزهرية ذات الاتجاه الصوفي تلتزم -في الغالب- الثكل الخليلي / العمودي، التي تعتمد على البحر الواحد والقافية الموحدة ، وهو ما يأخذ بلبِّ المتلقي ويَأْسِر سَمْعَه، مع وجود هذه المتوالية النغمية التي تُحقق انسجامًا ينضاف إلى الوسائل الأخرى التي تُشكِّل جماليَّات القصيدة ، وهو ما يحاوله بعض النقاد من دراسة علاقة القافية بالوظيفة الدلالية فضلًا عن دلالتها السيميائية والصوتية وعلاقتها بالبنية الكلية للنص.

ومن ذلك ما نجده في قصائد الثعراء: ( محمود هاشم، محمد عبد المنعم العربي، عبد الغفار هلال، هاشم الرفاعي، ...) فقصائدهم تكاد لا تتجاوز الشكل الكلاسيكي/ التقليدي الذي ينتظم إيقاعه في القصيدة كلها ؛ الأمر الذي ألقى بظلاله على بِنية النص الجامعة ودلالتها على الحالة 
الشعورية للمبدع ، فمثلا نجد الثاعر "هاشم الرفاعي" في قصيدته : "

$$
\text { وحي المولا" : يقول: ( البسيط) }
$$

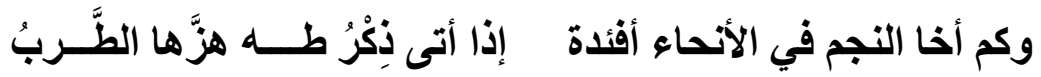

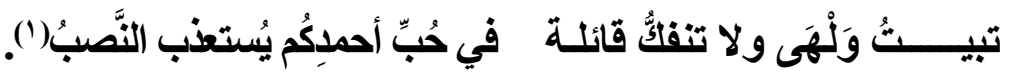

تقع القصيدة على تفعيلات بحر"|البسيط التام"، والأي يستطيع استيعاب التجربة ؛ لاتبساط حركاته التي يشملها فضلًا عن ما يضمره من إيقاع نغمي أخَّاذ؛ فقيه " بقية من وزن بحر "الرجز" وهي ذات دندنة تَمْنع نَغَفَه أن يكون خالص الاختفاء وراء كلام الثَاعر، وكامل النزول منه بمنزلة الجو الموسيقي الأي يكون من الشعر كالإطار من الصورة، ولا يكاد روح "البسيط" يخلو من أحد النقيضين :العنف أو اللين" (Y)، ملتزمة حرف (الباء) كرويٍٍ لها في سائر القصيدة ، التي يتميز بالقوة والجهر والطلاقة والذَّلاقة، مما يخلق جزيسًا مناسبًا لأجواء القصيدة التي سيطر عليها مفردات تموج بالعذوبة والليونة؛ لتناسب الجو العام للقصيدة، آزرته القافية المُطُلقة التي تعمل على تفريغ شحناته الشعورية عبر إطالة الضَمَّة التي ترمز للمباهاة والافتخار، منتقلًا من بيتٍ إلى بيت حتى نهاية القصيدة

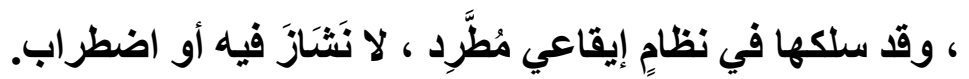

وغيره من النماذج التي تجْنح نحو الإيقاع المنتظم اللُتَّحد بنغماته، الملتزم بوحدة إيقاعه ؛ فينشأ عن ذلك جمال الإيقاع وحلاوة الترنُّم، فيسنهُل -

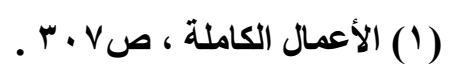

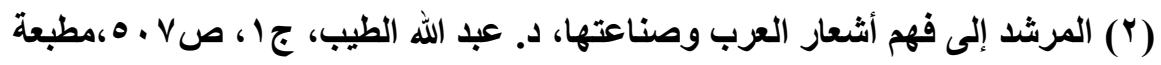

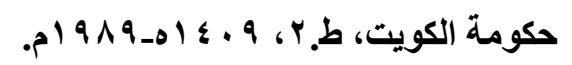


على إثر ذلكـ حفظه وروايته ، فأكثر أشعار الصُّوفيَّة تدور على الألسنة وتُلقَى شفاهة في المجامع والمحافل، وبخاصة في ذكرى ميلاد التبي كئسة، وهو ما يصبو له شعراء الاتجاه الصوفي، ومن أمثلة ذلك قصيدة " المولد النبوي" للشاعر الثيخ " محمود هاثم"، والتي منها بيث المديح الثهير : (الكامل )

عذرًا رسولَ الله إن قصَّرْتُ في وصنفٍ فِإنَّ جمالَكم لن يُوصِفَاِ (1)

يتموضع هذا البيت في قصيدة على النسق الإيقاعي ذاته، التي تمتاز بنظامٍ صوتي مُحْكم على وزن بحر"الكامل" الأي حمل مع حركاته الوفيرة صدقَ الانفعالات المبثوثة في فضاء القصيدة؛ وهو بحر- كما يقول أحد

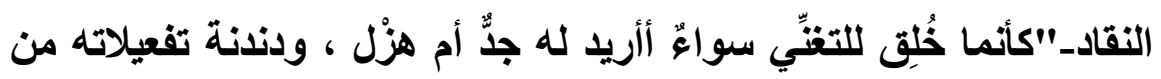
النوع الجهير الواضح الذي يهجُم على السامع مع المعنى والعواطف والصور، حتى لا يمكن فصله عنها بحالٍ من الأحوال"(ب)، مؤثرًا حرف الروي (الفاء) الأي يمتاز -ضمن ما يمتاز- باللهمس الأي يَنْمَح بجريان الأنفاس الممزوجة بالأشواق والحنين عند انتهاء البيث؛ مُعبِرًا عن الأشواق الكامنة التي يمتلأ بها صدر الشاعر؛ فيتوافق الإيقاعُ مع المضمون الذي يَثِي بصدق التجربة، فيتقبلها المتلقي بِقَبَولِ حَنَنِ، وينزلها من نفسه منزلةً

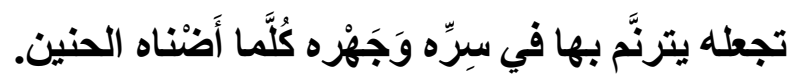

ولهذا عمد الثعراء- وبخاصة أصحاب التوجه الصوفي- إلى العناية بالقافية، باية من اختيار حرف الروي ؛ فلكل حرفٍ صفاته وخصائصه ودلالاته ، مرورًا بما يُجاوره من حروفٍ سابقة أو لاحقة، ثم بحركته

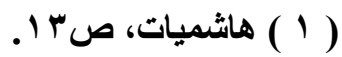

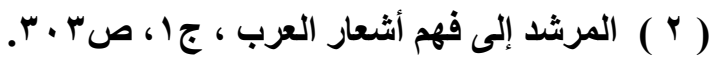


الموحية ـغالبًا فالكسرة توحي بالتواضع والانكسار، والضمة يُشتم منها الإبَاءع والثََّمَم، والفتحة قـ ترمز إلى الثموخ والاستعلاء ؛ كون الروي/ هذا الصوت المُكرر أحد أعمدة القصيدة المُقفاة التي لا تتنظم إلا به، فضلًا عن كثفه لتجربة الثاعر وعاطقته وانفعاله النفسي الأي سيطر عليه إبَّان

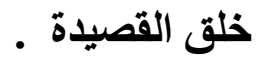

ويظهز ذلك في قصيدة "يا سيد الخلق"(') للاكتور "عبد الغقار هلال" التي نظمها معارضةً للبردة الأولى (r)، التي يقول مطلعها : (البسيط) يا سيد الخلق في خَلْقِ وفي خُلُقِ هذا لساني أغرتْه التراتيلُ والقصيدة تنهج نهُج "كعْب" في الغَرَض والوزن والموسيقى، على بحر البسيط الملائم لوصف الثمائل والمديح، مُؤْثرًا القافية المُطْقة القوية التي تساعد على نقل الحالة الشعورية التي تعتمل في نفسه، عبر حرف اللام/ الروي المُتشبِّع بضمَّةٍ مُوحيةٍ رامزة ، والأي بَنَى عليه قصيدته الضاربة في الحب والشوق المُحمديّ أبلغ صوره ـ

$$
\text { الموسيقى الداخلية }
$$

الإيقاع الاخلي خفيٌ غير ظاهر في الغالب الأعم ؛ لأنه من الممكن إدراكه، لكن معرفة الأسباب التي تقف خلفه تحتاج لنظرِ وتريُّث، سواء أكاتت حروف مد شائعة، أو حروفٍ بعينها لها سمات وخصائص كالجهر والهمس أو

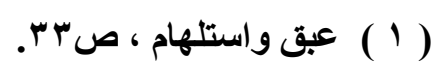

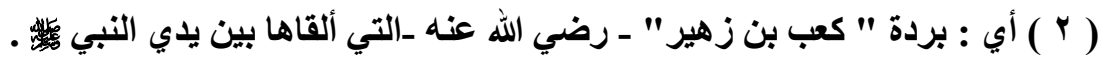


الثدة والرخاوة أو غير ذلك، أو ظواهر مرئية تدركها العين كأسلوب الكتابة أو علامات الترقيم ، أو إيثار مفردات بعينها لها دلالات معينة. كل ذلك - وغيره - يتضافر؛ ليصنع إيقاعًا مؤثرًا في بنية الإيقاع الكلية للنص ؛ فتنسجم الألفاظ مع المعاني في الغالب؛ لأن الثاعر يحاول أن "يتخيَّر من قاموس اللغة أصلح الألفاظ لمعانيه ، فيوفق في اختياره

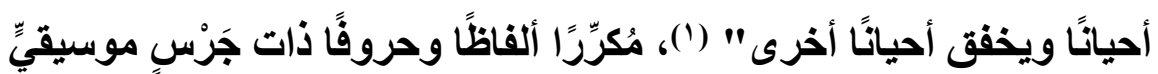

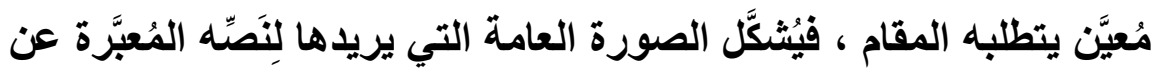
عاطقته وتجربته ومعاناته أيّما تعبيز، الأمر الأي ينبغي على الناقد استخراجه ومعرفة دلالاته على السامع والمتلقي ومكانة التص والحُكم عليه بالجودة أو الرداءة ، فالخطاب الشعري ذو بُعْد تداوليِّ ، يُنْتَج ليُتَتَََّى . ومن ذلك ما نجده عند الشاعر الاكتور "محمد العزب" في قصيدته "مقاطع من أغنية وداع إلى المدينة المنورة"، يُصوِّر فيها ما جاث في

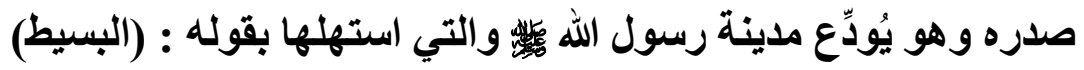
حبيبتي ها هو الرُبَّانُ يقتربُ وها شراعي على الأمواج ينتصبُ حبينتي صدِّقيني في رُبَا وطني وبعد أحضانك الملأى سأغتربُ لس فيك عثث جميل كنتُ أكثُبُه

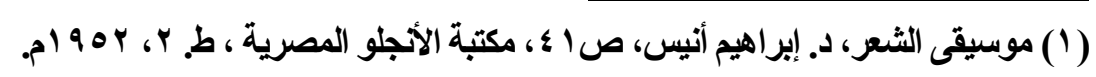




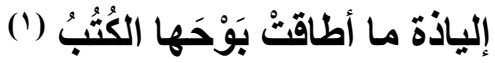

وبمقاربة هذه القصيدة نجد أنها تميَّزت بموسيقى داخلية خاصَّة دلَّت على عاطفة الثاعر إيَّان وداعه لمحبوبته/ المدينة، فقد قام الثاعر بتكرار ألفاظٍ وحروفٍ لها أثرُ على غرض القصيدة وموضوعها العام، ومن ذلك تكراره للعثث ومشتقاته أربع مرات في القصيدة، التي تتحدث كلها عن حُبِّ تَملَّك الثَاعر فسيطر على كل مشاعره وأحاسيسه، هذا الحُبُّ هو ما أرغم الشاعر على ذكر هذا الدَّال (العثق) ومشتقاته في كل دفقةٍ شعوريةة ، ليبيِّن مدى العثق الذي انتابه ، وَوَقْع الوداع في قلوب المُحبين - وبخاصةٍ بعد ما كان بين مسكنه وبين قبر النبي الكريم خُطواتٍ معدودة، كما جاء في القصيدة ـ فضلًا عن الأثر الأي يتركه تكرار هذه الأصوات من إيقاعِ موسيقيٍٍ يطرب له الوجدان ، وتستمتع به الآذان ، وهو ما يظهر كنلك في إفادته من الجناس (الأبي جاء سلسنًا غير متكلف، في قوله :(البسيط)

$$
\text { أرجولِِ كُلُْ المَدَى حَرْبٌ لأجنحتي }
$$

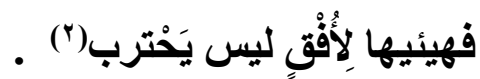

وفي القصيدة نفسها نجد- كذلك- ملمحًا موسيقيًا داخليّا مؤثرا ، وهو تكرار حرف"الشين" بصورة لافتة في حشو المتن، مثل:(شراعي، عشق، يمشي، الشهب، شاطئاه، رموشي، أخشى، الواشون، شوهوا،

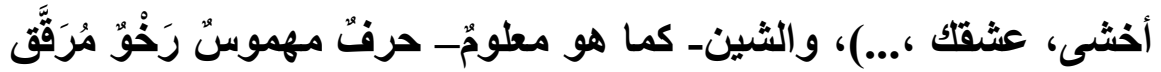

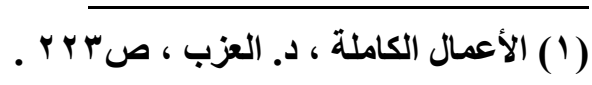

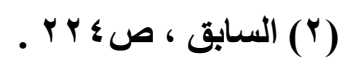


أبرز صفاته التفشِّي والشُّيوع والاتساع ، وهي صفات يحاول الثاعر إلصاقها لأشواقه التي يحملها قلبُه لهذا المكان المقد، هذا الورود والثيوع للحرف الواحد يعمل -مع غيره من الأدوات الأخرى- على إغناء النص الشعري من حيث التناغم الاخلي فيُشري المعنى، ويؤثر في المتلقي، فضلًا عن وظيفته الجمالية والفنية.

كما أكثر من ورود حرف " السين" في القصيدة ، ومن ذلك : (رسمت، يحسن، سألت، يحسن، تمسحي، سارية، انتسب، أسلمت،سحب، راسليني، تنسحب، سيف، نستريح، نتسكب، أينسى،...) والسين من حروف الصفير والهمس، وهي رخْوة تفيد التنفيس، أتَى بها الثَاعر بهذا الكَمْ ؛ ليفيد منها في رَسنم الصورة الجامعة للقصيدة الثََّّكية البُعْدَ والفراق، فحين تثردَّدُ هذه الأنغام الناشئة من تكرار حرف "السين" بموسيقاه الظاهرة : تزداد جمال موسيقى البيت وحُسننه، وبخاصة حين ينجح الثاعر في توزيعه على الكلمات دون مَثقّة أو تكلُّف، فتستريح الأذنُ إلى القصيدة ، وتُقتبِلُ عليه طائعة ؛ لعذوبة إيقاعه وجمال نغَمِه. وعلى نهجـه سـار الـدكتور " صـابر عبــ الـدايم " في أثــواقه الحجازيَّة ، من إيثار حَرْفي (الثين والسين ) في قصيدته التي تَفْطر حُبِّا وشوقًا إلى بيث الله العتيق، فيقول: (الطويل) من النيل شرياني إلى البيت يمتثُ وشوقي إلى أم القرى ما لله حَدُّ

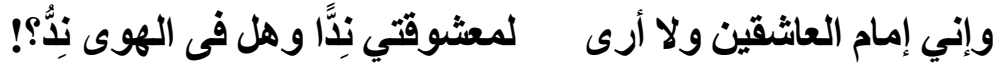

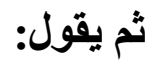




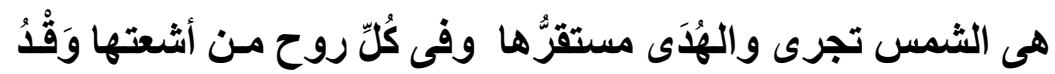

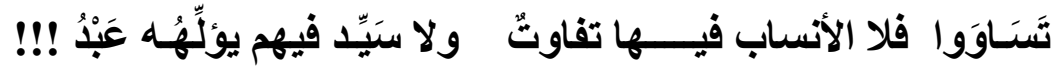

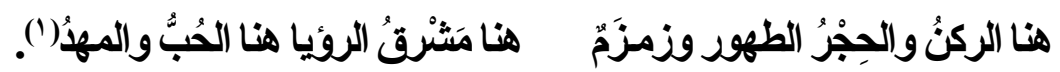

تناثُر الحرفان في فضـاء القصيدة بهذا الكم جعل لها بعدا موسيقيًّا دالّاّا، ثم تكراره أكثر من مرة ؛ فيعمل على إضفاء جوِّ موسيقيِّ لـه دلالـة

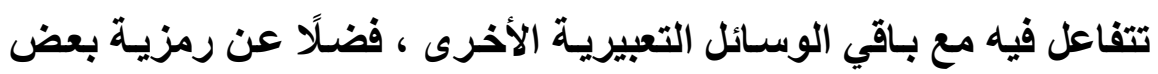
الحروف عند الصوفية ، كما قالوا عن "باسم الله" مثلًا : " فالباء " ترمز

عندهم " إلى بهاء الله، والسين إلى سنائهه ، والميم إلى مملكته" () .

إلى غيرها من الحروف التي يلجأ إليها شعراءُ الاتجاه الصوفي- في

وعي منهم أو غير وعي- إلى الاستعانة بها ؛ لما قد تحمله من رموزٍ وإيحاعاتٍ تجعل لها دلالة في حَدّ ذاتها، بالإضافة إلى النفم الصوتي التي تحدثه الحروفن، وعلاقتها بالتيار الشعوري والنفسي في مسار النص الشعري.

وهو ما أسَّسه "النَّقَّري "(") في كتابه" المواقف والمخاطبات" بقوله: "وقال لي: إذا نطقتَ بالحرف رددته إلى المبلغ الذي تطمئن به، فيسري بحكم مبلغه في الحروف فيسري إليك حكم السوي، وقال لي: الحرف

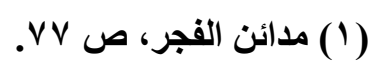

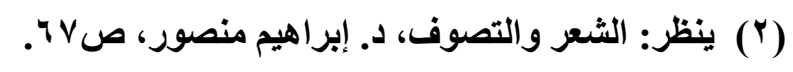

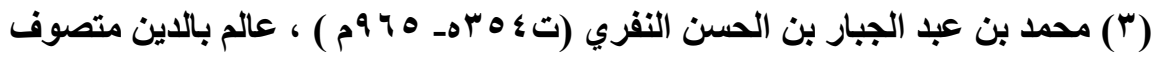

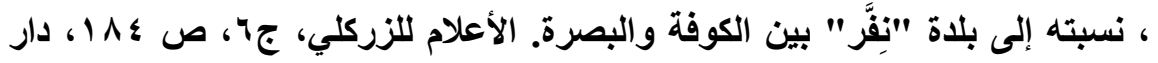

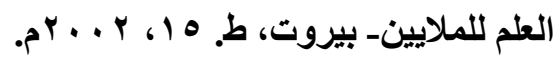


الحسن يسري في الحروف إلى الجنة، والحرف السوء يَنْري في الحروف إلى النار " (1) ، وإن كان فيه بعض مبالغات إلا أنها لا تعدم إشارات ودلالات إيحائية ، فضلًا عن موسيقاه وإيقاعه الأي يجعل له مَيْزة عن غيره مِنْ باقي حروف الهجاء ؛ فالأصوات ـ كما يقول الدكتور إبراهيم أنيس- " تهذف إلى نوع من المماثلة أو المشابهة، ليزداد مع مجاورتها قربها في الصفات أو المخارج، ويمكن أن يسمى هذا التأثر بالانسجام الصوتي بين أصوات اللغة ، وهذه ظاهرة شائعة في كل اللغات بصفة عامة " () . كما عمد الشعراء إلى الإفادة مما يُسمى القوافي الاخلية ، التي تعمل عمل السجع في النثر ، وهو ما يجعل لها أثرًا موسيقيًا مؤثرًّا، ومنه ما جاء في بردة الشاعر الدكتور " أحمد عمر هاشم" ، يقول : (البسيط)

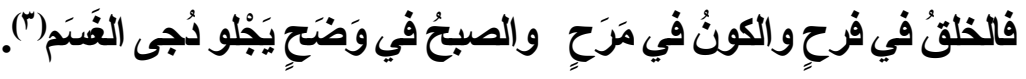
وهذا البيت متعالق تعالقًا إيقاعيّا مع بيت " البوصيري " :

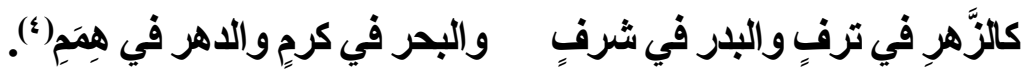
عارض الثاعزُ المعاصر البيتَّ التراثي معارضة في الروئية والأداة، عكستها المحاكاة الأسلوبية على مستوى الصياغة؛ فأثُُْر الحُبِّ في نفس كِلَا

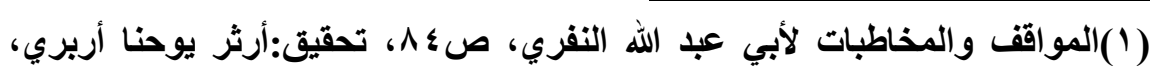

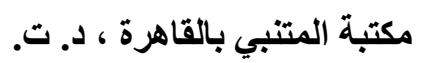

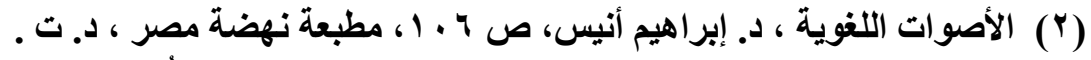

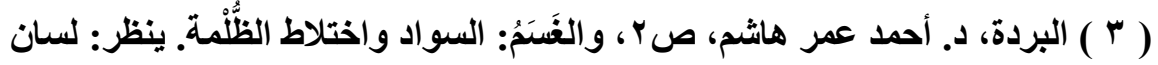

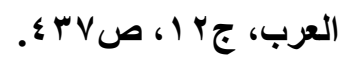

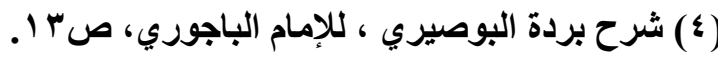


الثَاعرين واحد، فلم يجد شاعرُنا بُبِّا من الصَّوغ على المنوال نفسه، وبخاصةٍ في التقسيم الاخليّ، والموسيقى والإيقاع بثكلٍ عام، للالالة على تعلقه بالقصيدة وتسلطها الظاهر عليه .

وغيرها من الوسائل والأساليب التي يتكئ عليها الثسعراء؛ لنقل ما يعتمل في وجدانهم وعقولهم، فاللغة بدلالتها الوضعية المجردة قاصرة عن نقل كامل التجربة الثعورية للشاعر، فيبحث عن مُعيناتٍ أخرى كالصورة والرمز والعتبات والموسيقى، وغيرها من الأدوات؛ فتتجاوب الرموز وتتنادى العناصر لإبراز كامل التجربة التي قد يتعمدها المبدع أو تأتي عفو الخاطر ، ولكنها لا تخلو من تأويلٍِ يختلف باختلاف وَعْي المُتلقين . 


\section{الخـاتــــة}

وبعد هذا الثَّطواف حول النماذج الشعريَّةٍ الأزهريةٍ ذات النزعةٍ الصوفيَّةٍ التي حلَّقته في فضاء الروح، وجنحتْ نحو الوَجْد والثوق والاستبطان، وقارعتْ الماديَّة المَقِيتة، ودعتُ إلى التأمُّل في الكون والتفس

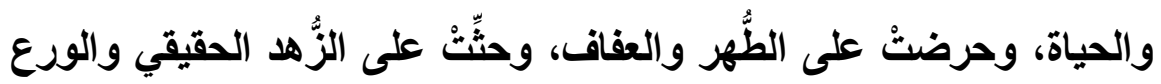
الصادق،يُمْكن أن نَذْكر بعضًا من التتائج والاقتراحات التي توصَّل البحث إليها .

$$
\text { أولاً: التتائج : }
$$

- - هناك صِلَات وثيقة بين التصوُّف والشعر، فكلاهما متعلقُ بالعاطفة والرُوح والوجدان، والتحليق في سماوات الرمز والقناع، والحس والتأمل، ولهذا كان الثعر من أنجع الوسائل لتوثيق التجارب والأحوال والمقامات، كما في أشعار " رابعة العدوية "، و"الجنيد"، و" ذو النون المصري"، و" ابن منصور الحلاج"، و" أبو حفص بن الفارض"، و "محي الدين بن عربي" ، وغيرهم . - كان الشعر الأزهري عمومًا وبخاصة في النصف الثاني من القرن العشرين- مدة البحث الزمنية- وثيق الصلة بالتجربة الصوفية بسبب عوامل عدة، أبرزها: المكونات والروافد التي استقوها عبر مشوار حياتهم، ولذلك نجد في منجزهم الإبداعي قصائدَ ذات حمولاتٍ تأمليَّة،

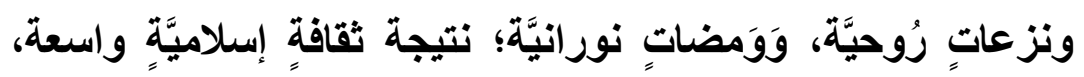
وأزهريـة مُتشبعة، وشـاعريَّةٍة مُتدفقة، فضلَا عن اطلاعهم على التراث، 
وبخاصةٍ التراث الإبداعي الصُّوفي عبر العصور المختلفة، بداية من عصر صدر الإسلام حتى العصر الحديث .

- من أسباب نظم شعراء الأزهر لقصائد ذات نزعة صوفية: ظهور آفاتٍ طرأتْ على المجتمع؛ لعوامل عدة ، فراحوا ينفضون عن الأمة غبار المادية ؛ كي تولي وجهها شطر السماء، مُتضرعين ، مُنيبين ، مُخبتين ؛ فينتقلوا من حالٍ هُمْ عليه إلى حالٍ يسُرٌ الحبيب ويغيظ الأعداء.

- - نظم شعرائُ الأزهر قصائد تَهِيم في المحبَّة الإلهية، وتتغنَّي بالوحدانيَّة، يرجو أصحابها أن يشملهم الله بعفْوه، ويُؤنسهم من وحثتهم ؛ فهم غرباء في دنيا الناس، وعزاؤهم أنهم غرقَّى في الحب الإلهي ، تلفحهم أنوارُ الشوق والحنين ، كما كانتْ لهم كذّلكـ قصائد ذات شعورٍ صادق في المدائح النبوية ، ومعارضة البردة البوصيرية،

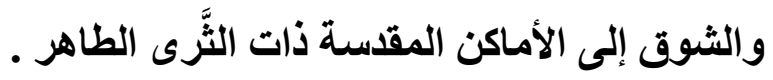
- عمد شعراء الصوفية - ومعهم شعراء الأزهر- الذين أثَّرت فيهم النزعة الصوفية ، إلى الاعوة إلى هذه الأخلاق التي ترتقي بالنفس وتهذبها ؛ كي تتلَّج بها إلى النفس المطمئنة ، وكان على رأس هذه الدعوات: الدعوة إلى العفو والصفح، والزهد والتواضع ، وغيرها من الأخلاق الفاضلة التي يتبنَّاها الخطاب الصوفي في كل عصرِ ومِصنر . - بالوقوف أما المنجز الإبداعي للثعر الأزهري - موضوع الدراسة - نجد أنهم حرصوا- غالبًا على تجلية الفهم الصحيح للإسلام ، دون 
تعصُبِ أو شططٍ أو انحراف ، وهذا هو ديْدن الفكرِ الأزهريِّ الوسطيِّ الأي يتوافق مع صحيح الإسلام وتعاليمه السَّمحة. .

- عندما يُتأمَّل البناء التركيبي عند شعراء الأزهر في قصائدهم ـالتي تجنح نحو النزعة الصوفية ـ يُّحظ أنهم قد تأثَّروا في بعض ألفاظهم بالمعجم الصوفي الذي يحيل المتلقي إلى هذا الجوّ المُفعم بالتبتُّل والخثوع والتجلِّي والخضوع ، كما أفادوا من الأسـاليب المتنوعة التي تعينهم على ما تجيش به خواطرهم ، وما يعتمل في نفوسهم من

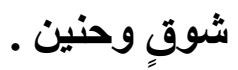
- آثر شعراء هذا الاتجاه مفرداتٍ لُغويَّةٍ خاصة لا يارك كُنهها_غالبًاإلا من يلرك مرامي هذا النوع من الثعر، حتى صارت بعض الكلمات ثابتة في مُعجمهم اللغوي؛ كونهم يرون أن اللغة المألوفة لا تفِي بمرادهم في التعبير عن أُققهم الرَّحب وعالَّهم اللامحدود، فتأتي غالبًا هذه الألفاظ المنتقاة على سبيل المجاز لا الحقيقة ، فاستطاعوا تشكيل نسقِ خطابيٍ مختلف المكونات والمظاهر قادر- بما يحمله من دلالات ـ على التعبير عن الرغبات الجامحة والأثواق الكامنة بين الجوانح .

- - تمتاز معظم القصائد الصوفية لشعراء الأزهر بأنها ذات دلالات

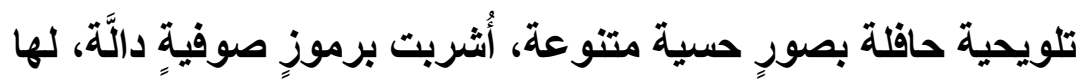

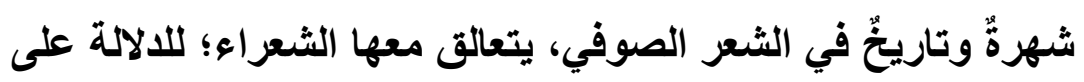
الشوق والحنين؛ اقتداعً بمَن سبقهم من شعراء هذا المضمار ، وكلها رموز متعددة الأبعاد غنية بالدلالات، يتدفق فيها التيار العرفاني الأي 
يحتضن الرمز من خلال نشر هذه الإشراقات الرمزية في رحاب الخطاب الثعري الصوفي في بناء مُحْكِم تتجاوب رموزُه وتتنادَى عناصرهه

- كان للإيقاع- بنوعيه _أثرُ طاغٍ على الخطاب الصوفي في الثعر الأزهري ، كثف عن الانفعال النفسي المُصاحِب للثعراء إبَّان خلق القصيدة ؛ مما أدى لوجود بعض الظواهر التي عملتُ على إضفاء جوٍّ موسيقي مناسب والمضمون الأي يحمله النص،من باية اختيار

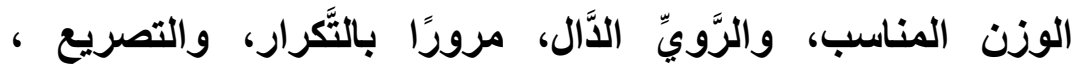
والتقيم،....، إلى إيثار حروفٍ ذات سماتٍ وخصائص معيَّة، ثُقْيد

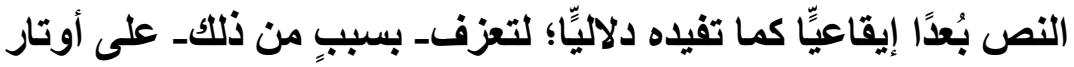
النفس، والأخذ بها إلى معالمَ تُبهجِج النفس، وتوقِظ الحِسَّ ، وتسرٌ القارئين ، بلْه كل متلقي لهذا النوع من الشعر العرفاني الخالص .

كما أوصي نفسي والباحثين بالبناء على هذا البحث ومواصلة مقاربة الثُّعر الأزهري ، وبخاصة في الجانب الصوفي، والوقوف على أعلامه، والتحدُّث عن روَّاده ، والبحث عن روافدهم ومُكوّناتهم الدينية والثقافية ، بما يليق بهم وبأثرهم الجليّ الواضح - من خلال الإبداع الشعري - في التعرف على الخالق - جلَّ وعَلَّ - ، وتوقير النبي الأمين، وآل بيته الأكرمين ، والتأمل في الكون النفس والحياة ، وإنارة الفِكْر القويم

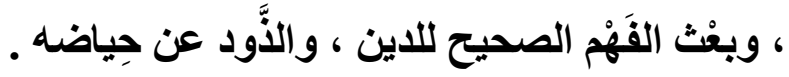
وآخر دعوانا أن الحمد لله رب العالمين . 
ثبث المصادر والمراجع

أولًا : أبرز الدواوين الثعرية

ا. الأعمـال الكاملـة ، هاثـم الرفـاعي المجموعـة الكاملـة، جمع وتحقيق: محمد

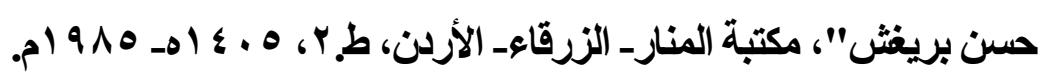

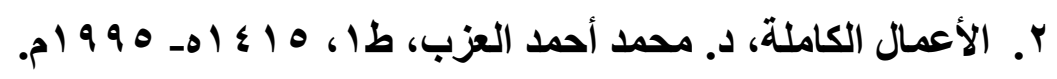

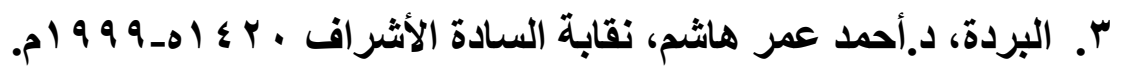
؛. بين الأعاصير، محمد الأسمر ، دار الفكر العربي ، 9 V ام. •. ديوان ابن الفارض، دار صادر- بيروت ، د. ت.

7. ديوان الثعراوي ، جمع ودراسة د. صابر عبد الدايم، الهيئة المصرية

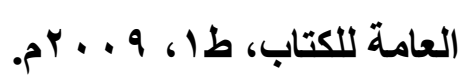
V. شرح البردة للإمام الباجوري ، مكتبة الصفا ـ القاهرة، د. ت .

^. شعر "حسن جاد" جمع وتحقيق ، رسالة ماجستير، محمد عبد الرحمن

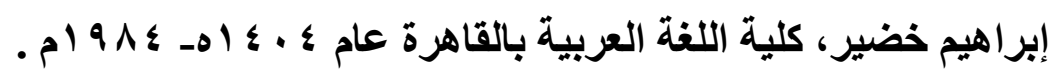
9. الشوقيات ، دار العودة، بيزوت، 1 ، أم.

• . صــى الأيسام ، د. محمـد رجب البيـومي، مطبعـة السـعادة، طץ، . ) $9 \wedge r_{-01 \varepsilon \cdot r}$

11. عبـقُ واسـتلهام، د. عبد الغفــار هـلال، الصـحوة للنشـر والتوزيـع،

$$
\text { ط }
$$


r 1. القافلـة تسـير، د. سـعد ظـلام، المجلس الأعلى لرعايـة القــون

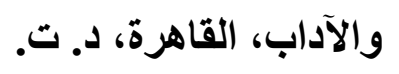

با 1 ـالله أكبر، عبد الله شمس الادين، المجلس الأعلى للشئون الإسلامية، د. ت. ع ا. المسـافر في سنبلات الزمن، د. صـابر عبد الدايم، مطبعة الأمـانة

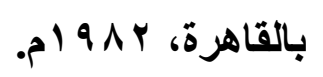

ه . نسـمات إيماتيـة، د. أحمــ عمـر هاثــم ، دار الثـعب ــ القـاهرة ،

$$
.0199 \cdot-01 \leq 11
$$

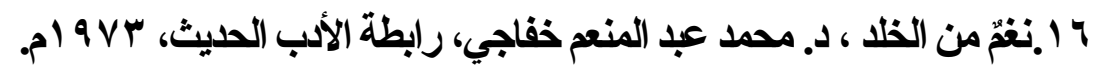

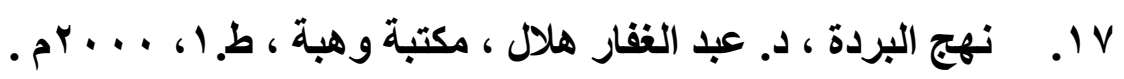

$$
\text { 11 . هاثميات، الثيخ محمود هاثم، طبعة خاصة، د.ت. }
$$

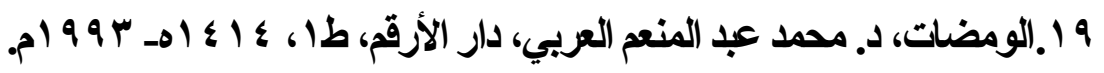

$$
\text { ثانيًّا: أبرز المصادر والمراجع }
$$

ا ـ إحياء علوم الدين للإمام أبي حامد الغزالي، دار المعرفة،بيروت، د.ت . ץ. الأدب الصوفي الإسلامي( اتجاهاته وخصائصسه)، د: صسابر عبد الدايم،

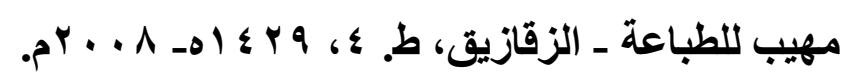

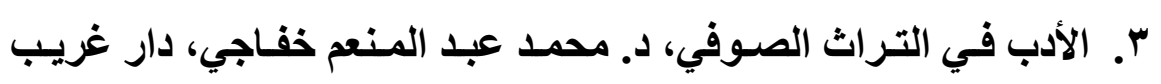

$$
\text { للطباعة ، د. ث. }
$$


ع. الأسـاليب الإنشـائية في النحـو العربـي، عبــ السـلام هـارون، مكتبـة

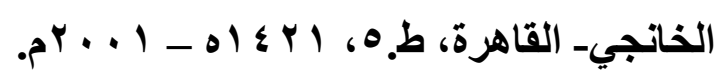

•. الأســلوبية ، بييـر جيـرو، ترجمـة: د. منـــر عياثــي، دار الإنمــاء

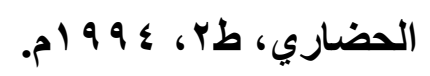

7. الأسـلوبية مدخل نظري ودراسـة تطبيقيـة ، د. فتح الله أحمد سليمان،

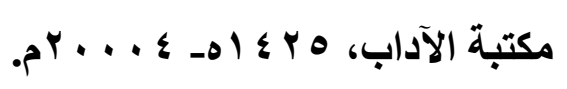

V. الأصوات اللغوية ، د. إبراهيم أنيس، مطبعة نهضة مصر ، د. ت . .

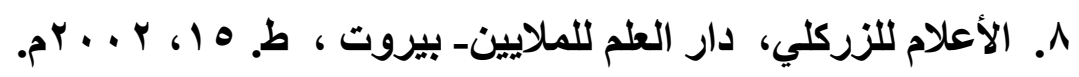

9. تأويل الخطاب الشعري النظرية والتطبيق- محمد أحمد العزب نموذجَا،

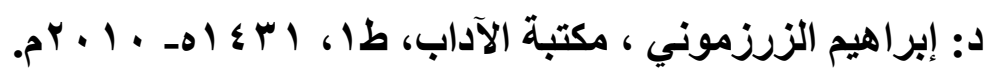

• 1. التصوف الإسلامي في الأدب والأخلاق ، د. زكي مبارك ، مؤسسـة

$$
\text { هنداوي للتعليم والثقافة ، د. ث. }
$$

11. التعرف لمذهب أهل التصوف، لأبي بكر محمد بن أبي إسحاق بن إبراهيم بـن يعقوب الكلابـاذي البخـاري الحنفي ، دار الكتب العلميـة ـ

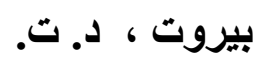

r ا. التعريفات، للجرجاني، دار الكتب العلمية ، بيزوت لـبنـان، ط. 1،

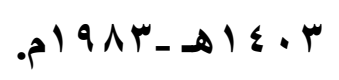

با1. التناص عند شعراء الأزهر في النصف الثاني من القرن العشرين دراسة تحليلية نقديـة ، د. عمر محمد إبراهيم محمد ، رسـالة دكتوراه

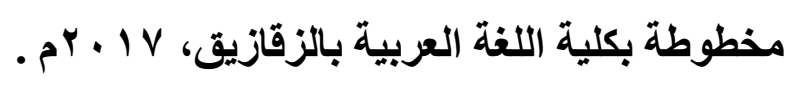


ع ا. الحركـة العلميـة في الأزهـر الثـريف في القـرنين التاسـع عشـر

والعشـرين، د/محمـد عبــ المـنعم خفـاجي، د. علـي صـبح ، المكتبـة

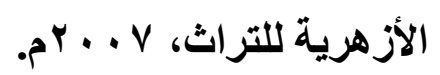

ه . الرسالة القشيرية، لعبد الكريم بن هوازن بن عبد الملك القشيري ، تحقيـق: الإمسام الــكتور عبــ العلـيم محمـود، الـدكتور محمـود بـن الشريف، ج ا، دار المعارف، القاهرة، د.ت. 1 ـ. الرسـالة اللانيـة ، الإمـام أبـو حامـــ الغزالـي ، مطبعـة كردسـتان

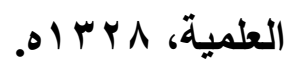

IV . الرمز الشعري عند الصوفية، د. عاطف جودة نصر، دار الأندلس ،

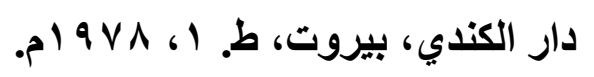

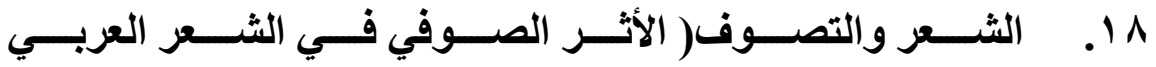

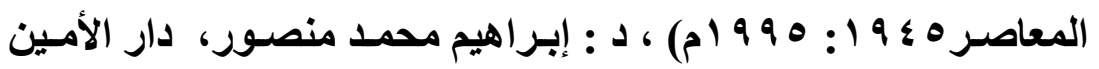

$$
\text { للتشر والتوزيع ، د. ث. }
$$

9 19.الشـعر والشـعراء ، لابـن قتيبة ، تحقيـق: أحمـد محمد شـاكر، دار

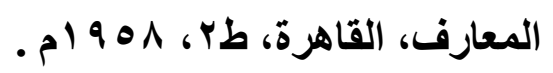

• . . شعـراء كليـة اللغـة العربيـة واتجاهـاتهم الأدبيـة ، د. علـي صـبح، مجلة كلية اللغة العربية ، جامعة الأزهر، بالقاهرة، r I ا ب م .

ا Y. الشكل والخطاب مدخل لتحليل ظاهر اتي ، محمد المساكري ، المركز

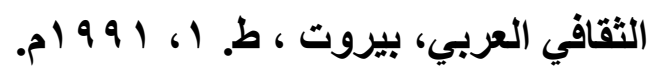

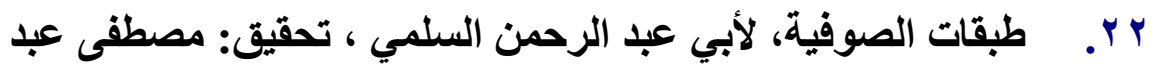

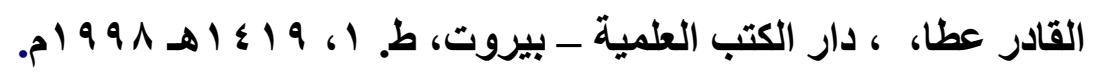




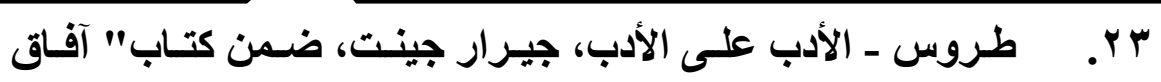
تناصـية" ، ترجمـة: محمــ خيـر البقـاعي ، الهيئة المصـرية العامـة

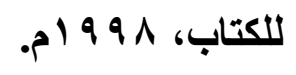

צ Y. عتبات جيرار جينيت من النص إلى المنـاص، عبد الخـالق بلعابد، الار العربية للعلوم ناشرون بيزوت، ودار الاختلاف ـالجزائر، ط. 1،

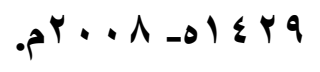

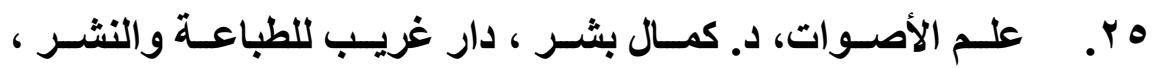

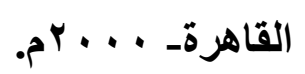

צr. الغـارة المشببوهة على التعليم الأزهري، د. محمـد عمـارة ، دار

$$
\text { المقاصد، طا ، V }
$$

VV

$$
\text { الثيخ: خليل الميس، دار القلم، بيروت ، د.ت. }
$$

^ץ. قوت القلوب في معاملة المحبوب ووصف طريق المريـ إلى مقام التوحيد، جr ، لمحمد بن علي بن عطية الحسارثي، ، تحقيق: عاصم

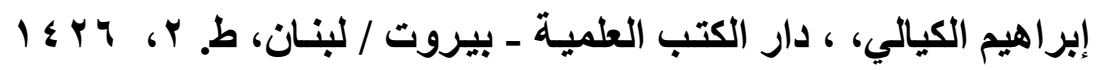

$$
\text { هـ }
$$

q Y. الكشف عن حقيقة التصـوف، محمود عبد الرعوف القاسـم ، دار

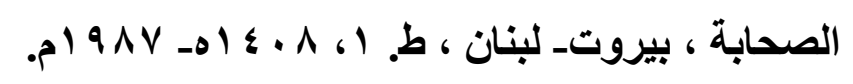

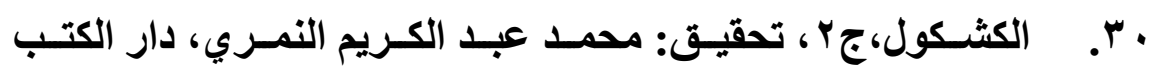

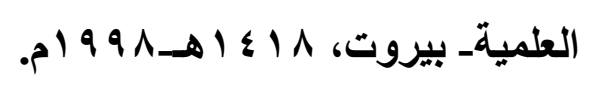




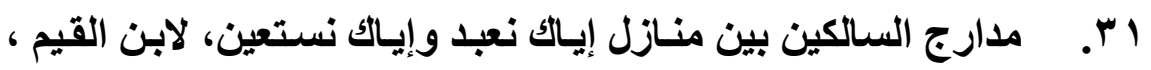

تحقيـق: محمــ المعتصــم بـالله البغـدادي، جY، دار الكتــاب العربـي -

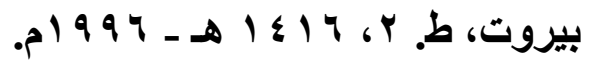

r r r المدهش، لابن الجوزي ، تحقيق: الدكتور مروان قباني، دار الكتب

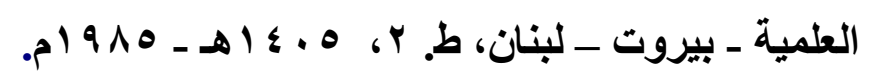

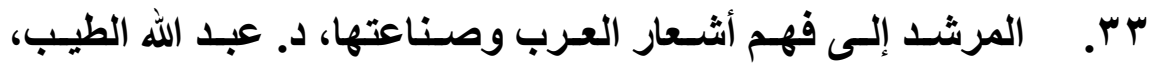

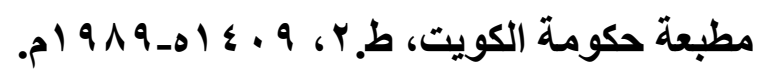

ع ז. معارج القدس في مدراج معرفة النفس، أبو حامد الغزالي، دار

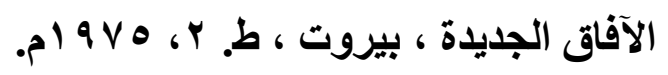

هـ. معجم اللغة العربيـة المعاصرة ، د. أحمد مختـار عمر، ج ا، عـالم

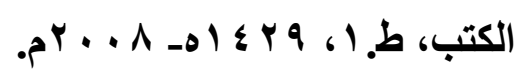

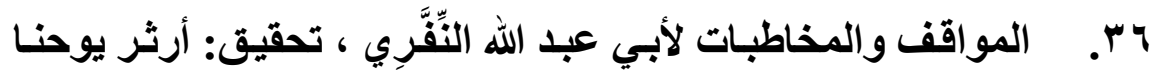

$$
\text { أربري، مكتبة المتتبي بالقاهرة ، د. ت . ل }
$$

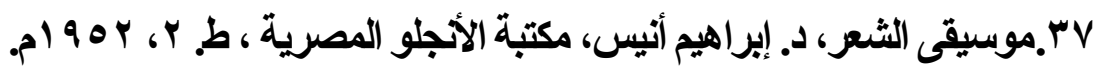

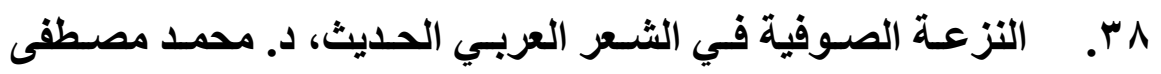

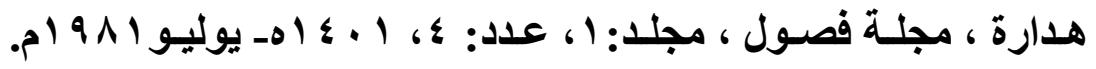




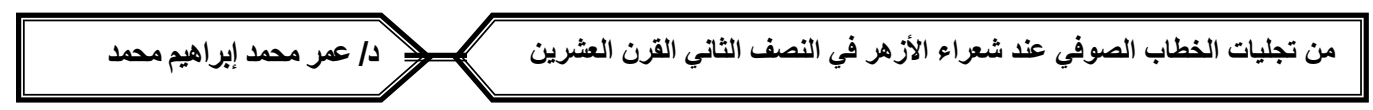

